\title{
THE AMERICAN MEDICAL ASSOCIATION: POWER, PURPOSE, AND POLITICS IN ORGANIZED MEDICINE
}

TABLE OF CONTENTS

I. INtrodtction . . . . . . . . . . . . . . . . . . 938

II. The Adi Structure . . . . . . . . . . . . . . . . 933

A. Membership . . . . . . . . . . . . . . 939

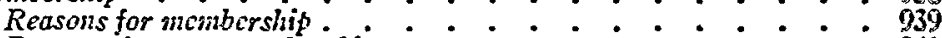

Reasons for non-snembership : . . . . . . . . . . . 941

B. Formal Structure . . . . . . . . . . . . . . . 942

C. Real Poacr Stricture . . . . . . . . . . . . . . 94

III. Sources of Alí Power and Infltence . . . . . . . . . . . 947

A. Pozict over the Profession . . . . . . . . . . . . . . 949

Coszsent . . . . . . . . . . . . . . . . 94

Montopoly . . . . . . . . . . . . . . . . . 919

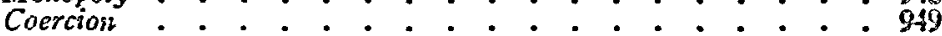

B. The Financial Basis of Poard . . . . . . . . . . . . 953

C. The Political Basis of Poucr . . . . . . . . . . . . . . 934

Prestige • . • • . . • • . . . . . . . 994

Mastery of political tactics . . . . . . . . . . . . 95

Legal recognition . . • • • • • • • . . . . • . . 959

IV. The Aprlication of AMIA Power . . . . . . . . . . . . 959

A. Promoting the Quality of Medical Serrices . . . . . . . . . 959

Screntific actioities . . . . . . . . . . . . . . 959

Post-graduate medical education : . . . . . . . . . . 901

Services to the public . . . . : : . : : : . : . 962

B. Setting the Qualitatice and Quantitutize Standards for Micdical

Practitioncrs . . . . . . . . . . . . . . . . . 903

The campaign against non-medical practitioncrs . . . . . 903

(a) Ouaclss . . . . . . . . . . . . . 963

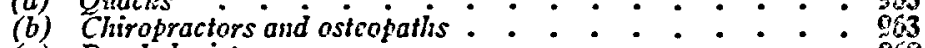

(c) Psychologists . . . . • • . . . . . . . 068

Controlling the quality and supply of doctors. . . . . . . 969

(a) Medical education . : . . . . . . . . . . 970

(b) Licensing of forcignt-trained doctors . . . . . . . . 974

C. Deternining the Conditions of Practice and Paymont . . . . . . 976

Methods of practice . . . . . . . . . . . . . . 977

ITethods of remutherating the pliysician . . . . . . . . . 978

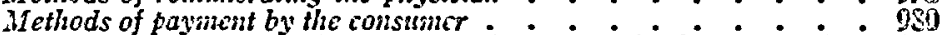

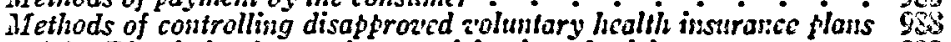

(a) Discrinination against particifating physicions . . . 93

(b) Sponsorship and promotion of competing plans and restrictirc

(c) The struggle against $\dot{H} \dot{P}:$ : : : : : : : : : $: 992$

D. AMA Attitudes tozurd Heallh Mcasures inder Gocernancri Anspices 997

Governmental lczicl of sponsorship and control . . . . . . . 993

Fcderal grants-in-aid for hcalth purposes . . . . . . . . 1000

(a) Grants for hoalth scrices . . . . . . . . . . . 1000

(b) Grants for medical rescarch : . . . . . . . . . 1001

(c) Grants for hospital constriction : . . . . . . . . 1002

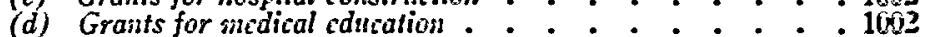

Fedcral health serrices . • . . . . . . . . . . 1004

(a) Unitcd States Public Hcalth Scrive: : : . . : . : 1004

(b) Military and acterans nacdicine . . . . : . . . . 1005

Compulsory health isssurante . . . . . . . . . . . 1007

(a) Dezelopment of a national hicalih program : : . : . : 1007

(b) All.A tactics of opposition. . . . . . . . . . . 1010

V. Linttations on AMA Power . . . . . . . . . . . . . . 1018

VI. Concluston . . . . . . . . . . . . . . . . 1021 


\section{THE AMERICAN MEDICAL ASSOCIATION: POWER, PURPOSE, AND POLITICS IN ORGANIZED MEDICINE}

\section{INTRODUCTION}

IN its hundred-odd years of existence the American Medical Association has attained a position of undeniable authority and influence over medical affairs. The power of organized medicine affects not only the physician but also everyone who requires the assistance of the healing arts. AMA successes in raising the quality of medical education, practice, and care are beyond question. However, in these endeavors it has acquired such power over both public and practitioner that it can channel the development of American medicine. Dangers inherent in such power are compounded by the layman's ignorance of medical matters and the AMA's monopoly position as spokesman for the profession. Out of this situation arise questions of grave significance. The AMA is motivated both by obligations to the public and loyalties to its own members. The demands on it from these two points of view underlie all its activities and suggest the possibility of conflict. To what extent does professional self-restraint, combined with present laws and institutions, assure that this conflict will be resolved in favor of the public interest?

\section{Membership}

\section{The AMA Structure}

The American Medical Association consists of 53 state and territorial (constituent) societies and 1987 county (component) societies. ${ }^{1}$ Each county society sets its own qualifications for membership and its members automatically belong to the state association. ${ }^{2}$ Aside from racial barriers in most southern counties, ${ }^{3}$ all "reputable and ethical" licensed M.D.'s are eligible for

1. AMA, Guide to SERvices 4 (1952). Each component society serves a separate geographical area, and there can be no more than one county society in such an area. E.g., VA. Med. Soc. By-Laws Art. 3, $\$ 2$ (1953). However in some rural areas a local society may cover several counties. E.g., Colo. State Med. Soc. By-Laws c. 11 \& 1 (1951-52).

2. E.g., id. c. 11, §5. Some county societies in Kansas admit "associate members" although the state society will not recognize them as members. RePLY to QUESTIONNAIRE, Kansas Medical Society, Question No. 10. (Hereinafter cited as Questionnaike No. - A comprehensive questionnaire was sent to the 48 state medical societies and to the Medical Society of the District of Columbia. The following twenty-four fairly representative societies responded in varying degrees of detail to the 83 questions: Alabama, Arkansas, California, Colorado, Connecticut, Florida, Illinois, Iowa, Kansas, Louisiana, Maine, Massachusetts, Missouri, Montana, New Hampshire, New Mexico, Pennsylvania, South Dakota, Texas, Utah, Vermont, Virginia, Washington, and West Virginia. The original answers from each society and a compilation of all the answers given to each question are on file in the Yale Law Library.)

3. See note 22 infra. 
membership. ${ }^{4}$ And in most areas virtually every practicing physician belongs to his local society. ${ }^{5}$ Until recently, all members of county and state medical societies were also automatically members of the national association. But in 1950 payment of dues, previously assessed only by the county and state groups, became a prerequisite to AMA membership. ${ }^{3}$ Now some physicians belong only to their county and state societies, and are not members of the American Medical Association. ${ }^{7}$ On the other hand, since belonging to a county society is a prerequisite to admission at all levels, membership in the AMA depends upon acceptance by the local organization.

Reasons for membership. Many factors contribute to the high percentage of physician membership in organized medicine-a proportion unique among

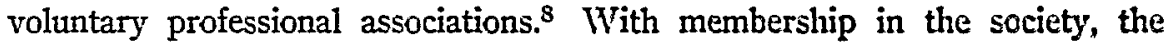
doctor receives ready access to the social and professional contacts indispensable to the growth of his practice-contacts which may lead to patient referrals and consultations. ${ }^{9}$ Additionally, there is the all-important factor of association with men engaged in his own science, with opportunities for exchange of knowledge and acquisition of professional status. The medical societies disseminate the latest scientific information through professional journals which are available to members either at no cost or at reduced rates, and through lectures, exhibits, and medical libraries which the societies support. In addition to these professional services, the local and state societies aid members by providing group malpractice insurance, ${ }^{10}$ and by offering legal advice. ${ }^{11}$ Many of the larger societies maintain bill collection agencies. ${ }^{12}$

4. Many county societies impose additional requirements upon applicants for membarship: e.g., they must be graduates of an AMA approved medical school, United States citizens, present medical practitioners within the county, and practitioners of non-sectarian medicine. QuestionnaIse No. 9.

5. QUESTIONNAIRE No. 5. Half of the societies report over $90 \%$ membership among eligible, active physicians in their states. Only two states-Pennsylvania and Washington-report two-thirds membership or less.

6. See text at note 656 infra.

7. The AMIA claims a membership of over 140,000. Ir's Yous AMA [1] (1953). Although in one society-New Hampshire-less than $00, \mathrm{C}$ of the state socicty membars pay dues to the AMIA, more typically $95 \%$ to $99 \%$ are AMIA members. Questro:z:sares No. 8. And in Illinois, the Society's constitution and by-laws require all members to pay AMIA dues. Illitiois QuestionNaIRE No. 8.

S. How the Doctors Solved the Coordistation Problem, 21 A.B.A.J. 221, 223 (1935).

9. See Group Health Cooperative of Puget Sound v. King County Ifedical Society, 39 Wash.2d 586, 626, 237 P.2d 737, 759 (1951); Gancenu, Tne PuLuticll Life af TuE AxIERICan Mídical Assoctation 103 (1941) (hereinafter cited as Gubienc).

10. A 1950 survey showed $35 \%$ of the county societies maintaining grapp malpractice insurance for their members. AMA, Actrvities of Covinty Ifeorcil Socreties 6, 7 (1951). Three state sacieties reporting now offer this insurance to their members and twe others formerly did so. Questionname No. 55.

11. See, e.g., You and the Mrdical Society of the State of New York 14 (1952) (legal defense provided for members involvcd in malpractice suits).

12. Seven percent of the county societies responding to an AMA questiunnaire hod

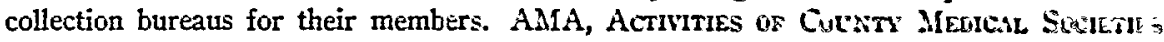
6,7 (1951). 
There may also be direct economic benefits incident to membership. Since the societies often contract to furnish medical care to indigents ${ }^{13}$ and veterans, ${ }^{14}$ participating physicians have a supplementary source of income from these programs. Membership can also be a conduit to such professional advancements as hospital staff appointments, ${ }^{15}$ teaching positions, ${ }^{10}$ and specialty ratings. ${ }^{17}$

Beyond the advantages which accrue to the member physicians, there are services which the society renders to the profession as a whole. The AMA has improved curricula and facilities in American medical schools. It gives financial support to research projects and publicizes medical discoveries through its journals and meetings. Moreover, many doctors look to the American Medical Association to protect their interests against encroachment. Thus, the AMA spearheaded the drive against compulsory health insurance and other governmental inroads into private medical practice. And the Association has worked to rid the profession of quacks, as well as licensed physicians thought guilty of malpractice, and to limit the activities of non-medical practitioners. Since the entire profession profits by these efforts of the AMA, physicians may feel obligated to join and give their material and moral support.18

13. In Iowa the county societies conduct indigent patient clinics and in four other societies membership is a prerequisite to physician participation. QUEsTronNaIRE No. 54(c) ; Iowa State Medical Soctety, Handbook for the House of Dexegates 20-44 (1950) (county societies reporting upon relief contracts held with local Boards of Supervisors). See, generally, IStern, Medical Services by Governument 23-6 (1946).

14. Iowa State Medical Soctety, Handbook for the House of Delegates 55 (1950) (reporting contract with Veterans Administration to furnish medical care in veterans hospitals); You aNd the Medrcal Society of the STATE of NEw Yonk 53 (1952) (reporting fee schedule negotiations with the Veterans Administration for physicians serving veterans).

15. See notes $93-5$ infra and accompanying text. See also Group Health Cooperative of Puget Sound v. King County Medical Society, 39 Wash.2d 586, 620, 623-5, 237 P.2d 737, 755-6, 757-8 (1951).

16. E.g., in Illinois, Kansas, and Pennsylvania. Questionnalre No. 54(a). Hcarings before Senate Committee on Education and Labor on S. 1606, 79th Cong., 2d Sess. 2642 (1946) (non-members of the Chicago Medical Society ineligible for staff membership of teaching or research institutions). But see text at note 23 infra.

17. "We [non-society members] cannot be accredited by various specialty boards because membership in the local medical society is a condition of eligibility. This is an increasingly serious handicap, since many hospitals are making certification by a specialty board an absolute condition for practicing within those hospitals." Testimony of Lawrence Jacques, M.D., in Hearings, supra note 16, at 2642. See also Group Health Cooperative of Puget Sound v. King County Medical Society, 39 Wash.2d 586, 626, 237 P.2d 737, 759 (1951).

18. The AMA and the state societies solicit support by emphasizing their contributions to the profession. See, e.g., Ir's Your AMA [1] (1953): "We can take great pride in our AMA. It is the largest, most influential and most active medical association in the world. Even if you are not a member, it is your AMA to a certain extent. The Association began helping you the day you entered medical school and continues to aid your practice and guard your freedom. Though, for one reason or another, you do not share the responsibilities of membership, you benefit daily from the Association's work." See also You AND TriE 
Reasons for non-membership. However, a substantial number of American doctors do not belong to the American Medical Association or its component units. ${ }^{19}$ Many of these are retired physicians who let their membership lapse, or young practitioners who have not yet fulfilled the residence requirements for their local society. 90 Doctors who do not conform to the code of medical ethics are not eligible for membership. ${ }^{21}$ And many southern societies exclude Negro physicians.2.2 Salaried doctors, such as those on the staffs of

Miedical Society of the State of New Yosx 4 (1952) ("The freedom with which yeu practice and your very livelihood would be seriously jeopardized if the physicians of New: York were not organized into a state-wide association.").

19. Of the 215,000 licensed physicians in the United States, Wondo Alssarise 779 (1954), about 140,000 are AMA members. Supra note 7 . Some non-AMA members belong to local and state societies. Supra note 5.

20. Questronnaire No. 5. Connecticut, for example, has a one-year recidence requirement, and reports a corresponding lag in admitting physicians newly arrived in the state.

21. Eg., Tex. Mied. Ass'v Const. Art. 1, \& 3 (1952).

22. The majority of county medical societies in the southern states deny membsrship to Negro physicians. Of those southern societies responding to the Questionnaire, four report no Negro members. Alabania, Loluslana, Texas, Virginia Question:iales Nu.

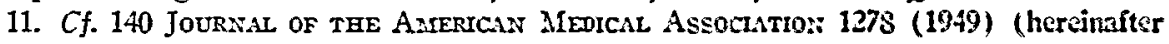
cited as JAMA).

The unsegregated National Medical Association is the organization to which most Negro physicians belong. In 1870 the AXIA House of Delegates refused to accredit the NMIA as a constituent society. Cobe, The Frrst Negro Mienrcal Socrery c. 2 (1939). In rejecting the NMA's then tiny membership the AMA established a policy, since written into the by-laws of many state societies, of one component society only in a given gexgraphical area. E.g., VA. MEp. Soc. By-LAws Art. 3, $\$ 2$ (1953). Members of the colored Medico-Chirurgical Society of the District of Columbia, for example, cannot bscome AMA members through their present organization since, as the component society for that territory, the District of Columbia Mfedical Society fills the field.

There have been some signs of progress in the eradication of racial barriers on the local level. Recently, previously exclusionary local societies in the District of Columbia, Florida, and Missouri have admitted Negro members. Cannon, Why I am a Alcmler of the Physicians Form, Physicians Forum Eull., Sept, 1951, p. 10. See also Arra:isas, Flosida, Missocri Questionnaine No. 11 (reporting some Negro memters). In 19:0, New York sent the first colored member, Dr. Peter MIurray, to the AAIA House of Delegates. $140 \mathrm{JAMI}$ A 1278 (1949). Dr. Mrurray has since been elected to office in the New York County Medical Society. N.Y. Times, MIay 27, 1952, p. 29, col. 4 (Vice-President); id., May 26, 1953, p. 31, col. 8 (President-Elect). And members of the NMIA have attended AMA's county, state, and national scientific sessions, and NMA "observers" have been invited to AMIA conventions. See, c.g., 140 JAMIA 1278 (1949).

But the AMA as a national organization has failed to tale steps toward a fundamental change in membership policy. Its spokesmen assert thuir inability to act, puinting out that each county society has absolute control over its own membership qualifieations. Cannon, supra at 9; Chicago Tribune, May 19, 1939 (Editorial). Huwever, a group of New York physicians obtained State Society approval of a resolution froviding that "ny constituent association shall exclude from membership any physician for other than fris= fessional or ethical reasons." The resolutions failed in the A.1A Huuse of Delegates. Medicine: White or Black, 68 School \& Soctern 70 (1948). Similarly the Mcdinal Society of North Carolina made an unsuccessful attempt to challenge the one componsnt 
universities and research institutes, and civil servants often do not join medical societies $;^{23}$ here professional advancement is available through channels other than medical society membership. In remote areas services which the society can render may be so negligible that doctors have little incentive to join. ${ }^{24}$ Some physicians may find the dues prohibitive; for example, in parts of California the total of county, state, and national dues runs as high as $\$ 190$ annually. ${ }^{25}$ Undoubtedly some doctors do not join because of apathy, ${ }^{20}$ while a small minority of physicians do not choose to belong because they disapprove of the policies of the AMA. ${ }^{27}$

\section{Formal structure}

The formal structure of the American Medical Association provides for the largest measure of direct democratic control in the county medical societies, and increasingly indirect representation at the state and national levels. Members vote directly for county officials and representatives to the state "legislature," usually known as the House of Delegates. ${ }^{28}$ These delegates select their own state officers and elect the state representatives to the national

society geographical rule when it proposed admittance of the colored Old North State Medical Society as a constituent organization. 147 JAMA 1241 (1951); 150 JAMA 1684 (1952).

The AMA has, however, deemed it politic to court colored non-member doctors for support in its opposition to compulsory health insurance. At the 1950 NMA convention, an AMA representative cited Dr. Murray's election to the House of Delegates as an indication of equality in medicine. Cannon, supra at 9. The NMA, seeking the full benefit of AMA membership for all colored physicians, treated AMA overtures with caution. It avoided the endorsement of either the AMA's or the Truman Administration's position on health insurance, perhaps hoping that its strength of 4000 members might be a bargaining lever to gain full affiliation. Time, Aug. 22, 1949, p. 32. But with the compulsory health insurance issue at least temporarily mooted, the southern colored physician will have to look for a change of heart from within the AMA before he can expect full equality with his white colleague.

23. Question NaIre No. 5; Garceau 105.

24. Cf. West Virginia QUeStTonnaire No. 5.

25. Calmfornia Questionnarre Nos. 12, 13. Several societies mention inability to pay dues as a cause of non-membership. QUestionNaIre No. 5. Other socicties mitigate the dues requirement in cases of financial hardships. See, e.g., Colo. State Med. Soc. By-Laws c. 1, § 5a (1951-52); W. VA. State MED. Ass'n By-Laws c. 1, § 5 (1952).

The range of county society dues within a state may be wide. E.g., Texas: $\$ 1$ to $\$ 100$; California: $\$ 5$ to $\$ 125$. Questionnarre No. 13 . And state society dues vary from $\$ 15$ to $\$ 55$ a year; the average is about $\$ 25$. QUESTIONNAIRE No. 12.

The AMA assesses its members $\$ 25$ for annual dues. AMA, Guide to Services 10 (1952). However it grants exemptions for the following reasons: financial hardship, retirement from practice or reaching the age of 70 , internship or residency with five years of graduation. Id. at 17.

26. Questionnatre No. 5.

27. See, e.g., Dr. J. H. Means resigns from AMA to protest levy to fight Fedcral insurance, N.Y. Times, June 22, 1951, p. 14, col. 4.

28. Each county society is entitled to at least one delegate although representation in state Houses is generally proportional to membership in the local society. Apportionment 
House of Delegates. ${ }^{29}$ This body elects the President and other AMA officers and the nine-man Board of Trustees. ${ }^{30}$

In theory, the policy-making function of the American Medical Association is vested in the House of Delegates. However, since the House meets semiannually, many administrative and policy decisions are necessarily left to the Board of Trustees. ${ }^{31}$ Although it is responsible to the House of Delegates, the Board functions with little supervision when the House is not in session. The members of the Board perform the typical role of corporate directors: they approve all AMA expenditures, and generally the Chiefs of the Association's operating bureaus are responsible to them. ${ }^{32}$ The Trustees also appoint the Secretary-General Manager ${ }^{33}$ and the Editor of the Journal. President has little formal power in formulating AMIA policy, although he enjoys tremendous prestige as chief spokesman for the organization. ${ }^{35}$

The AMA functions through standing committees or councils elected by

ratios vary among the societies from one delegate for every ten members to one for every hundred; the average representation is one delegate for every twenty-five members. Questionnaike No. 19. Densely populated areas tend to be under-representcd. E.g., in New York, Schuyler County has one delegate for its eleven members, while New Yorl: County (Manhattan) has only 24 delegates representing its 6954 members. Kings County (Brooklyn) also has 24 delegates for 3467 members. You AND tHE MEDICAL SOCIET: of THE STATE OF NEw YoRk 32 (1952).

29. An AMA delegate's term is two years. State societies are represented by one delegate for every thousand members or fraction thereof. A representative from the Army, Navy, Air Force, Veterans Administration and U. S. Public Health Service, and twenty representatives from the specialized medical fields within the AMA also serve in the House. AMIA By-LAws c. 9, \$ 1(B) (1952).

30. The President, President-Elect, Vice-President, and other AMA officers are elected annually. The President and President-Elect serve on the Board of Trustees. The other Trustees are chosen for staggered five-year terms and may serve not more than two successive terms. IT's Your AMA 3 (1953).

31. Ibid. The Trustees meet six or eight times a year.

32. AMA By-Laws c. 13, $\S 4(A)$ (1952). The powers of the AAIA Bourd of Trustees are duplicated on the state level. E.g., the Texas Board of Trustees serves "as a board of directors, within the meaning of the corporate laws of the state." TEx. MED. Ass'in Const. Art. 4 (1952).

33. AMA By-LAws, c. 13, $\S 4$ (D) (1952). After he is appointed General Mlanager by the Trustees, he is elected Secretary by the House of Delegates. Unlike the officers and Trustees, he is a salaried employee. Ir's Your AMIA 3 (1953).

34. AMA By-LAws c. $13, \S \mathcal{H}(\mathrm{C})$ (1952). Until recently the Editor of the Journal was the dominant figure in the Association. Mayer, The Rise and Fall of Dr. Fishbcist, Harper's, Nov., 1949, p. 199.

35. The President's official duties consist largely of addressing the House of Delegates and nominating members for various committees, subject to confirmation by the House or Trustees. AMIA By-Laws c. $12, \S 1$ (1952). Prior to his term of office, the President serves as President-Elect for one year, during which time he presides over the General Sessions and Council of the Scientific Assembly. AlA Co:sr. Art. 7, \& 3; AMA By-Laws c. 12, $\$ 2$ (1952). However, the President's Page in the Joumal and his frequent appearances before Congressional Committees increase the President's importance as "chief spokesman for the Association on policy matters." Ir's Yorr AMA 3 (1953). 
the House of Delegates or appointed by the Board of Trustees. ${ }^{30}$ Each council directs the activities of the Association in a particular field with the assistance of a full-time staff. The 900 employees of the national organization are supervised by the Secretary-General Manager of the Association, who has chief responsibility for the day-to-day decisions of the organization between meetings of the Board of Trustees.

\section{Real power structure}

While democratic procedures exist at the county level, ${ }^{37}$ many members do not have sufficient interest in activities to attend meetings. ${ }^{38}$ Doctors are extremely busy with their practice and have little time to devote to the problems of organized medicine. In New York, for example, $25 \%$ attendance at a business meeting is considered good. ${ }^{30}$ Thus, the few doctors who are interested in medical politics can easily wield power and influence out of proportion to their numerical strength.

The nominating process for elections within the American Medical Association allows the officers in power to have the dominant influence in deciding who shall succeed them in office. At the county level, the President appoints a nominating committee which puts up a slate of officers and delegates for the state House of Delegates. ${ }^{40}$ The state President functions in the same way in the selection of national delegates. ${ }^{41}$ These elections are rarely con-

36. For a general description of the AMA's operational structure, see I $T$ 's Youk AMA 1-6 (1953) ; AMA, GuTdE to Services 8-9 (1952).

37. See, however, AMA, Putting PR to Work 13 (1st Public Relations Institute 1952) : "You would be surprised how many county societies do not even have a semblance of democracy in their sessions." (statement of county society official).

38. The results of an AMA survey showed that urban county societies had the lowest average attendance at meetings. Sixty of 64 societies with more than 300 members report attendance of under $50 \%$, while only 48 of 581 societies having less than 100 members were in this category. And 111 of the smaller societies report $90-100 \%$ attendance. AMA, Activities or County Medical Societres 3 (1951). Although the AMA regards thesc results as indicative of generally good attendance at local meetings, a former AMA President has remarked that "if $10 \%$ of the membership [in many areas] attend a mecting it is about average and it is usually the same $10 \%$ at each meeting." BAUER, THE IMrORTANC: of the County Medical Society in the State and National Prograxis (address before the Medical Society of the State of New York, January 27, 1947) (copy on file in Yale Law Library).

County societies list as their best attended meetings those featuring specches on general medical subjects by "well known" and "respected" members of the medical profession. Meetings on socio-economic problems are ranked as poorly attended, "despite the increased interest in ... [these] problems by members of the medical profession during the past few years." AMA, Activities of Countr Medical Societies 4 (1951).

39. Richardson, Freedom of Speech and Organized Medicine 4 (undated typewritten manuscript on file with Physicians Forum, 510 Madison Ave., New York City).

40. E.g., Pennsylvania Questionnaire No. 18. In Virginia the county President alone chooses some of the delegates to the State House. Virginia Questionnaire No. 18.

41. E.g., Kans. MEd. Soc. By-Laws c. 6, § 1 (1952) (Nominating Committec for the selection of state society officers composed of five former Society Presidents); Colo. 
tested. ${ }^{42}$ In at least one state, Alabama, the delegates are appointed by the President. ${ }^{43}$ The election of the official slate is made easier by the fact that the state and national organizations forbid electioneering and soliciting rotes for office. ${ }^{44}$ Even where the official slate offers alternative nominees, basic differences between the candidates are unlikely. ${ }^{25}$

The nominating process, in combination with the apathy of the average doctor, ${ }^{49}$ assures domination by a single faction within the A.M.1.4T In New York-one of the few states where an organized opposition has developed-these challengers have had little success.4 State societies report that reelection of delegates is common, ${ }^{40}$ the same names appearing on the ballot year after year. Frequently officers progress steadily from county, to state, to national prominence as they acquire seniority. ${ }^{50}$

State Med. Soc. By-Laws c. 6, $\$ 1$ (1951-52) (nominations from the floor permittcd); Connectictt Questionnaire No. 20 (same).

All state society delegates to the AMA House must nicet the AMA constitutional requirements of two years' prior membership in the AMA and its Scientific Assembly. AliA BY-Laws c. 9, \$1(A) (1952).

42. QuestronnarRe No. 21 (only four of 24 state societies report competition for position of AMA delegate). Kansas requires Nominating Committees to prescnt two nominees for each delegate position. Kuxs Mfen. Soc. By-Laws c. 6, \$1 (1952).

43. Alabana Questionnaine No. 20.

44. E.g., Kaxs. Med. Soc. By-Laws c. 6. $\$ 4$ (1952) : AMIA House of Delegates Standing Rule, adopted June 13, 1902: "Resolved that it is the sense of the House of Delegates of the AMA that the solicitation of votes for office is not in lieeping with the dignity of the medical profession, nor in harmony with the spirit of this Association, and that such solicitation shall be considered a disqualification for election to any offee in the gift of the Association." Although the Judicial Council has stated that this rule, as phrascd, was unenforceable, Fisheers, A History of the Asierican Merical Assoclitio: 419-20 (1947) (hereinafter cited as FisHBeIx), it was found to be an "effective moral influence," ibid, and it has never been repealed. Id. at 224 .

45. RICBARDSON, op cit. supra note 39, at 3-4.

46. The inertia of the majority of AMA members has been attributed to the consuming nature of medicine, the drive toward material success, and an aversion against "p plitics." GaRCEAU 61-3. Consequently the membership is said to turn to the AMA, thus saving itself from the "awkward predicament of having to thinl:" Id. at 101.

47. RichaRdson, op. cit. sipra note 39, at 4.

48. The Physicians Forum was organized in 1941 by members of the Medical Society of the County of New York to defeat a proposed amendment to the state society constitution. This amendment provided that members "shall not initiate or participate in any" activities outside the structure of the Medical Society of the State of New Yorl, which are contrary to [its] policies. . . " Chapters have been formed in other cities and the group has promoted health insurance and other measures counter to "official AMA destrine." 12 N.Y. JIEDICINE, Nov. 20, 1952, p. 13 (letter from Ernst P. Boas, MI.D., chairman of Physicians Forum). Although the Forum was successful in defeating the amendment and in electing "several liberal minded physicians" to county officerships, its influence was of short duration. RICEARDSON, op. cit. supra note 39, at 16.

49. Several societies report that all delegates are re-electcd while ollicrs estimate that between one-third and one-half of the delegates are rechosen. One renlied that "receptive delegates" are re-elected and another characterized the tenure of delegates as extending "until they choose to retire." Only three indicated that few or no delegates were "repeaters." QUEstionNaiRe No. 23.

50. An example of "devotion to medical society office" is the career of former AMA 
One of the major obstacles to the formation of any opposition is the lack of an effective forum for dissident opinion. The Journal of the American Medical Association, which is the publication most widely read by members, rarely prints opinions in disagreement with positions taken by the House of Delegates or Board of Trustees. ${ }^{51}$ In response to criticism of this policy the American Medical Association asserts that members can present their views initially in their county societies; that if these views win approval, delegates will present them to the state society, and finally the members' opinions will be presented to the national House of Delegates for consideration. ${ }^{52}$ In practice, however, because of the indirect system of elections, ${ }^{63}$ such a procedure eliminates any dissident viewpoints above the county level unless they win majority support. And while a member can oppose official policy in his local society, the structure of organized medicine makes it almost impossible for him to effectuate his opinions within this framework. ${ }^{54}$

One study of the American Medical Association has concluded that the physicians who rise to power within the medical societies are predominantly urban practitioners and specialists. ${ }^{55}$ Although there is only a slightly larger

President Rock Sleyster who served as Secretary of his county society, Secretary, President, Treasurer, and Editor of the Wisconsin Society, Delegate and Vice-Speaker of the AMA House, and member and Chairman of the Board of Trustees. Garcenu 59. For further illustrations see $i d$. at 58-61.

The "active physician" in the New York Society proceeds from membership in a standing committee to its chairmanship. The second vice-president, who automatically becomes President within a few years, is chosen from such members. RICHARDSON, $o p$. cit. supra note 39 , at 3 .

51. Davis, America Organizes Medicine 175-6 (1941); Medical Economics, July, 1952, p. 12. Spokesmen have emphasized their desire that organized medicine present a united front. See, e.g., 111 JAMA 936 (1938) ("Once the House of Delegates has spoken its actions should be supported by the united voice of American medicinc.") ; 49 N.Y. State J. of MEd. 2527 (1949); cf. 139 JAMA 788 (1949). Perhaps the Journal's practice is a result of this attitude. However, this policy has been widely criticized. Sce 1 N.Y. Medicine, Aug. 20, 1945, p. 11 (editorial advising that "some further consideration ... be given to [the Journal's] policy with reference to publication of dissident opinions and views.") ; 244 N. ENG. J. of MED. 307 (1951) (reporting resolution of Mass. Medical Society urging "that the Journal of the American Medical Association welcome and provide space for the presentation of considered discussion from varying points of view. ..."). Cf. N.Y. Times, Nov. 30, 1952, p. 54, col. 3 (Editor of Atlantic Monthly criticizing Journal's refusal to accept paid advertisement of article on compulsory health insurance).

State society journals have been similarly criticized. DAvis, op. cit. SUpra; GaRCEAU $100 ; 27$ J. of Pediatrics 196 (1945). However, there are some exceptions. The Ncw England Journal of Medicine maintains that its columns are open to comment critical of the official AMA position and has published divergent viewpoints. 240 N. ENG. J. of MED. 397 (1949).

52. 149 JAMA 1227 (1952). But see 5 N.Y. Medrcine, March 5, 1949, p. 41 (county society member describing his inability to have his views heard); note 37 supra.

53. See text at note 40 et seq. supra.

54. But cf. 149 JAMA 1227 (1952) (example of individual member's securing passage of previously unconsidered resolution concerning physical selection of airplane pilots without prior official support).

55. Garceau 55-8. 
number of specialists in the United States than general practitioners, ${ }^{50}$ usually over $90 \%$ of the officers of the AMIA are specialists. ${ }^{57}$ Specialists, whose incomes are above those of the average practitioner, ${ }^{68}$ are probably better able to devote time to medical politics. Statistics also reveal that cities contribute a larger proportion of officers than rural areas. ${ }^{59}$ And in the AMA House of Delegates those who have served long terms are primarily from urban localities, while the shorter term delegates tend to be from the rural areas. ${ }^{c 0}$

Although these officers are not "average" American doctors, it would not be accurate to say that their policies are unrepresentative. The support of the membership is clearly shown in the immediate response of most members to a voluntary assessment voted by the House of Delegates. ${ }^{01}$ MLost members also seem willing to distribute literature and advocate AMA policies. ${ }^{62}$ But perhaps the most indicative fact is that groups organized to oppose AMA policies regarding the economic and political aspects of medical practice have never gained widespread support among the doctors. No group of any significance that has been formed to modify or review AMA policy has offered itself as an alternative to the AMIA. Doctors are free to join such organizations while retaining their AMIA membership but few have enrolled. ${ }^{63}$ Even though the actively controlling group within the American Miedical Association is a self-perpetuating minority its viewpoint is readily accepted by the passive majority. This acquiescence assists that governing minority in excluding dissident opinion from organized medicine.

\section{Sources of AMA Power and Influence}

The essence of AMA strength is found in its power over the medical profession, its economic position, and the status of the doctor in society. More-

56. There were, in 1949 , approximately 72,500 physicians exclusively in general practice, 55,000 exclusively practicing a speciality, and 23,000 general practitioners "giving attention" to a specialty. 3 Presment's Commrission ox the Heurtu Nerns of the Natro:, Bunding Adierica's HeAlth 140 (1952-53) (hereinafter cited as Mingsuso: Rer.).

57. All but one of the present members of the Board of Trustees and all A.IA Precidents, Vice-Presidents, and Speakers since 1947 have been specialists. Compilation on file in Yale Law Library.

58. 4 Migatuson Rep. 247.

59. Only seven of 31 recent and present high officers and Trustees of the AMA practice in communities of 25,000 population or less. Compilation on file in Yale Law Library.

60. Garceau 50 .

61. Only one state society indicated that less than $50 \%$ of its membership paid the 1948 assessment. And 14 societies reported that from $00 \%$ to $98 \%$ of their member contributed. Questionisine No. 15. See also note 641 infra.

62. See text at notes $642-8$ infra.

63. Thus, the Committee of Physicians for the Improvement of Mfedical Care has functioned within the AMIA with about 700 members. Jinu:s, Doctuns, PEorLE, n:io Governarent 147-50 (1953); Davis, Ayerica Orgunizes Minorcine 393 (1941). The Physicians Forum is open only to members of county societies or the National Mredical Association, 12 N.Y. MEmIciNe, Nov. 20, 1952, p. 12, and has never drawn much support. See note 48 supra. 
over, due to the character of its membership, organized medicine probably has a greater potential influence than organizations of other professions. And it has capitalized upon its latent strength by a skillful application of all the resources at its disposal.

\section{Power over the profession}

Consent. Fundamental to medical practice is the concept of professionalism. ${ }^{64}$ Practitioners are bound by a common interest in increasing the effectiveness and maintaining the integrity and prestige of the profession. This derives from recognition of a duty toward the public, as well as a desire to benefit individual members. In addition, problems and affairs of medical practice are assumed to be beyond the comprehension of the layman. ${ }^{05}$ So, in order to realize its objectives, the profession must govern itself through an effective organization. The American Medical Association fulfills this function and enjoys the consent and loyalty of an overwhelming majority of physicians. Even potential dissenters may remain silent in the belief that the interest of the profession is best served by presenting a united front to the public. ${ }^{80}$

Monopoly. This consent has enabled the AMA to attain a monopoly position within the profession. Doctors may believe rivalry between competing professional associations would be injurious to both public and practitioner. Consequently, other medical groups formed to fulfill specific needs have tended to cooperate or affiliate with the AMA. And until recently there was almost no disagreement within the profession concerning its proper interests. ${ }^{07}$ So the small minority which would today challenge AMA authority is confronted with an organization that has already built its position into one of "natural" monopoly.

No independent medical association provides the doctor with an alternative to membership in his local medical society. In the scientific realm there are such groups as the American College of Physicians, the American College of Surgeons, and organizations representing the recognized specialties. In the field of medical economics and politics the Committee of Physicians for the Improvement of Medical Care and the Physicians Forum actively oppose AMA policies. And the National Medical Association, composed of Negro physicians, is concerned with the problems of a minority group and seeks constituent membership within the AMA.68 These groups, whose members are usually AMA members as well, supplement its work or compete with it only in a limited sphere. None possesses the membership size, power, and influence of the AMA, nor can any challenge its claim to speak on behalf of the profession.

64. See generally, Garceau 5-12.

65. Id. at 5 .

66. See note 51 infra. See also FishberN 392; Ir's Your AMA 41 (1953); 149 JAMA 843 (1952).

67. Fishbein reports only minor disputes. Fishbein 144, 390, 395-6.

68. See note 22 supra. The NMA's membership is 4000 . Wordd Alaransc 495 (1954). 
Coercion. To maintain what it considers the integrity and standing of the profession, the American Medical Association has established a code of ethics to govern the behavior of practitioners. ${ }^{69}$ The most basic of its standards have usually been enacted into state medical practice laws. For example the felon, abortionist, alcoholic, ${ }^{70}$ and in some states the fee-splitter ${ }^{71}$ is subject to suspension or revocation of licensure. But the medical societies have more exacting standards governing virtually every aspect of medical practice and care. Because almost all physicians recognize the need for some such standards, application of sanctions is rarely necessary. ${ }^{72}$ However, this nearly unanimous agreement does not extend to some "ethical" interpretations which inhibit experimentation in solving problems of medical economics.

Because the AMIA has the consent and support of a great majority of doctors, its standards can often be enforced against an offender without formal action. The physician who is suspected of "unethical" practice may be subjected to professional ostracism. ${ }^{73}$ This may involve denial by member physicians of patient referrals and consultations, ${ }^{74}$ and the loss of advancement in hospital and other professional appointments. ${ }^{75}$ The mere availability of such sanctions is usually enough to deter possible violators of AMA's code of conduct.

If a physician does not respond to such techniques, formal sanctions may also be invoked. County medical societies generally have boards of censors to hear charges against members. ${ }^{78}$ A system of appeals is provided, culminating in the Judicial Council of the AMI. ${ }^{77}$ However, this body is bound

69. AMIA, Princtples of Medical Exhics (1952), discussed infra page 970 af se?. Many state societies have adopted the Principles as their own codes of conduct. E.g., Tex. MIEd. Ass's By-Laws c. 10, \$21 (1952); Va. Men. Soc By-Laws Art. 11 (1952).

70. E.g., 9 Iowa Code ANn. $\$ \$ 147.55-6$ (1946); Cone of VA. $\$ \$ 44-316-317$ (1) (2) (3) (1950).

71. E.g., 9 Iowa Cone ANn. $\$ 147.56(4)$ (1946); Cone of VA. $\$ \S 54278,54316$, 54-317 (6) (1950) (fee splitting a misdemeanor as well as grounds for license revoution).

72. Eleven societies report no expulsions during the last five years and in only one society were there more than five during this same period. Qezstrowsunne No. 41.

73. "First, of course, and never out of use [as a sanction], is social pressure in a small group. The social life of the county society is important to some doctors . . . a doctor can ill afford the hostility of an organized group in positions of local prominenee. ... Ostracism becomes a terrible weapon in such a business." Gaseziv 103. A state court has found the threat and practice of professional and sceial ostracism to a "hardship" to doctors, but did not find social ostracism to be an "official" technique of the society. Group Health Cooperative of Puget Sound v. King County Medieal Society, 39 Wash.2d 586, 627-9, 237 P.2d 737, 759-60 (1951).

74. GarceaU 103; Group Health Cooperative of Puget Sound v. King County Medical Society, supra note 73, at 663-4, 237 P.2d at 778.

75. Id. at 623-5, 664, 667, 669, $237 \mathrm{P} .2 \mathrm{~d}$ at 757-8, 778, 780, 781.

76. E.g., Tex. MEd. Ass'x By-Laws, c. 10, $\$ \$ 14,17,21$ (1952) (each county society to form a three-man board of censors to receive, investigate, and report on charges made by the public or fellow-members).

77. The Council's five members are elected for five-year terms by the AMA House of Delegates. It operates as the appellate "Supreme Court" of the Association and, where 
by findings of fact made at the local level. ${ }^{78}$ Those found guilty of violating the standards of the organization may be subjected to reprimand, suspension, or expulsion. ${ }^{79}$ Such safeguards as the requirement that charges be specified and proved and the right of appeal limit the availability of these sanctions.

The consequences of a denial of an application for membership are just as serious as those of expulsion. But admission is entirely at the discretion of the county society ${ }^{80}$ there is no right to a hearing and no appeal from the society's verdict. ${ }^{81}$ In one extreme case a county medical society dissolved itself and then reformed without an alleged offender, who was then

the AMA is a party, it has original jurisdiction over controversies arising under the Constitution, By-Laws, or Principles of Medical Ethics. The Council settles disputes between component societies or between members of different societies. It may also request the appointment of "investigating juries" to consider complaints of unethical conduct; if the jury's findings indicate "probable cause for action" the Association's President appoints a prosecutor to present the AMA's case against the accused; after hearing both sides the Council delivers a verdict and sentence. AMA By-LAws c. 10, $\$ 4(\mathrm{HI})(1)$ (1952) ; AMA, Guide to Services $52-3$ (1952).

78. "The Council shall have appellate jurisdiction in questions of law and proccdurc but not of fact in all cases which arise between . . . a member or members and the component society to which said member or members belong." AMA BY-Laws c. 10, § $4(\mathrm{H})(1)(1952)$.

The Judicial Council has recently adopted elaborate rules of procedure which provide, inter alia, that before the Council may assume jurisdiction, the aggrieved member must submit evidence that he has exhausted all county and state society remedies. 147 JAMA 1687 (1951).

On occasion the Judicial Council has reversed the decisions of lower medico-judicial bodies, indicating the Association's reluctance "to back the excesses of some component groups and [its insistence] on a properly conducted trial." GARCEAU 107. See 106 JAMA 300 (1936).

79. In some societies, members themselves vote upon the guilt of accused members, after hearing the report of the Board of Censors. Questronnaire No. 40. In Texas, if a majority votes "guilty" there is another vote taken to censor, suspend, or expel the accused. The first two sanctions require a majority vote while expulsion requires a twothirds. Tex. MEd. Ass'N By-Laws c. 10, § 21 (1952). However, in other societies expulsion is ordered by the Board of Censors alone. Questionnaire No. 40.

The AMA Judicial Council has similar powers to "acquit, admonish, suspend or expel the accused." AMA By-LAws c. 10, § 4(H) (1) (1952).

80. State constitutions often provide: "Each component society shall judge the qualifications of its own members, but as these societies are the only portals of entrance to this Society and to the American Medical Association every reputable and cthical physician having a degree of Doctor of Medicine from an accredited medical school and licensed by the [state] shall be privileged to apply for membership." KANS. MED. Soc. By-Laws c. $12, \S 5$ (1952); see also W. Va. State Med. Ass'N By-Laws c. 9, $\S 5$ (1952).

The New York State society expressly prohibits denial of membership because of race, color, or creed. You and the Medical Society of the State of New Youk 14 (1952).

81. Hearings before Committee on Education and Labor on S. 1606, 79th Cong, 2d Sess. 2637 (1946). The AMA also declines jurisdiction over denials of membership in county societies. Id. at 2638 . 
denied admission and had no further recourse. ${ }^{22}$ The threat of denial is particularly effective in controlling the behavior of the young physician who desires membership, as well as of the doctor who has transferred his residence. ${ }^{83}$

The importance and effectiveness of these formal sanctions is reflected by their severe consequences. In addition to the imposition of the informal sanctions mentioned above, the physician who is expelled or denied membership loses the positive benefits and economic advantages conferred by organized medicine. Membership in organized medicine has also been adopted by some outside groups as a criterion of professional competency. 84 Non-membership may raise questions regarding the character of an applicant for reciprocal licensing privileges. ${ }^{85}$ The non-member will also find it difficult to obtain malpractice insurance on terms comparable to those offered members, if he can obtain it at all. In one instance doctors were forced to obtain insurance from Lloyds of London after being refused by American companies. ${ }^{86}$

The most serious consequences of rejection or denial are those which handicap the physician in the actual practice of his profession. ${ }^{87}$ As a non-member,

82. SHadid, A Doctor for the Peorle 133 (1946).

83. Many societies treat physicians who have moved into their areas as new applieants despite a former status as member in good standing in another society. Quesnowmane No. 33. Or societies may require or request transferees to submit evidence of good standing in their former county societies. Id., Nos. 33-4.

Transfer of membership to the Washington State Society was refused physicians who intended to practice with a disapproved group. Group Health Ccoperative of Puget Sound v. King County Medical Society, 39 Wash.2d 586, 626-7, 237 P.2d 737, 759 (1951). See also Stand, A Doctor for the People 136-8 (1939).

S4. During World War II an application to serve as a medical officer in the U.S. Navy was not considered "unless accompanied by a letter certifying that the asplieant was a member in good standing in [a] society." Hcarings, sistra note 81, at 2642. But this requirement is not currently imposed. Letter to the YaLe LAW Jounial from Captain W. B. Mosser, U.S.N.R, dated Feb. 26, 1954, on file in Yale Law Library.

85. Some states have the following requirement: an applicant seding a license under reciprocity provisions must present a certificate signed by the president or secretary of his former county or state society, stating that he is an ethical practitioner and of good moral character, or a recommendation from two reputable physicians who are members of the so-

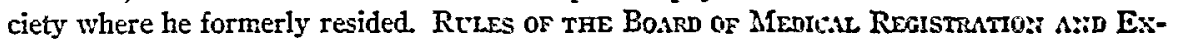
amination of the State of Kansas 23 (1943). See also Shamb, A Dotour fur tae PEOFLE 137-S, 207 (1939).

86. Hearings, supra note 81 , at 2643 ; Smann, op. cit. supra note 85 , at 134 . Although only a few state societies presently write a griup malpractice liability policy for their members, such policies are frequently written at the county level. And many sucieties aid their members in obtaining malpractice insurance elsewhere. The rates of commercial insurance companies are sometimes from $20 \%$ to $100 \%$ higher for non-society members and some insurance companies refuse to issue any policies to non-members. Questionainme Nos. 55-7.

87. In general a physician's ability to continue his professional development is restricted by the loss of participation in scientific programs and professional relationships. And a rejected doctor is denied the use of the medical societies as a forum for bringing his own discoveries before the profession. The non-society member is "quite generally regarded as an outcast." Group Health Cooperative of Puget Sound v. King County Medical Society, 39 Wash.2d 586, 626, 237 P.2d 737, 759 (1951). 
he is ineligible for specialty board examinations and ratings. ${ }^{88}$ Referrals and consultations, so essential to the growth of a new practice, are denied him. ${ }^{80}$ Expulsion or denial carries the stigma of unethical practice so that members who have professional relations with a rejected practitioner may themselves be considered unethical. ${ }^{00}$ Thus, as part of its enforcement program one medical society circulated a "white list" of approved doctors to its members."1 The disapproved physician will also be handicapped in caring for his patients. Unless he relinquishes control over the patient he may be unable to secure assistance in time of emergency. ${ }^{92}$ Perhaps most important, he will be denied the use of most hospital facilities. The Mundt Resolution, passed by the AMA House of Delegates in 1934, advises that the staffis of hospitals accredited for internship training be composed solely of members of local medical societies. ${ }^{93}$ Accordingly, hospitals with a combined total of up to $99 \%$ of

88. E.g., the American Board of Internal Medicine requires applicants for examination to be "active members in good standing" of the county and state societies in their states of residence; the American Board of Orthopaedic Surgery requires applicants for the Part II Examination to have membership in the AMA or Canadian Medical Association; both the American Boards of Ophthalmology and Psychiatry \& Neurology recuire all candidates to be members of the AMA or of such other societies as are recognized for the purposes of certification by the AMA Council of Medical Education and Hospitals. 150 JAMA 384, 394, 396, 411 (1952). See Group Health Cooperative of Puget Sound v. King County Medical Society, 39 Wash.2d 586, 626, 631-2, 237 P.2d 737, 759, 761-2 (1951).

89. Group Health Cooperative of Puget Sound v. King County Medical Society, supra note 88 , at $626,663-4,237$ P.2d at 759, 778 (denial of right of consultation considered "effective and damaging" weapon). See Garcenu 103.

However, all societies responding to the Questionnaire state that they do not disapprove of consultations or referrals between members and non-members, although the question made no effort to single out the treatment accorded a disapproved physician. QuestionNAIRE No. 44.

90. E.g., Group Health Cooperative of Puget Sound v. King County Medical Society, supra note 88, at 601, 237 P.2d at 746 (county society resolution condemning "association" by members with non-member group practitioners).

91. United States v. American Medical Association, 110 F.2d 703, 706-7, 715 (D.C. Cir.), cert. denied, 310 U.S. 644 (1940) (list circulated "for the purpose of threatening with disciplinary action any member ... who ... consulted with [disapproved] doctors. ...").

92. Group Health Cooperative of Puget Sound v. King County Medical Socicty, 39 Wash.2d 586, 619-20, 624, 237 P.2d 737, 755-6, 758 (1951) (Group Health physicians denied "courtesy privileges" at city hospitals). One hospital refused a Group Health physician access to its facilities in an emergency, forcing a seriously ill patient to be taken through a.snow storm to a distant hospital for treatment by the physician of his choice. Id. at 624,237 P.2d at 758.

93. Fishbein 403-4. For one instance of the use of this resolution, sec Americat Medical Association v. United States, 130 F.2d 233, 250 n.87 (D.C. Cir. 1942), aff'd, 317 U.S. 519 (1943) : The Secretary of the Wisconsin society cited the Mundt Resolution in a letter to a Milwaukee hospital superintendent who retained on his staff physicians expelled for participating in a prepaid group practice. When the superintendent failed to drop these physicians from his staff, he was notified by the state society that it was recommending removal of the hospital from the "approved intern list" and the AMA Register. 
their state's bed capacity require membership. ${ }^{04}$ Others give non-members limited privileges, or extend staff membership only to society members and those "qualified" for membership. ${ }^{95}$

The medical societies will rarely choose to disrupt the professional life of non-members eligible for membership, or those excluded only by racial barriers. Member physicians will often cooperate with such doctors; they may find less difficulty in obtaining hospital appointments and may be invited to participate in the scientific programs of the medical society. ${ }^{00}$ It is the practitioner who is expelled or denied membership who finds the punitive tactics of organized medicine employed to their fullest against him. In these cases non-membership amounts to a partial revocation of licensure to practice medicine. ${ }^{07}$ It is only the established physician with guaranteed tenure on hospital staffs and specialty boards, or one who has the security of a faculty or governmental position who can afford to challenge the ethical standards of the AMA. Few doctors enjoy such a status, and defiance of AMIA authority means professional suicide for the majority.

\section{The financial basis of pourer}

Physicians receive an average income higher than that of any other professional group. ${ }^{98}$ Consequently, organized medicine can receive considerable financial support by drawing on the resources of its membership. On the county level, where dues are the major source of revenue, assessments vary from nominal amounts to as much as $\$ 125$ per year. ${ }^{.3}$ State dues range from $\$ 20$ to $\$ 55$ annually, ${ }^{100}$ while the AMA itself assesses each of its members $\$ 25.101$ On the state and national levels considerable income is also derived from subscriptions and the sale of advertising in the societies' publications. ${ }^{102}$

"One week later the Superintendent . . . wrote ... that the objectionable physicians had been denied further staff courtesy privileges of the ... Hospital by vote of the Executive Committee."

94. Over half of the societies reported membership as a prerequisite for appointment to at least some of the hospitals in their states. In five states the medical societics reported that this membership requirement covered "practically all" the hospital hed caracity in the state, while $40 \%$ was the lowest bed capacity tigure cited. Forty percent of the hospitals in one state have this requirement, and $90 \%$ or more in five states. Questu:aine $\mathrm{No}$. 54.

95. Hearings, supra note 81 , at 2642 .

96. See sipra note 22 .

97. Hearings, stipra note 81 , at 2642 .

98. Weinfeld, Incone of Paysicians, 1929-49 p. 10 (U.S. Dep't of Commerce, 1951).

99. Questionnaike No. 13.

100. QUestionnarre No. 12. Dues paying nembers sometimes receive the society journal free or at reduced rate $I d .$, No. 25.

101. AMA, Gutde to Services 17 (1952). A subscription to the Jourital is included in the dues.

102. In 1951 the AMA derived $19 \%(\$ 1,712,000)$ of its income from subseriptions and $30 \%(\$ 2,696,000)$ from advertisments in its publications. AMA, Gumz ro SEnvicss 10 (1952). 
Total revenues of the national organization exceed $\$ 9,000,000$ per year. ${ }^{103}$ State societies have incomes ranging as high as $\$ 500,000.104$ With only 1601 dues-paying members the Colorado State Medical Society, for example, has an annual income of $\$ 120,000.1^{105}$ Similarly, the financial strength of many of the county societies assumes considerable proportions. This stubstantial economic support enables organized medicine to attract new members, and to engage in a variety of costly activities which serve to enlarge its power and influence.

\section{The political basis of power}

Prestige. The political strength of the AMA is to a large degree attributable to the status of the doctor in society. Because of his services to humanity, his learning, and economic position, the physician enjoys prestige and public confidence. The public looks to the doctor for advice and gives great weight to his opinion. ${ }^{106}$ This trust, unchallenged in the realm of medical science, extends also into economic and political aspects of health. Because of the AMA's high percentage of physician membership and its status as spokesman for the doctor, the lawmaker turns to organized medicine to ascertain medical opinion.

Mastery of political tactics. Attempting to influence governmental decision is one of the historic purposes of organized medicine. ${ }^{107}$ Without encouraging public action of a regulatory nature, the early medical societies could not have fully realized their objective of raising medical standards. But regulation of the professions is a function of the states, and medical legislation has been, until recently, devoted primarily to policing medical practice rather than providing medical care. ${ }^{108}$ So the American Medical Association had few

The California Medical Society obtained $\$ 143,250$ of its $1951-2 \$ 566,250$ income from subscriptions, reprints, and advertising attributable to its journal. In its 1952-3 budget the society hopes to increase its advertising sale by $\$ 20,000$. California Questionnaire (Budget). And Colorado's 1952-3 budget lists $\$ 35,100$ of its $\$ 120,000$ revenues as derived from subscriptions to its journal. Colorado QuestronnaIRE (Budget).

103. AMA, Guide to Services 10 (1952).

104. California Questionnaire (Budget).

105. Colorado Questronnaire (Budget).

106. "Doctors properly rate high in the social scale and sometimes politically they exercise important influence. The reasons are partly the many varied contacts they have with cases and people and partly the professionally-trained type of personnel they have become. Thereby they qualify to teach of things that relate to the body and that people do not any too well understand and likewise exert over them an infuence in political and family matters." Brown, Organization for Health 15 (1938).

107. One of the principal reasons for the organization of the Medical Society of Virginia was "to memorialize the legislature of Virginia for the passage of a Medical Practice Act." Branton, Medictne in Virginia 110 (1923). Reporting in 1854 upon the early accomplishments of AMA, the President cited as highly important the AMA's role in "the enactment of wholesome laws both by the Federal and State Governments." Fishbein 59.

108. Garceau 14. 
occasions to influence political action on the national level. ${ }^{109}$ However, with growing public acknowledgment of governmental responsibilities in furnishing medical care ${ }^{110}$ the political activities of the AMIA have expanded enormously. ${ }^{111}$ This development, most pronounced on the federal level, has also been manifest in the states. ${ }^{112}$ But while the public may have confidence in the judgment of individual doctors, it may be suspicious of selfish motivations in an organized group. Therefore organized medicine's new "lobbying" has developed techniques of creating a favorable public opinion to supplement the older techniques of direct contact with lawmakers. ${ }^{113}$

The American Medical Association is considered by some observers the most powerful legislative lobby in Washington.114 Measures apparently assured of passage have been voted down, buried in committee, or substantially amended upon the announcement of AMIA disapproval.115 In physical size the AMA's lobbying facilities are not impressive. 110 Yet during 1949 and 1950 the AML reported the highest expenditures of any group registered

109. In 1899 the Committee on National Legislation was first created to represent the AIIA. Fis HBEan 1018. As recently as 25 years ago the AMIA's lobby was deccritiod as relatively inactive. Herreng, Group Representatron befune Congress 184 (1929).

110. Anderson, Pablic Health-A Mandate from the Pcople, 42 Ass. J. of Puntic HeALTH 1367, 1369 (1952).

111. The Doctor in Politics, Consumer Reports, Feb., 1950, p. 75; Means, The Doctors' Labby, Atlantic Monthly, Oct., 1950, p. 57. See pages 997-1006 infra.

112. See text at note 133 et seq., infra.

113. See text at notes 645-S, 659-62 infra.

114. "Some rather expert observers of the art of lobbying as practiced in Washington assert that the AMA is the only organization in the country that could marshal 110 votes in Congress between sundown Friday night and noon on MIonday. Performances of this sort have led some to describe the AMIA lobby as the most powerful in the country:" Huston, $A M A$ is Potent Force Among the Lawnalers, N.Y. Times, June 15, 1952, \$ 4, p. 7 , col. 6 .

115. E.g., in 1950 the AMIA Washington office reported that no bill opposed by tite AMIA had been passed by Congress and that several favored by the AMA were enacted. 144 JAMIA 637 (1950).

The 1952 social security bill was defeated by a 150 to 140 vote after the AllA had announced its opposition to a single feature of the bill. A few days prior to the A.MA's anouncement, proponents had been able to muster a two-thirds vote for a suspension of the rules, apparently ensuring an immediate favorable vote. Huston, sis ro note 114.

See also 143 JAMIA 1264 (1950) (federal aid to medical education bill pigeon-holed); 143 JAMA 478 (1950) (provision in 1950 social security bill dropped). See generally pages 1000-6 infra.

116. The Washington office, established in 1944, has only three registered lobbyists, although a few state societies also send representatives to Washingtun.

Mieasures proposed in Congress are studied and reports on bills of medizal interest are made to a committee of the Board of Trustees and a decision is reached on what position, if any, the Association will take. 144 JAAIA 637 (1980); Ir's YoLB AMIA 21 (1953). Once the organization's position has been determined, legislators are infurmed of it and public pressure is brought to bear on important measures.

Personal contact with legislators is stressed and the fiersonal physician of every Congressman is informed of the stand taken so that he may present the Assoviativis views if the occasion arises. The Doctor is Politics, Consumer Repurts, Feb., 19:0, 
under the federal lobbying law.117 While its financial outlay has since declined, ${ }^{118}$ its potential influence remains unimpaired.

Both national and state organizations have public relations programs to present the views of organized medicine. ${ }^{110}$ Attempts are made to solicit editorial support ${ }^{120}$ and societies have purchased advertising in the press and on radio and television. ${ }^{121}$ These efforts are generally designed to illustrate the achievements of American medicine; sometimes they may be directed to medico-political issues. ${ }^{122}$ Member physicians are urged to participate in these political endeavors by delivering public addresses-the texts of which are often furnished by state or national headquarters, ${ }^{123}$ and by distributing literature in waiting rooms ${ }^{124}$ and with monthly bills. ${ }^{125}$ Doctors' wives, working through medical society auxiliaries, are also active in this type of work. ${ }^{120}$

Organized medicine also attempts to demonstrate numerical support for its position by getting outside groups to "go on record" as allies. ${ }^{127}$ Related pro-

pp. 75, 76. At Committee hearings it is customary to have high officials of the AMA and state societies appear to testify.

Those opposing the AMA's stand are frequently labelled "subversive" or accused of selfish motivations. See e.g.: "Nickolay Lenin, one of the Gods of the Marxist party line, laid down this fundamental precept: 'socialized medicine is the keystone to the arch of the Socialist State.' " AMA, Comprrsory Health Insurance-Politically ConTRorled Medicrne 17 (1949). See also Means, The Doctors' Lobby, Atlantic Monthly, Oct., 1950, pp. 57, 58.

117. 7 Cong. QUARTERLy Almanac 718 (1951) (the AMA's 1950 lobbying allocation was $\$ 1,326,078$.)

118. In 1952 the AMA was reported as the second highest spender among registered lobbyists in Washington. The Association reported expenditures of $\$ 309,514$ for that year. N.Y. Times, May 3, 1953, p. 34, col. 1. In 1953 it dropped to sixth place, reporting expenditures of $\$ 106,624$. New Haven Register, Apr. 6, 1954, p. 14, col. 2.

119. AMA, Guide to Services 68 (1952). Many state societies employ full- or part-time public relations officers. QUESTIONNAIRE No. 62.

120. See text at notes 620,635 infra.

121. Several societies purchased, or were given as a "public service," newspaper space and radio or television time for public information and "AMA campaign" purposes. QuestTonnaire No. 64.

122. See collection of newspaper advertising layouts on file in Yale Law Library.

123. See note 659 infra.

Thirteen state societies reported the existence of state or county Speakers Burcaus and one society was supplied with speakers by the AMA Councils on Medical Service and Public Relations. Questionnaine No. 63. The AMA Department of Public Relations will furnish state and county societies with slides and "sample talks" describing AMA activities. IT's Your AMA 26 (1953).

124. Almost all societies reported that members displayed pamphlets in their waiting rooms during the AMA's campaign against compulsory health insurance. QuestronNAikE No. 80. Initial shipments from national headquarters to state societies were to be "on the basis of 50 pamphlets per doctor." A Simplified Blueprint of the Campaicn against Compulsory Health Insurance (1949) (hereinafter cited as Blueprint).

125. Doctors' bills "are covered with stickers reading, 'as your personal physician . . . Please write your U.S. Senators and Representatives. For more information, ask me.' " Mayer, The Dogged Retreat of the Doctors, Harper's, Dec. 1949, p. 25.

126. AMA, Puitring PR to Work 64 (1st Public Relations Institute, 1952).

127. See text at notes 645-6 infra. 
fessions in particular share common political interests with medicine. The recently formed Inter-Association Committee on Health, consisting of the AMA and the American Dental, Hospital, Public Health, Nursing, and Public Welfare Associations, serves as liaison in this area. ${ }^{128}$ During health insurance controversies, medical supply houses, pharmaceutical firms, and insurance companies cooperated closely with the AMIA, rendering financial assistance and publishing tie-in advertising furnished by the medical societies.200

Some of organized medicine's present political power may be attributable to the increased activity of its members in political affairs. The AMA supports no party or candidate, but in many localities physicians organize separate "healing arts" committees to campaign for candidates favorable to the Association's views. ${ }^{130}$ The formation of these committees has been approved and their choice of candidates endorsed in some instances by local medical societies, ${ }^{131}$ although the latter practice is not common. The work of these healing arts committees is thought to have been influential in several close congressional contests and primaries. ${ }^{132}$

The medical societies also exert great influence over medical legislation on the state and local levels. The enactment of favored measures and the defeat of those opposed can usually be secured. ${ }^{133}$ State societies have a lobbyist or legislative agent, often the executive secretary.134 The societies also actively encourage their members to run for legislative positions to insure adequate representation of the organization's interests. ${ }^{135}$ Personal contact with each legislator, if possible by his own physician, is stressed. ${ }^{138}$ County societies

128. See 146 JAMIA $\$ 35$ (1951).

129. Questionnaire No. $\$ 1$; The Doctor in Politics, Consumer Reports, Feb., 1950, pp. $75,76-7$.

130. QUestionNaIRE No. 80 .

131. E.g., in Pennsylvania's 26th Congressional District the Healing Arts Committee's candidate was officially endorsed by the Cambria County Medical Society. The Society was also active in the Committee's formation. Cunningham, Coss Palifical ilcans Gain Professional Ends?, Modern Hospitals, Dcc, 1951, p. 51.

132. In Florida the defeat of Senator Pepper by Congressman Smathers "can be attributed in part to their respective stands" on health insurance. Flondo. QUestro:s:alne No. 83.

The New Hampshire Society takes credit for making greater the already inevitable defeat of a pro-health insurance candidate. NEw Hasipsmine Questro:usame No. 83.

In Montana a Senatorial incumbent favoring health insurance was re-elected, but the society claims his victory cannot be attributed to his stand on that issue. Mo:sta:a Questronnaire No. 83.

133. Almost all societies report that their members have been active in drafting subsequently enacted legislation such as state Basic Science Laws and MIcdical Practice Acts. QuestionnaIRE No. 67.

134. QUestionNaire Nos. 65-6.

135. See, e.g., Iowa State Mifdrcal Soctety, Hanoroor for tue House or DeleGATES 49 (1952). And it is not uncommon to find society offeers serving in the legislatures. See note 139 infra.

136. The Doctor in Politics, Consumer Reports, Feb., 1950, pp. 75, 76; 31 N.Y. Srate J. OF MED. 109 (1931). 
may also endeavor to have prominent local doctors write their legislators and encourage their patients to do likewise. ${ }^{137}$ Much state medical legislation originates with the state societies $;{ }^{138}$ bills are often drafted with the aid of counsel, and such measures are easily introduced. ${ }^{130}$

While influencing the actions of legislative bodies constitutes the most apparent means of determining governmental action, the continuing relationships of organized medicine with administrative agencies are no less important. It is at this level that much public health legislation originates ${ }^{140}$ and is implemented by rules and regulations; here also enforcement takes place. The AMA and its constituent societies have many councils and committees which serve public agencies in an advisory capacity. ${ }^{141}$ Such bodies can gather information of a professional nature not readily available to government officials. And by receiving the views of the profession on specific regulations the public agency obtains the opinion of one of the groups vitally affected and whose cooperation is necessary for the success of most programs.

The medical societies have also attempted to increase the profession's influence in administrative decisions by trying to make medical licensure a prerequisite for positions of control over health or medical programs. ${ }^{142}$ The

137. The New York Society's legislative agent suggests the names of legislators to whom prominent local physicians should write and all county members are urged to contact their patients. New York Medical Society Legislative Bull., March 3, 1953.

138. QUESTIONNATRE No. 67.

139. E.g., in 1935 Dr. Marcus Newcomb was majority leader of the New Jersey Assembly and in 1936 served as Speaker. During this period he was also President of the New Jersey State Medical Society and managed all public health bills in its behalf. McKean, Pressures on tee Legislature of New Jersey 232 (1938).

140. Anderson, Public Health-A Mandate from the People, 42 AM. J. of Punuc HEALTH 1367 (1952).

141. E.g., the AMA Council on Food and Nutrition works with federal and local health regulatory agencies; the Committee on Federal Medical Services cooperates with Governmental groups; and in 1949 the Director of the Bureau of Health Education was loaned by the AMA to military government as a consultant in public health practices. AMA, Guide to Services 39, 58, 65 (1952). And in New York the state society's Workmen's Compensation Bureau has worked closely with the state's own Workmen's Compensation Board on matters involving medical practice under state law. You AND TuE Medical Society of the STATE of NEw YoRK 35-7 (1952). One of the reasons for placing organized medicine in a position of responsibility was the eradication, in industrial accident cases, of fee splitting and "kick-backs" at the state's expense. Governor Herbert Lehman's Special Message to the Legislature (1.934), quoted in Greenberg, Studics of Medical Leadership: The New York County Medical Society and Workmen's Compensation, Physicians Forum Bull., Sept., 1951, p. 11. But the societies' representatives have been severely criticized for having "seemingly closed their eyes to this widespread system, except as to one commercial establishment engaging in $\mathrm{x}$-ray examinations in competition with physicians. ..." Report to Governor 'Thomas E. Dewey by Commissioners to Examine and Investigate the Administration of the Workmen's Compensation Law of the State of New York (1944), quoted in Greenberg, supra, at 12.

142. "Public health relies in the last analysis on medical science. . . The physician must be a central figure in any successful public health program." Bauer, The Physician's Place in the Health Program, 107 JAMA 485 (1936). See also 143 JAMA 560 (1950); text at note 495 infra. 
influence of medicine upon administrative agencies is probably stronger on the state than on the national level. Many state health officials are appointed on the recommendation of the medical society, ${ }^{1.33}$ and it is often through their offices that federal health grants are administered. Health officials, lnowing the legislative influence of the medical societies, are not likely to incur their antagonism. Having accused Federal Security Administrator Osear Ewing of sympathies toward "socialized medicine," the AMIA consistently opposed provisions which would grant his agency discretionary authority in administering health programs. ${ }^{144}$ But such outright enmity between organized medicine and health agencies is the exception rather than the rule.

Legal recognition. As a consequence of its monopoly position, financial resources, and political strength, organized medicine is able to maintain a quasi-legal status in medical affairs. In many states, laws authorize state and local medical societies to appoint or recommend members of regulatory bodies. ${ }^{145}$ AMA standards in medical education, training, and practice are usually adopted by law. In addition, AIIA inspection to determine whether its own standards have been satisfied is seldom subject to judicial review. Thus the political authority of the state itself has in effect been delegated to organized medicine.

\section{The Application of Aila Power}

No aspect of medical affairs-from Hadacol ${ }^{146}$ to health insurance ${ }^{147}$-is outside the scope of AMA interest. The power of organized medicine is exerted in a wide variety of ways. Its activities may conveniently be categorized as raising the quality of medical services, determining the conditions of practice and payment, and controlling an ever-expanding governmental interest in the national health.

\section{Scientific activities}

\section{Promoting the Quality of Medical Scrvices}

Historically, the AMA has exerted influence and directed more than half its yearly expenditures into "scientific activities."118 It has felt a vital interest

143. Questronname Nos. 36,38 . In over half the states reporting, the societies recommend appointees for heads of the state health departments, while in Alabuma the society itself makes the appointment.

144. See, e.g., text at note 500 infra.

145. In half the states reporting the society recommends appointees for the State Board of Medical Examiners, in others the society nominates candidates for this office, and in one state the State Mledical Society Board of Censors itself constitutes the State Board of Medical Examiners. Questionnime No. 31. See, e.g., Coms. Gen. Stats. $\$ 4365$ (1949) (nominations by society); MLAss. Laws Aws. c. 13, $\$ 10$ (1952) (Governor appoints with consent of society).

146. See 145 JAMA 107 (1951). See also, e.g., 143 JAMIA 555 (1950) (report of AMA inspection of a health resort).

147. See pages $980-96,1007-17$ infra.

148. See, e.g., AMIA, Gume to SERvices 11 (1952) (1951 balance sheet, showing 549. of AMA expenditures for "scientific activities"). 
in the quality of products closely related to the practice of medicine. In the early years, the AMA's efforts in this respect were designed primarily to eliminate extravagantly advertised nostrums. ${ }^{140}$ Since then it has adopted a more positive approach - the policing and promotion of higher standards for recognized medical products.

Through laboratory tests and expert evaluation, AMA Councils examine new drugs and medicines, dietary and other special-purpose foods, and therapeutic and diagnostic devices. ${ }^{150}$ A manufacturer of any such product may obtain an evalution at no charge, or the AMA may investigate on its own initiative. ${ }^{151}$ Standards are above the bare minimum of harmlessness ; requirements as to purity, effectiveness, and the truthfulness of the manufacturer's claims must be met. ${ }^{152}$ Even AMA critics concede the impartial scientific basis upon which the judgment is rendered. ${ }^{153}$ Products which meet AMA standards receive the privilege of displaying the Seal of Acceptance in their medical journal or lay publication advertisements. ${ }^{154}$ But the Seal of Acceptance is of greater value to a manufacturer than a mere advertising device. A medical product must be "accepted" before its manufacturer can buy advertising space in the Journal or in the great majority of state society journals. ${ }^{165}$ Thus, products which depend to a great extent upon a doctor's prescription or recommendation cannot advertise in the medium which best reaches the medical profession unless AMA standards are met.

To buttress its work in this field, organized medicine has campaigned for legislation to protect the consumer further. The AMA was a sponsor of the Pure Food and Drug Act of $1906^{156}$ and it has promoted similar state measures. ${ }^{157}$ Moreover, a provision in the AMA code of ethics forbids memberdoctors from prescribing "unknown or secret remedies." 168 Infractions are

149. FishBeIN 233, 235, passin.

150. AMA, Guide to Services 36-41 (1952).

151. Id. at $37,39,41$.

152. Id. at 39. See also 135 JAMA 159 (1947) (withdrawal of acceptance for alleged extravagant advertising). Cf. N.Y. Times, Nov. 11, 1953, p. 41, cols. 2-3.

153. See, e.g., Mayer, The Rise and Fall of Dr. Fishbein, Harper's, Nov., 1949, pp. 77-8. (" $[T]$ here has never been even the flimsiest support of the charge that the Seal of Acceptance could be had under the counter. ..."); Rorty, Whose Mcdicinc?, The Nation, July 11, 1936, p. 43 (placing of advertising in the Journal not a condition of Acceptance "[b] ut a dubious and uncomfortable 'community of interest' has been established [between organized medicine and the manufacturers of proprietary medicines]."). See also The American Medical Association, Fortune, Nov., 1938, p. 89 (as of 1938, suits against the AMA for unfavorable notices of products totalled $\$ 35$ million; total damages assessed, one cent) ; Fishbein 495-533.

154. AMA, Guide to Services 37, 39 (1952).

155. Id. at 36; Editorial: Scientific Medical Advertising, 136 JAMA 400 (1948).

156. Fismibein 234-43 (1947). See also id. at 1030-1.

157. See, e.g., AMA, Proposal for a Uniform State Law Governing Distribution of Lyc and Other Caustic Substances (1928 draft) (copy on file in Yale Law Library).

158. AMA, Principles of Medical Ethics c. $1, \S 6$. 
rare, for few physicians would rish use of a medicine untested by the Association's staff. 159

The AMIA does not attempt to develop new medical products directly, but it does foster independent research. ${ }^{100}$ The Committee on Research awards grants to projects which have particular medical significance. ${ }^{101}$ The Committee also obtains outside sponsorship, often from pharmaceutical firms, for clinical studies of disease, nutrition, and long-term effects of new medicines. ${ }^{162}$

\section{Post-graduate medical education}

The practicing physician must keep himself informed of improvements constantly being made in the field of medicine. And the average doctor has come to depend on his society as a highly important source of new medical knowledge. ${ }^{163}$ The process of instruction on the local level is carried on at society meetings largely by speakers from medical school faculties or the staffs of large hospitals. This service is of particular importance to "country doctors" whose contact with medical progress might otherwise be limited. The societies provide specialized courses of instruction, ${ }^{10 s}$ and, at their annual meetings, arrange for a concentrated series of scientific papers, demonstrations, and exhibits. ${ }^{16 j}$ Moreover, most state societies, or a small group of state societies, publish a journal, ${ }^{160}$ largely devoted to scientific matters. The national organization's most effective means of keeping physicians informed is through its publications. The Journal, published weekly, has the largest circulation and

159. The case of Dr. Andrew C. Ivy, who was suspended from the Chicago Medieal Society, is an exception. Dr. Ivy, a notable physiologist and head of the University of Illinois medical, dental, and pharmacy schools, was disciplined by the local society for having prescribed the then "secret drug" krebiozen in his search for a cancer cure. K.Y. Times, Nov. 14, 1951, p. 22, col. 5 .

160. Of great service to independent scientific research has been the effort of organized medicine to resist the passage of anti-vivisection legislation. Recently the state socicties have seized the initiative and, in a few states, procured the passage of compulsory pound acts. These bills give express authority for animal experimentation and enable a state official to requisition impounded animals for distribution to approved latoratories. See generally, Menges, Anti-Vizisectionists on the Run, Medical Economics, April, 19\$2, p. 74. See also News Letter, Massachusetts Medical Society, Dec. 14, 1950, p. 2 (urging the support of all physicians and their wives in procuring passage of such a measure). For an example of a Compulsory Pound Act, see N.Y. Peb. Healtru Law \$ 53 (MIcKinney, Supp. 1953). Several state medical societies report that no appreciable anti-vivisection opposition remains. QUEstTonnatre Nos. 58-9.

161. AMIA, Guide to Senvices 47 (1952).

162. Ibid.

163. AMA, Activities of County Medical Socreties 2 (1951).

164. See, e.g., 150 JAMIA 127 (1952), for a report on postgraduate and continuation courses offered under the auspices of organized medicine.

165. AMA, Guine to Services 26, 30-3 (1952).

166. Examples of jointly-sponsored journals are the Rochy Moumtain Mcdical Journal (Colorado, Utah and Wyoming), and Northriest IIcdicinc (Alasha, Idaho, Oregon, and Washington). 
is one of the most respected of the world's medical periodicals. ${ }^{107}$ Its staff selects about six hundred of the most outstanding of several thousand manuscripts submitted annually for publication. ${ }^{168}$ Its special departments, in addition to organizational and political news of interest to doctors, include reports of the tests conducted by various AMA councils and committees, medical book reviews, a medical question and answer column, and medico-legal information.

The AMA's Scientific Sections, representing the various medical specialties, each present full programs at the annual national conventions. ${ }^{100}$ Nine of these specialties also publish their own monthly journals geared to the specialist's needs. ${ }^{170}$ Also valuable to the physician are the AMA's quarterly index of medical literature, a directory of licensed physicians in the United States and Canada, and various handbooks on drugs and diseases.

\section{Services to the public}

Much of the AMA's contact with the public is in the field of health education. Today's Health, a monthly publication, is written for the lay reader; its purposes are to gain public backing for health measures supported by organized medicine, and to foster understanding of the developments in medical science. ${ }^{171}$ The Bureau of Health Education also maintains a speaker's bureau, offers an extensive radio transcription service, and has recently added a series of packaged television shows. ${ }^{172}$ Another type of AMA educational work is directed toward making the member physician a more effective health educator. Materials on public speaking, radio presentation, health column writing, and program planning are available to members. ${ }^{173}$

The AMA also engages in extensive activities within specialized areas of public health. Association officers have cooperated with the National Education Association and other interested groups in formulating school health policies and programs. ${ }^{174}$ The Chicago headquarters has full-time personnel

167. The Journal currently publishes 165,000 copies every week.

168. AMA, Guide to Services 74 (1.952).

169. Id. at 26-9.

170. Id. at 75 .

171. Id. at 77 .

172. AMA, Guide to Services 64-5 (1952). See also Hester, AMA Radio HandBOOK (1946); Hester, AMA TELEvision HANDBOOK (1951).

173. See, e.g., Bauer, Dramatizing the Health Message 30 AMA BuLn. 97 (1935); Bauer, Teach Health, Not Disease, 12 J. Healte \& Pyysical Ed. 296 (1941); Teschner, When Doctors Address the Public, 110 JAMA 155 B (1938); Writing A Health Columm, 109 JAMA $1926-7$ (1937).

174. See, e.g., Nat'i Comar. on School Healta Policies, Suggested School Healte Polictes (2d ed. 1950) ; Smiley \& Hein, Health Appraisal, of School CuilDREN (1948) (Nat'1 Ed. Ass'n and AMA joint report); Rice, Healte Conditions Affecting the Personality of School Youth (1952) (same); The Physical EduCator Asks About Health (Rugen, ed. 1951) (same). 
engaged in industrial health, ${ }^{175}$ rural health, ${ }^{170}$ and civil defense work. ${ }^{177}$ In all of these activities the AMA works closely with lay organizations to cosponsor conferences, stimulate interest, and publish materials.

\section{Setting the Qualitative and Quantitative Standards for MLdical Practitioners}

\section{The campaign against non-medical practitioners}

To protect the public against treatment by improperly trained practitioners, all states have passed statutes making a license prerequisite to the rendering of healing art services. ${ }^{178}$ Legislative pressure by state medical societies has been largely responsible for the original passage and periodic revision of these Niedical Practice Acts. ${ }^{170}$ Licensing requirements provide for minimum educational standards and successful completion of an examination given by a state examining board.

Quacks. One of the AMIA's first goals was to bar from practice a wide variety of completely unqualified healers. ${ }^{180}$ This campaign complemented its role in removing non-scientific remedies from the market. 181 Licensing requirements forced the quacks to withdraw or practice illegally. ${ }^{182}$ Since passage of these laws, the AMI's function in this field has been primarily one of policing. ${ }^{183}$ Advertising often provides a clue; the quack still relies upon ballyhoo to attract patients. ${ }^{184}$ Since the turn of the century, various medical societies have exposed mail order "diagnosis" by urinalysis, ${ }^{185}$ vacuum "treatments,"186 cancer "cures," diabetes "cures," virility "regenerators," and a wide variety of electric, radioactive, or otherwise miraculous remedies-all dispensed by unlicensed practitioners. ${ }^{187}$ The Association's Bureau of Investigation in Chicago keeps a file of known offenders and supports county and state societies in their detection and prosecution of the unlicensed invader, ${ }^{183}$

Chiropractors and Osteopaths. The emergence of conflicting theories of

175. AMA, Gume to Services 34-5 (1952). See generally, Herr, Sarety Actirites of the ANERICaN MEdical Association (mimeo. report, undated) (copy on file in Yale Law Library).

176. AMA, Guide to Services 62-3 (1952).

177. Id. at $60-1$.

178. See, e.g., 5 ARIz. Code Ann. c. 67, art. 11 (1939); 2 Rev. Laws N. Huzsp. tit. 21 (1942).

179. See, e.g., notes 107,133 supra.

180. FISHBEIN 31.

181. See text at notes 148-62.

182. See FisHeEn 1012.

183. Id. at $103 \%$.

184. Id. at $1035-6$.

185. Medical Economics, March, 1952, p. 241.

186. AMIA, Nostrumis and Quachery 314 (2d ed. 1912).

187. Fishbein 1034-8. See also Fishbenz, Fars and Qunckeny is Henlaz (1932).

188. AMIA, Gome to Senvices 42-3 (1952). See also 144 JAMIA 764 (1950) (acknowledging the support of various newspapers and local "Better Business Burcaus" in detection of quackery). 
disease, particularly chiropractic ${ }^{180}$ and osteopathy, ${ }^{100}$ has complicated state medical licensing. Chiropractors are able to acquire licenses to practice in nearly all states ${ }^{191}$ but, due to strenuous opposition from state medical societies and the AMA, theirs is a limited privilege. Usually the practice acts restrict treatment by a chiropractor to manual adjustment of the spinal column and forbid administering or prescribing drugs, puncturing the skin, or practicing obstetrics. ${ }^{102}$ A few states limit the osteopath to almost the same narrow privileges granted chiropractors, ${ }^{103}$ but most allow him to administer drugs or to perform surgery, although only upon a showing of additional special training. ${ }^{104}$ Several states license the osteopath for the same unrestricted practice as the M.D. ${ }^{195}$

Despite limitations, these groups continue to provide the medical profession with active competition. Each year, two million Americans consult one of the nation's 32,000 licensed chiropractors for the first time. ${ }^{100}$ There are over 11,000 licensed osteopaths in the United States $;{ }^{107}$ they maintain fully equipped hospitals ${ }^{108}$ they sometimes serve in city and state health departments..$^{100}$

189. "A system of therapeutics based upon the theory that disease is cattsed by inter" ference with nerve function. Its theory is based upon the premise that all other systems and physiologic processes of the human body are controlled and co-ordinated by the nerve system. Its therapeutics attempts to restore normal function of the nerve system by manipulation and treatment of the structures of the human body, especially those of the spinal column." Definition of chiropractic adopted by National Chiropractic Association, quoted in 6 EnCYCLOPEDia AMrericana 567 (1948).

190. "Osteopathy is that school of medicine the distinguishing fenture of which is found in its emphasis upon the importance of normal body mechanics for health, and upon manipulation to detect and correct faulty relations of the body parts to restore health." 21 id. 28-30. The osteopathic premise is that upon removal of mechanical "or other" interferences the physiological functions will normalize themselves, i.c., the forces are present in the human body to develop a natural immunity to disease. 21 id. 31-33.

191. Louisiana, Massachusetts, Mississippi, and New York do not provide for licensure of chiropractors in their Medical Practice Acts. In Massachusetts and New York this is apparently taken to mean that a chiropractor may practice qua chiropractor provided he meets the standards set for a Doctor of Medicine. AMA, Scops of CHikoprisctic Practice in the United States (mimeo survey of state laws relating to chiropractors, 1947) (copy on file in Yale Law Library). The Louisiana and Mississippi licensing bodies do not recognize chiropractic as a profession within their states. Ibid.

192. E.g., Ala. Code tit. 46, $\$ 259$ (1940); 5 ArIz. Code AnN. $\$ 67-704$ (1939); W. VA. CODE $\$ \$ 3005-6,300 \$$ (1949).

193. E.g., Ill. Ann. Stat. c. 91, §5 (Smith-Hurd, 1948); Code S. Car. \$56-1101 (1952).

194. E.g., Ark. Stat. Ann. \$72-906 (1947) ; Iowa Code ANn. $\$ \$ 150.4-5$ (1949); Rev. Codes Mont. $\S 66-1406$ (1947). See American Medical Ass'n Daily Bulletin, June 12, 1952, p. 1, col. 2.

195. E.g., D.C. Code Ann. §2-109 (1951) ; INd. Stat. \$63-1316 (Burns, 1951).

196. Encyclopedia Americana Annual 137 (1950).

197. Id. at 520 .

198. See, e.g., Statement of Ralph Copeland, D.O., in 5 MaGnuson Rep. 335, 336 (reporting 38 osteopathic hospitals in California); N.Y. Times, March 9, 1954, p. 29, col. 2 (reporting purchase by osteopaths of a New York sanatorium).

199. Statement of Ralph Copeland, D.O., in 5 MAGNuson REP. 335, 337. 
And, although organized medicine's justification for limited licensing of the "cults" is expressed in terms of protecting the consumer from unqualified practitioners, there may also be present an element of self-protection from this economic encroachment.

Organized medicine's campaign against the chiropractor is presently a battle of containment. In four states the requirements for licensing are the same as those for a Doctor of Medicine; practically, the chiropractor has been excluded. ${ }^{200}$ Elsewhere, medical societies police the legal boundaries of a chiropractor's limited license and oppose legislative extension of his privilege. ${ }^{201}$

Basic Science requirements, although originally designed as a method of raising the standards of medical practice generally, ${ }^{202}$ are a weapon of great potential in organized medicine's struggle against chiropractic and other limited healing arts. But it is a weapon that has thus far failed. These requirements, adopted by law in nineteen states and the District of Columbia, ${ }^{203}$ direct all applicants for any healing art licensure to pass examinations in anatomy, physiology, chemistry, bacteriology, and pathology. But often the examination taken by candidates for medical licensure is different from the chiropractic basic science test. ${ }^{204}$ Medical men have termed the chiropractic basic science exam a "farce."20s Consequently, the AMIA has proposed a Uniform Basic Science Act, ${ }^{208}$ applicable to "nonsectarian medicine, osteopathy, chiropractic, naturopathy, sanipractic, and other modes of healing."207 AMA's stand is: "Whatever may be said of separate licensing boards for the nonsectarian practitioner and the cultists, there seems to be no valid argument against a uniform examination in the basic sciences." 20 Widespread adoption of this Act could mean the end of the cults' challenge to organized medicine..$^{203}$

Recently, the National Chiropractic Association has engaged the AMA in a top-level clash of competing interest groups. The NCA was successful in having chiropractic colleges certified for the G. I. Bill; by 1949 the Government had paid the tuition of 1700 veterans studying chiropractic.210 And now the NCA is campaigning for Veterans Administration recognition of-and

200. See note 191 supra. Doyle, Sctence vs. Cangorractic 15 (1953); $f$. Citizeis' Healte Education Consittee, What Price Your Life? (1952).

201. See, e.g., Medical Economics, May, 1952, p. 237 (chiropractor fined \$lo00 for "mislabeling" a radiotherapeutic device, after complaint by medical organization); Crrtzens' Health Edccation Consuitres, op. cit. supra note 200 (Mledical Society of the State of New York statement against chiropractic licensing).

202. DOYLE, op. cit. supra note 12, at 10-11.

203. AMA, Analysis of Basic Science Laws (1940); id. (Supps. I-III 1945, 1948, 1949).

204. See, e.g., 140 JAMA 229 (1949).

205. Ibid.

206. Alia, Draft of Proposed Basic Science Act (undated) (copy on file in Yale Law Library).

207. Id. $\$ 2$ Note.

208. Id. $\$ 1$ Note.

209. See Doyle, op. cit. supra note 200 , at 10 .

210. 140 JAMIA 229 (1949). 
reimbursement for-chiropractic care. ${ }^{211}$ In 1950 AMA spokesmen appeared before the House Veterans' Affairs Committee and helped defeat this proposal, arguing that chiropractic does not recognize the bacterial theory of disease, is not taught at any university or college supported by public funds, and therefore should not be recognized by the VA. ${ }^{212}$ So the NCA has moved the fight to the American Legion, from which it has sought backing. ${ }^{.13}$ Thereupon the AMA urged its member veterans to become active Legionnaires in order to forestall any possible pressure from an organization equipped with lobbying power on a par with its own. ${ }^{214}$

Historically, organized medicine's struggle to limit the practice of osteopathy took the same form as that against the chiropractors. Courts have upheld the constitutionality of AMA-fostered differentials in licensing privileges granted an M.D. and a D. O. despite apparent similarity of training. ${ }^{216}$ Furthermore, the United States Supreme Court has upheld the right of governing boards of public (and a fortiori of private) hospitals to deny osteopaths use of their facilities. ${ }^{216}$ And hospitals seeking AMA accreditation for internship and residency training usually must bar osteopaths from their staffs. ${ }^{217}$

Recently, the city council of Bay City, Michigan, voted to allow osteopaths to use municipal hospital facilities. ${ }^{218}$ The 70 staff M.D.'s then walked out rather than "jeopardize their own ethical standings," and the AMA Council on Medical Education and Hospitals immediately withdrew registration and "Approval" of the hospital. The struggle between local physicians and osteopaths was finally resolved by a referendum in which the voters chose nearly 3 to 1 to exclude osteopaths from their city's hospital staff..$^{210}$

An important recent change in the AMA attitude toward osteopaths has been a policy tending toward their absorption into the medical profession. Precedent for this trend exists in the case of the homeopathic ${ }^{220}$ physicians,

211. 143 JAMA 659 (1950); Weintrob, Chiropractors Plan V.A. Coup, Medical Economics, Jan., 1953, p. 115.

212. 143 JAMA 659 (1950).

213. Weintrob, supra note 211.

214. Id. at 123.

215. Cf. Watson v. Maryland, 218 U.S. 173 (1910); Dent v. West Virginia, 129 U.S. 114 (1889) ; see Polhemus v. American Medical Association, 145 F.2d 357, 359 (10th Cir. 1944).

216. Hayman v. City of Galveston, 273 U.S. 414 (1927). See also Newton v. Board of Comm'rs of Weld County, 86 Colo. 446, 282 Pac. 1068 (1929). Cf. Statement of Dr. Roger E. Bennett, in 5 Magnuson Rep. 332, 333; Statement of Dr. William A. Brandt, in 5 id. 334-5.

217. 151 JAMA 579, 581 (1953) (staffs of accredited hospitals should be composed of graduates of approved medical schools). But cf. text at note 224 infra; Statement of Ralph Copeland, D.O., in 5 MAGNuson Rep. 335, 336 (reporting several California hospitals with unified M.D.-D.O. staffs).

218. Fuller, M.D.'s Battle It Out With D.O.'s, Medical Economics, Sept., 1952, p. 71.

219. Medical Economics, Jan., 1953, p. 11.

220. See 14 Encxclopedia Americana 342 (1948) (homceopathy: "[T] he treatment of disease by means of its similimum. The cure is undertaken by a medicine capable of producing in a healthy person symptoms similar to those manifested by the patient."). 
who formerly were considered cultists ${ }^{221}$ but who now have "Approved" medical schools, ${ }^{222}$ unlimited rights of practice, and membership in the AMA. Evidence of a similar policy toward osteopaths is clear. Although the AMIA code of ethics provides that "[a]1l voluntarily associated activities with cultists are unethical,"223 the Judicial Council has recently approved limited medical consultation with osteopaths, as well as sharing facilities with them in "small, outlying hospitals." 224 In many states, medical society-sponsored Blue Shield plans allow osteopaths to participate. 295 A resolution urging immediate action toward an "eventual amalgamation" of medicine and osteopathy was voted down by the House of Delegates, 290 yet AMA and AOA leaders have conferred with amalgamation in mind. .22

The basis for amalgamation is the present approximation of medical standards by osteopathic schools. ${ }^{228}$ The osteopathic curriculum is nearly the same as the medical, but includes osteopathic science, which to the AIIA carries the "stigma of cultism."229 Virtual abandonment of this teaching would probably permit MI.D.'s to instruct in osteopathic schools, leading to eventual "Approval." 230 Indeed, osteopathic services are already approved by the Veterans Administration and the United States Public Health Service.201

But AMA approval seems to depend upon economic as well as strictly medical factors. Amalgamation is opposed in rural states where general practice prevails and the osteopath provides strong competition to the physician..$^{322}$ Support for amalgamation comes from large urban centers where specialists dominate medical practice. ${ }^{233}$ Probably a continued high demand for medical services, mitigating competition, will accelerate organized medicine's acceptance of the osteopath as an equal.

221. See, e.g., FisHBEIN 62, 96 .

222. E.g., Hahnemann Medical College, Philadelphia, Pa, 150 JAAIA 105 (1952).

223. AMIA, Paixciples of Miedical Ethics c. $2, \$ 1$.

224. Medical Economics, Dec., 1952, p. 65.

225. Id., Aug., 1952, p. 65; id., April, 1952, p. 15. See also, c.g., Statement of Dr. William A. Brandt, 5 MAGNuson ReP. 334, 335.

226. I1edical Economics, Aug., 1952, p. 65.

227. Ibid.

228. Ibid.; Address of John W. Cline, M.D., President of the AMA, to the House of Delegates, June 9, 1952 (mimeo. press relcase on file in Yale Law Library). See also Statement of Dr. Stephen A. Sheppard, in 5 Magnusox Rep. 331, 332.

229. Address of John W. Cline, MI.D., suprà note 238 .

230. Ibid.

231. Miedical Economics, Aug., 1952, p. 65. See also Statement of Ralph Copeland, D.O., in 5 Magnuson Rep. 335, 336 (College of Osteupathic Physicians and Surgeons in Los Angeles received Federal grants for use in cancer teaching prugram); Statement of Lawrence D. Jones, 5 id. 337, 338 (same, in Missouri osteopathic schools).

232. Medical Economics, Aug., 1952, p. 65. See also Statement of Lawrence D. Jones, 5 Magiuson Rep. 337 (showing extent of osteopathic practice in Missouri). See also Medical Economics, July, 1952, p. 25 (letter from M.D. in small Oregun town, complaining that osteopaths dominate general practice and leave "neither room nor work cnough for M.D.'s").

233. Mredical Economics, Aug., 1952, p. 65. 
Psychologists. Originally the practice of medicine was limited to the care of physical disturbances; many state medical practice acts still do not specifically require licensure for the treatment of behavioral or mental disorders. ${ }^{234}$ Both medical and non-medical specialists have contributed to knowledge in the behavioral sciences. The psychiatrist claims exclusive jurisdiction in diagnosis and treatment of mental disease, ${ }^{235}$ asserting that his medical training gives him physiological knowledge requisite to an appreciation of the patient's overall condition..$^{236} \mathrm{He}$ regards the psychologist's role as ancillary, similar to that of the nurse or X-ray technician. ${ }^{237}$ Psychologists, who presently provide many diagnostic and therapeutic services to mental patients, ${ }^{238}$ do not agree that psychotherapy should be the sole province of the M.D.'s.230

The American Psychological Association, much like the AMA, has attempted to raise the level of psychological practice. ${ }^{240}$ Since many states do not regulate the treatment of mental disorders, unqualified persons hold themselves out as competent psychologists. ${ }^{241}$ To set the qualified practitioner apart, many psychologists have urged passage of certification acts, ${ }^{242}$ whereby those meeting educational requirements and passing examinations may receive the privilege of calling themselves "Certified Psychologists."243 These acts, adopted in only a few states, do not limit psychological practice to those certified, but they do provide the public with a possible guide to competence. ${ }^{244}$ Bills have also been proposed in a few jurisdictions requiring licensure of psychologists and prohibiting practice by those not meeting prescribed standards. ${ }^{246}$ But psychiatrists, fearing that their sphere of competence might be invaded, have

234. See, e.g., N.Y. ED. Law $\S 6513(2)$ (c) : “A person practices medicine . . . who holds himself out as being able to diagnose, treat, operate or prescribe for any human disease, pain, injury, deformity or physical condition. . .." See also compilation and analysis of statutes in Note, Regulation of Psychological Counseling and Psychothcraty, 51 CoL. L. Rev. 474, 475-8 (1951).

235. Letter, Defining Medical Practice, N.Y. Times, March 1, 1954, p. 24, col. 6; Statement of the American Psychiatric Association's Position on Amending State Medical Practice Acts and Related Matters (1954) (copy on file in Yale Law Library).

236. Ibid.

237. Ibid.

238. Sanford, Annual Report of the Executive Secretary: 1952, 7 Am. PsYcholoust 686 (1952).

239. Letter, Restricting Psychologists, N.Y. Times, Feb. 18, 1954, p. 30, col. 6.

240. Sanford, supra note 238 , at 690 . See also N.Y. Times, Sept. 1, 1952, p. 19, col. 8 (adoption of code of ethics).

241. See David, An Analysis of Psychologists in the Classified Telephone Dirctory, 3 Am. Psychologist 133 (1948) ; N.Y. Times, March 17, 1951, p. 17, col. 5; id., March 31, 1951, p. 14, col. 3; Note, supra note 234 .

242. See Saffr, Certification versus Licensing Legislation, 5 Am. Psycholoctst 105 (1950); The Certification of Clinical Psychologists in Virginia, 1 id. at 395 (1946).

243. See, e.g., Conn. Gen. Stat. \$\$ 4632-8 (1949) ; Ky. Rev. Stat. AnN. \$§ 319.010319.990 (Cum. Supp. 1951).

244. See Note, supra note 234 , at $482-5$.

245. E.g., N.Y. Assembly, Nos. 2099, 3432 (Feb. 12, 1951); Pa. Senatc, No. 848 (April 5, 1949). 
secured the support of organized medicine to defeat these measures. Governor Dewey vetoed the New York licensing bill and cited the "vigorous and impressive objections" of the state medical society and American Psychiatric Association. ${ }^{246}$ After this setback, the psychologists refrained from seeking legislation pending conferences with the medical profession designed to define each profession's scope of competency. ${ }^{247}$

Recently, however, the psychiatrists have taken affirmative action to prevent the further encroachment of non-medical practitioners. The Medical Society of the State of New York, in cooperation with psychiatric groups, has unsuccessfully sought revision of the New York medical practice act to make only the M.D. competent to treat "mental and nervous disorders."-28 Both the American Psychiatric Association ${ }^{240}$ and the AMA ${ }^{250}$ favor such legislation. But these laws would freeze the status of two professions which often worl: in a flexible and cooperative relationship. Under such circumstances, joint efforts to define each specialty's qualifications should be encouraged. This would leave both groups free to cooperate in eliminating the unqualified practice of psychotherapy.

\section{Controlling the quality and supply of doctors}

Another key function of the AMIA is its inspection of medical schools and its annual listing of those approved. ${ }^{251}$ All states require that an applicant for medical licensure be a graduate of an acceptable medical school.2:2 Standards of acceptability are set by statute, or by formal rule or informal policy of the state medical examining boards. ${ }^{253}$ These statutes or rules provide that the board will consider only graduates of schools approved by the AMIA and/or the American Association of Medical Colleges, whose lists are identical. 231

246. N.Y. Times, April 12, 1951, p. 26, col. 5. See also Telegram from Daniel Blain, MI.D., Mledical Director, American Psychiatric Association, to Gorernor Thomas E. Dewey, dated March 21, 1951, copy on file in Yale Law Library.

247. Letter, sitpra note 239.

248. Egan, Medical Plan Stirs State Controuirsy, N.Y. Times, Feb. 21, 1954, §4, p. 7, cols. 1-5; Letter, supra note 235.

249. Egan, supra note 248; Newsletter of the Axr. Psyculatric Ass': (February, 1953).

250. 150 JAMIA 1687 (1952) (Regort of AMA Committee on MIental Health): "It is deemed advisable that all medical practice acts include the treatment of illness by psychological methods. It is further recommended that the American Miedieal Assuciatiun take active steps toward this end."

251. See 150 JAMA 99-138 (1952) for an example of the complete test of an Annual Report on Medical Education by the Council on Jledical Education and Hospitals of the AMA. The Report contains, as well as the approved list, an analysis uf trends in medical school enrollment, developments in curriculum, medical school finances, forcign medical schools and students, and a variety of other related matters.

252. 149 JAMIA 466 (1952). In addition to professional seheol requirements, all states require completion of at least two years of college, and 31 boards demand at least one year of internship. Itid.

253. Ibid.

254. Twenty-nine boards require approval by both the AMA and AAMC, nincteen 
Since it is impossible for each state board to make an independent inspection of every medical school whose graduates apply for licensure, these boards must rely on an outside agency. The AMA fulfills this need and its list thereby acquires the force of law.

Through their reliance upon the AMA to inspect the nation's medical schools, the states tacitly confer upon it the power to set the standards for approval. These standards, of course, fix the quality of medical education, but they also indirectly determine the size of classes in each school. ${ }^{265}$ Maximum student/faculty or student/cadaver ratios, ${ }^{250}$ for example, make expansion costly.

Moreover, many states require a medical school graduate to serve an internship in an approved hospital as an additional training requirement. 267 Again, practical considerations require licensing boards to utilize the AMA standards and list of approved hospitals. ${ }^{258}$ AMA approval is vital to a hospital; without it, the hospital cannot obtain the low-cost services of interns. ${ }^{260}$ This power gives organized medicine a device to enforce conformity with policies occasionally unrelated to medical training. ${ }^{260}$

Medical Education. The improvement of medical education was one motive for the founding of the American Medical Association. ${ }^{201}$ Early attempts, however, were not successful. ${ }^{262}$ In 1910, the Carnegie Foundation's Flexner Report publicized the serious inadequacy of many of the medical schools in

by the AMA alone, two by the AAMC, and three jurisdictions maintain their own lists (figures include the District of Columbia and American possessions). Id at 466-7.

There have been minor differences in listings in the past, mostly concerning two-ycar basic science schools and Canadian medical colleges. See 105 JAMA 682 (1935). However, the two organizations have cooperated closely in setting standards and making inspections. FISHBEIN 912-16.

255. See 10 AAMC JournaL 191 (1935); cf. 146 JAMA 865 (1951) (AMA asserts it does not attempt to control size of medical school classes, but it may advise a school to decrease its size when a larger enrollment might mean a lowering of standards).

256. AMA, Essentials of an Acceptable Medical Schoor 3 (1951) (other requirements concern manner of faculty appointments, library and other physical plant, clinical facilities, financial resources, admission standards, and' curriculum). The EsSENTIALS have recently been revised in some respects. See 148 JAMA 374 (1952).

257. See supra note 252.

258. See 150 JAMA 275-377 (1952) for an example of the complete text of an Annual Report on Internships and Residencies by the Council on Medical Education and Hospitals of the AMA. See note 259 infra.

259. Some states maintain an independent inspection and approval list for hospitals within their jurisdictions, and in a few instances, the board requires the applicant to have served his internship within the state. 150 JAMA 466 (1952). But the state rarely accredits a hospital not approved by the AMA. Therefore, generally, to attract interns, the hospital must meet AMA standards, regardless of the separate state inspection.

260. For examples of AMA pressures upon hospitals sec note 93 supra, notes 425,429 infra and accompanying text.

261. Fismbein 30; Johnson, The Council on Medical Education and Hospitals in FISHBEIN 887.

262. Johnson, supra note 261, at 888-90; Cline, Medical Education and the Medical Profession, 148 JAMA 1273 (1952). 
the country. ${ }^{263}$ Strong public opinion and state medical association pressure has since forced state examining boards and medical schools to recognize the standards set by the AMA Council on Miedical Education. 20 Although 81 substandard schools have been forced out of existence, some formerly inadequate schools have managed to survive by rapidly improving in quality. ${ }^{205}$ Today there are 79 medical schools in the United States, all "approved."

When adoption of AIIA requirements forced disapproved medical schools to close, the annual graduating class of doctors was cut in half. ${ }^{067}$ But these numerical losses have been recouped. Existing schools have gradually expanded their facilities to a point where annual output exceeds the 1910 level. ${ }^{268}$ For the past five years, each freshman class has surpassed the previous year's record-breaking enrollment. ${ }^{269}$ The AMA has provided technical assistance to schools planning expansion. ${ }^{2 \pi 0}$ And state societies have sometimes advocated the formation of new medical schools, as in MIaine and New Jersey, or supported the conversion of two-year "basic science" schools into full fouryear schools, as in North Carolina and West Virginia."71 The resulting increase in physician supply has raised the American doctor/patient ratio to 136 per 100,000 , second only to Israel with its large number of refugee Jewish physicians. ${ }^{272}$ This ratio is expected to hold despite rapid population gains. ${ }^{273}$

But the AMIA has not consistently pursued a policy of increasing the doctor supply. Moved by a desire to mitigate competition among doctors during the

263. Flexwer, Miedical Education in the United States and Camada (1910). For the cooperative role played by the newly-formed AMA Council on Afedieal Edueation in assisting Dr. Flexner, see Johnson, supra note 261, at \$97-9.

264. Id. at 898-9.

265. Id. at 898 .

266. Originally the AMA's classification system included class A (approved), class B (probation), or class C (unapproved) ratings. Upon the elimination of the class $C$ schools, the categories were changed to "Approved" or "Unapproved." The current list of Approved schools is reported in 153 JAMA 114-16 (1953). The list includes 72 fouryear schools of medicine and 7 two-year basic medical science schools.

267. Cf. 142 JAMIA 420 (1950).

268. Ibid. The number of graduates leaving Approved (Class A) schools annually has doubled since 1910 .

269. 153 JAMA 118 (1953). Enrollment for the 72 medical and 7 basic science schools for the 1952-3 academic year was 27,688; 6475 were members of the graduating class.

270. 146 JAMA 865 (1951) ; Cline, supra note 262, at 1274 .

271. Ibid. See also, e.g., Bangor (Me) Commercial, June 20, 1951 (retiring president of Maine Medical Association urges $\$ 50,000$ society fund to assist in establishment of medical school in Maine); 45 W. VA. MEn. J. 262 (1949) (resolution of state sucicty favoring efforts to establish four-year school to alleviate shortage of doctors in Vest Virginia) ; 13 Penlatrics $\$ 9$ (1954) (recounting conflict between Medical Society of the State of North Carolina and AMA concerning expansion to four-year seliool).

272. 3 Magnoson Rep. 135; 1 Health Manfower Source Bow 20 (Federal Security Agency 1948).

273. 1. Magnuson Rep. 12. See also 146 JAMIA $\$ 65$ (1951). 
depression, the Association attempted to reduce medical school enrollments. By 1932 the AAMC and AMA had become alarmed about an increasing "surplus of doctors."274 In 1933 the AMA Council on Medical Education invited the "active support of the Association of American Medical Colleges in bringing about a substantial reduction of their enrolment."275 The Council's secretary, in a speech before the AAMC, mentioned the alleged surplus of doctors and deplored the practice of making up classes in medical schools "without any regard to the needs of the profession or of the country as a whole."270 He concluded: "The time has come when we must still further limit the enrollment of our medical schools."277 By 1934 the Council could report that

274. The AAMC's Committee on Medical Education in 1932 reported an excess of 25,000 physicians. These figures were based upon the fact that the American patient/ physician ratio was lower than Europe's. AAMC, Final Rep. of the CoMm. on Meil. Ev. (1932), abstracted in 99 JAMA 2206 (1932). The Committee feared that "there are indications that [the oversupply] will increase." $99 \mathrm{id}$. at 2035-6. The AMA echoed the AAMC's fears in commenting editorially upon the AAMC Report: "These are facts which have been emphasized repeatedly in the columns of THE JourNal, and means must be developed for correcting this situation." Ibid. Indeed, the Journal had already considered the problem of oversupply. See, e.g., $99 \mathrm{id}$. at 765 (Editorial: "Perhaps there is need for professional birth control."). See also Beasley, Economic Status of the Mclical Profession, $99 \mathrm{id}$. at 1358 . Dr. Beasley suggested a reduction of enrollments by $25 \%$ per year until a patient/physician ratio of $2000 / 1$ is reached. He concluded:

"This must be done or the practice of medicine must be turned over to the government. The government will employ only a sufficient number to do the work. ... What will those of us who are not in the employ of the government do? The answer is simple-We shall of necessity be forced to seek other employment."

275. Report of the AMA Council on Medical Education and Hospitals, 100 JAMA 1425 (1933). The Council's Report again emphasized the AMA's fear that the doctor surplus was growing, since the number of graduates exceeded the number of physician deaths, and since the increase exceeded the rate of population growth. Ibid.

276. Quoted in GreEnberg, Medictine in CRISIs 17 (Reprinted from Providence Journal and Evening Bulletin, March, 1951, copy on file in Yale Law Library). See also 101 JAMA 42 (1933) (Resolution passed by Medical Society of the State of New York, urging the AMA to investigate the oversupply of physicians and to "use its influence to bring about a limitation of the number of medical matriculants, and hence of medical graduates.").

277. GREenberG, op. cit. supra note 276, at 17. See also 100 JAMA 198 (1933) (AAMC announces policy against licensure of foreign-educated M.D.'s); 9 AAMC Journal 30 (1934) (statement of AMA President-Elect: "The limitation of schools is possible, and here the Council on Medical Education of the American Medical Association can do much. There can also be a distinct curtailment of certain schools.").

See Bevan, The Over-Croceding of the Medical Profession, 11 AAMC Jounnat 377 (1936). Dr. Bevan, a former AMA Committee on Medical Education Chairman, announced:

"The evidence obtainable shows a definite overcrowding of the medical profession. Both the people and the medical profession would be much better off if by a well-organized plan the poorer qualified and least desirable 10 or 15 per cent of the medical practitioners could gradually be eliminated. . . .

"To accomplish this, we must elevate the standards of requirements demanded to secure a medical education and a license to practice medicinc.... 
several schools were decreasing enrollments in "adherence to the Council's principles."278

Even today, AMIA's limited support ${ }^{279}$ for expansion in medical education may not be adequate to meet growing demand for physicians. Increased military needs, coupled with expanded public health programs and private requirements, have created a doctor shortage which is becoming progressively more acute. 280 Estimates of the adequacy of the doctor supply by 1980 vary greatly, depending on an intangible variable: "desirable level of medical care." 31 Maldistribution of physicians, resulting from the emphasis on specialization and the concentration of physicians in urban centers, has compounded the shortage. ${ }^{252}$ Local action by doctor-needy communities-guarantees and special inducements to young graduates seeking a location-may be a partial solution. ${ }^{283}$ Local and state medical society scholarships, granted on the stipulation that the recipient will practice in a small community, have also helped. ${ }^{284}$ A recent AMA campaign glorifying the general practitioner may

The American Medical Association has already demonstrated its ability to reduce the number of medical students by elevating the educational requirements." 11 id. at 379-80.

278. GReENBerg, op. cit. sipra note 276 , at 17 . See also Bevan, sipra note 277 , at 381:: "This [the size of the nation's 1935 freshman medical class] is a falling of of 584. This is a most encouraging sign and is due to the efforts of the Council on Medieal Education of the American Medical Association and the Association of American Medical Schools and the Federation of State Miedical Buards."

279. See, e.g., 136 JAMLA 626 (1948) ; 142 JAMLA 420 (1950); notes 270-1 supro and accompanying text. See also text at notes 547, 552-60 infro.

280. 1 MLAGNuSON ReP. 11-13.

281. See, e.g., Maisel, Our Alarming Doctor Shortagc, Collier's, Dec. 16, 1950, p. 18 (quoting (1) an AMA official who stated, in 1945, that medieal education could produce only half of the 35,000 physicians needed after World War II; (2) another AMIA officer to the effect that the 1960 shortage would not exceed 15,000 physicians) ; Mou:m: PE:nell \& Berger, Health Seruce Areas: Estmintes of Future Pnysicini Requirearents (U.S. Pub. Health Service Bull. No. 305, 1949) (shortage by 1960 of 17,000 to 45,000 depending upon which of three standards is applied); 142 JAIIA 111-112 (1950) (all three standards "unrealistic": possible 1960 surplus foreseen); de Kruif, II"hat About This "Doctor Shortage," Reader's Digest, June, 1951, p. 24 (no shortage); N.Y. Times, Feb. 14, 1951, p. 31, col. 5 (AMA official sees surplus "more likely" than deficit due to increased productivity of physicians); id., Feb. 1S, 1951, p. 58, cols. 3-4 (conclusion of Health Resources Advisory Committee of the National Security Resources Board: shortage of 22,000 physicians by 1954) ; 1 MLagnuson Rep. 13 (conclusion of President's Commission on the Health Needs of the Nation: shortage of 22,000 physicians by 1960 ).

282. 3 MLAGNUSON Rep. 136-9; cf. 1 id. at 12; de Kruif, supra note 281, at 25. But see Dickinson \& Bradley, Cosiparisons of State Physicuar-Popllation: Rutios fo. 1938 AND 1949 (AMA Bureau of Med. Econ. Research Bull. No. 78, 1950) (citing inprovement in distribution of physicians) ; N.Y. Times, Feb. 9, 1954, p. 29, col. 8 (reporting AMA's current study disclosing that doctors are "well distributed throughout the United States.").

283. de Kruif, supra note 281, at 26-7.

284. See, e.g., 146 JAMA 205, 855, 1423 (1951); Questonmairs. No. 47 (several societies report scholarship or loan funds). 
have some effect. ${ }^{285}$ But the need for long-term regional or nation-wide planning of the supply and distribution of doctors has not been met under AMA guidance. $^{286}$

Indeed, the wisdom of lodging quasi-legal authority over medical schools in the AMA may also be open to question. Without doubt, the quality of medical education has improved enormously under AMA guidance. And experienced medical educators and practitioners are best fitted to adjust standards to the needs and potentialities of the school and student. But the power to determine supply, which resides inevitably within the power to set standards, should not rest solely in the hands of a private group which is neither directly responsible to the public nor necessarily responsive to the nation's requirements.

Licensing of foreign-trained doctors. The establishment of licensure requirements for foreign-trained physicians was not a pressing problem until the late 1930's. ${ }^{287}$ With the rise and spread of European totalitarianism, however, the states received an increasing number of requests for recognition of foreign credentials. ${ }^{288}$ Today there are few displaced European physicians left. ${ }^{289}$ But in their place increasing numbers of Americans, unable to gain

285. See, e.g., 152 JAMA 843, 1105 (1953).

286. Bevan, supra note 277 , at 377 :

"It became perfectly clear, when the problem was analyzed, that we needed a national influence and control, and that under our constitutional form of government this could not be exercised by the Federal Government because the right to decide who should practice medicine belonged to the individual states.

"It was felt that the best solution was for the American Medical Association to assume this function of national influence and control."

For one view of the effect of this tacit delegation of power see OFFICIAL REPORT of the Medical Care Commission on the Expansion of the Medical School of thie University of Norte Carolina 108 (1947), reprinted in 13 Pediatrics 91 (1954):

"It is the function of the Council on Medical Education and Hospitals of the American Medical Association to be concerned with the national situation in regard to total personnel supply and hospital beds and with elevation of standards in medical schools and hospitals. However, past experience has shown that the Council-just as the official American Medical Association body-has been prone to generalize and has shown little concern in local state inadequacies in hospitals, medical education, and distribution of medical care. It is too content to sit complacently, often with ears and eyes closed, and glory in the greatness of the contributions of American medicine-of which we are all justly proud. It has shown a disappointing lack of leadership with vision and courage in trying new methods of providing medical care or in improving medical education. For it the traditional has become the perfect way."

287. Davie, Refugers in America 257 (1947) (average of 535 physicians and dentists admitted to the United States annually from 1932 to 1944); note 277 supro. But see Refugees, Unlimited, Medical Economics, Feb., 1939, p. 24 ("coming in droves").

288. Cf. Davie, op. cit. supra note 287 , at 261.

289. Ibid.; Burgess, Resettlement of the Displaced Physician in the United Stat's, 143 JAMA 413 (1950). 
admission to medical schools at home, have gone abroad to study and now seek accreditation. 290

The official attitude of the state examining boards toward foreign-trained doctors has largely been the result of state medical society and AMI policies. ${ }^{291}$ By the 1930's, 22 states would not accept foreign physicians at all. ${ }^{292}$ In several others, full citizenship and additional training requirements achieved the same purpose. ${ }^{203}$ The exclusion of refugee physicians was accomplished over the protest of farmer and labor medical cooperatives, particularly in states suffering from doctor shortages. 208

Since the war, the AMIA Council on Medical Education has established a less restrictive policy toward foreign medical school graduates..205 The ANIA and AANC have jointly issued a list of 50 European schools which they suggest for state board acceptance. ${ }^{206}$ But the list does not include institutions from which refugee doctors are likely to come-those of Germany and Austria. ${ }^{297}$ For these doctors an ANIA spokesman has recommended adoption of the procedure followed by the Iowa Board of Miedical Examiners. ${ }^{203}$ There the foreign doctor is placed as an assistant in a state institution for one year during which he receives supervision, refresher courses, and grades from his physicians-in-charge. At the end of his trial period, his file is considered by the State Board and he is accepted or rejected.

It is of great importance to American students educated abroad that twentythree licensing boards have reported willingness to consider graduates of foreign schools recommended by the AMA..209 But, despite the AMIA's insistence that the list is "tentative" and that "[a]bsence of a school from the list does not necessarily imply disapproval,"300 the tendency among these boards has been to consider only graduates of already approved schools. ${ }^{301} Y$ et, of the 1121 American students in foreign schools in 1951, only half were enrolled in approved schools. ${ }^{302}$ Furthermore, 11 states still do not accept any foreign credits. ${ }^{303}$ And even in states which do allow foreign graduates to talie the

290. 150 JAMA 125 (1952).

291. DaVIE, op. cit. supra note 287, at 265, 267; cf. Note, Refugees and tic Professions, 53 HARv. L. REv. 112, 114 (1939). However, some local and state societies have advocated liberalization in licensure of emigré doctors. See, c.g., N.Y. Times, Feb. 21, 1942, p. 7, col. 4; id., MIar. 9, 1943, p. 22, col. 2; id., April 25, 1943, p. 31, col. 3.

292. Burgess, supra note 289, at 415.

293. DAvIE, op. cit. supra note 2S7, at 267-76; Note, sufra note 291, at 113-114.

294. S5 Survey 592 (1949); Toledo Blade, Feb. 18, 1950 (Editorial, "The Little Fishbeins," scores Wisconsin doctors for "arbitrary attitudes" toward forcign-edueated physicians).

295. 139 JAMA 1080 (1949); 142 JAMA 587 (1950); 150 JAMIA 125 (1952).

296. 153 JAMIA 133 (1953).

297. Ibid.

298. Burgess, supra note 289, at 415.

299. 149 JAMIA 470 (1952).

300. 150 JAMA 125 (1952).

301. 149 JAMA 470 (1952).

302. Prcceenings, 48th Ann. Cong. on Jied. Educition \& Lice:ssure 26 (1952).

303. 149 JAMIA 470 (1952). See also N.Y. Times, May 19, 1954, p. 33, col. 7. 
Board examinations, the percentage of failures among them has been high. ${ }^{304}$ A European medical education is still not a reliable path to licensure in the United States.

\section{Determining the Conditions of Practice and Payment}

The AMA "Principles of Medical Ethics" 305 is a codification of the doctor's professional conscience as well as a blueprint for the organization of medical practice. In theory, the principles are not "laws to govern" but rather "guides to correct conduct." 306 However, for the doctor they approach legal status since unethical conduct is a ground for expulsion from every county medical society. ${ }^{307}$ The code regulates, in general terms, a wide range of the doctor's conduct, toward his patients, ${ }^{308}$ other physicians, ${ }^{300}$ and the public at large..$^{310}$ Thus it is applicable to most matters affecting medical practice.

This code of ethics is geared to the typical unit of medical practice in America-the individual practitioner, remunerated on the basis of a fee for service rendered. But the pressure of changed conditions is forcing modifications in this pattern. Increased medical knowledge and new techniques have created the specialties, with consequent increased interdependence among doctors; much modern medicine is practiced by a team rather than by a lone practitioner. The need for expensive equipment and reliance upon technicians has made individual entrepreneurship difficult; hospitals, medical consumer organizations, and groups of doctors-able to supply needed capital-have hired physicians on a salary basis, shifting risk of loss or chance for gain to themselves. And a desire to anticipate unpredictable medical expenses has led the consumer to demand an application of the insurance principle to the cost of sickness. Each of these modifications-group practice, salaried practice, lay sponsorship, and prepayment-is still in the experimental stage.

Throughout this period, organized medicine has resisted or attempted to control change, rather than allow free experimentation. The physicians in positions of power within the AMA have risen to the top of the profession via the individual, fee-for-service system. Any significant change in that system represents a threat to a familiar and tested method of practice.

The AMA has expressed or rationalized its opposition to change in terms of ethics. In so doing it has often failed to meet the economic issues realistically. By counter-proposals, predicated on the fee-for-service system, it has attempted to satisfy the same needs which brought forth the new methods of practice. Organized medicine's purpose has thus been to contain developments

304. 149 JAMA 476 (1952).

305. Reprints of the AMA, Principles of Medical Ethics may be found in AMA, Guide to Services 101 (1952); AMerican Medical Directory (1950).

306. AMA, Principles of Medical Ethics Foreword.

307. See text at notes 69-79 supra.

308. AMA, Principles of Medical Ethics c. 2.

309. Id., c. 3.

310. Id., c: 4. 
within the orthodox pattern. Its effort to do so has called forth all the power at its command.

\section{ITethods of practice}

The vast majority of physicians in the United States practice alone. ${ }^{311}$ Yet group practice ${ }^{312}$ offers advantages both to patient and physicion. ${ }^{313}$ It affords fuller use of, and a chance to spread the cost of, technical equipment and personnel. ${ }^{314}$ The doctor has ready consultation with other specialist-partnersa convenience to the patient, and a means of retaining control of the fee. ${ }^{315}$ Moreover, younger men in the profession, schooled in a dependence upon other members of the medical care team, often favor medical partnerships. ${ }^{310}$

In the almost automatic referral from partner to partner, characteristic of group practice, critics have seen an infringement of the patient's free choice

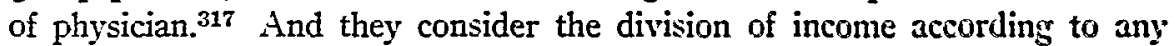
partnership agreement other than value of services rendered, as alkin to fee splitting. ${ }^{318}$ Early groups were disparaged as unethical. ${ }^{310}$ But within recent years active steps have been taken only against those groups offering a plan for some type of flat-fee prepayment. ${ }^{320}$ Rather, the AMIA has mildly discouraged combined practice by repeatedly denying the necessity for, or success of groups. ${ }^{321}$ Its studies have emphasized negative aspects of group prac-

311. Hunt \& Goldstein, Medical Group Frictice in the Uziten States $\&$ (U.S. Pub. Health Service Publication No. 77, 1951) (of 116,795 physicians in private practice in 1946, only 3,084 were engaged in full-time group practice).

312. "Medical group practice is a formal association of three or more physicians providing services in more than one medical field or specialty, with inceme from madieal practice pooled and redistributed to the members according to some prearranged plan." Hunt \& Goldstern, op. cit. supra note 1, at 1. For other definitions of group practice see 2 MAGNuSON REP. 241.

313. Goldmann, Potentialities of Group Practice of 1Icdicine, 10 Cos::. Srume MEn. J. 289 (1946) ; Black \& Skaggs, Partnership Practice: Its Pros and Cons, Mredieal Economics, November, 1952, p. 70. But cf. Hunt, Mfdical Grons Practice is the United States, 237 N. ENG. J. OF MIED. 71, 74 (1947) (citing AMA estimate that the individual general practitioner can adequately care for $85 \%$ of all patients). For a list of advantages and disadvantages of group practice considered most important by physicians, see Hu:is \& GolosTEIN, op. cit. sippra note 311 , at $47-8$.

314. Mieaxs, Doctors, People, and Governarent 71-2 (1953); Goldmann, sufro note 313 , at 290.

315. Hunt \& Goldstein, op. cit. supra note 311, at 46-7; Black \& Slaggs, sispra note 313 , at 72 .

316. 1 Magnuson Rep. 33; N.Y. Acadesty of Mfedicine, Mfentche li: tue ChangING ORDER 139 (1947).

317. Hunt, supra note 313 , at 74 .

318. 3 N.Y. MEDICINE, Feb. 20, 1947, p. 13 (AגIA Judicial Council ruling on division of fees by groups). The AMIA suggested that state or local socicties require a group to file its plan of income division to insure "strict adherence to the ethical principles." Ibid.

319. See, e.g., 99 JAMA 1950 (1932) (labeling groups "guilds or medieal soviets").

320. 1 Magnuson Rep. 34; Hunt, supra note 313, at 75. See also note 324 infra.

321. See, e.g., 117 JAMIA 122 (1941) (digest of second AMA study of group practice in America). 
tice, such as causes for frequent dissolution of groups and the legal snarls of partnership agreements. ${ }^{322}$ Failing to curb the spread of group practice, ${ }^{323}$ organized medicine has tried to keep existing groups within traditional bounds through the ethical code: $: 24$ "The ethical principles actuating and governing a group or clinic are exactly the same as those applicable to the individual."126

\section{Methods of remunerating the physician}

Eight out of ten practicing physicians are self-employed, either as individual entrepreneurs or as members of a partnership firm. ${ }^{326}$ But the number of salaried practitioners has been increasing. ${ }^{327}$ Organized medicine disapproves of this trend and has condemned some types of salaried practice as "unethical," fearing that a doctor's primary loyalty will be to his employer rather than his patient. ${ }^{328}$

For many years certain familiar types of salaried practice have been acceptable to the AMA. Physicians engaged in research, public health work, and teaching do not establish a close relationship with patients, nor could the feefor-service system be readily adapted to suit their circumstances. Military medicine, too, is far removed from the context of private practice. And one physician may hire another on a salary; the employer is subject to the same ethical requirements as the employee, and the patient commands the primary loyalty of both. ${ }^{329}$ Furthermore, such employment is usually for training purposes and temporary, similar to internship or residency.

But organized medicine has not accepted some of the newer developments

322. E.g., Dickinson \& Bradley, Discontinuance of Medical Groups (AMA Bureau of Med. Econ. Research Bull. 90, 1952).

323. The number of physicians engaged in full-time group practice increased from 2093 in 1940 to an estimated 5000 in 1950. 2 MAGNuson REP. 242. However, organizcd medicine's attitude has had considerable effect: "[A] hostile attitude on the part of organized medicine has made it extremely difficult for some groups to recruit or hold new members. Many forms of professional ostracism, including in some cases denial of membership in the county medical society, have acted as powerful deterrents to young physicians wanting to associate themselves with groups." 1 id. 34 .

324. "When any group practice plan was tied in with a questionable insurance scheme or when a patient was restricted to a particular group of doctors by his insurance policy or when any group practice plan restricted a patient in the free choice of a physician, the Association was never hesitant in voicing bitter objection. This was done in the sole interest of better medical care for the patient." Statement of Elmer Henderson, M.D., ex-President of the AMA, 144 JAMA 934 (1950).

325. AMA, Principles of Medical Ethics c. 1, § 3.

326. Weinfeld, Income of Physicians, 1929-49, p. 12 (U.S. Dep't of Commerce, 1951).

327. Ibid. The percentage of salaried practitioners has increased from $13.8 \%$ in 1940 . to $22.3 \%$ in 1949 (figures exclude physicians in armed forces, internes, and residents). Id. at 12 n.13.

328. 147 JAMA 1684-5 (1951). See also AMA, Principles of Medical Etrilcs c. 3 , art. $5, \S 4$.

329. Menns, Doctors, People, and Government 70 (1953); Miller, Rclationship of the Anesthesiologist to the Hospital, 139 JAMA 9, 10 (1949). 
in salaried practice. One of the most widespread has been the hiring of doctors by hospitals. ${ }^{330}$ The practice of radiology, anesthesiology, and pathology is most commonly associated with large institutions. ${ }^{331}$ Each involves large outlay for equipment and deals chiefly with hospitalized patients; none involves the customary strong doctor-patient relationship. And since these specialty departments-staffed by salaried MI.D.'s-often provide profits which cover other operating deficits, ${ }^{332}$ hospital management is reluctant to abandon this system. $^{333}$ But the average net income of the salaried specialist ranges well below that of his self-employed counterpart. The salaried anesthesiologist averages $\$ 10,000$ annually; the independent, $\$ 12,700$. The hired radiologist averages $\$ 12,300$ and the independent, $\$ 18,500.33$ These differentials may have contributed impetus to AMIA disapproval and action against hospital practice.

Medical societies have characterized hospital practice as primarily a moral problem; they fear exploitation and lowering the dignity of the profession, and envision lay-employer control as forcing a lower standard of care for the patient. $^{335}$ The specially-appointed Hess Committee reaffirmed and clarified the AMA's long-standing provision against salaried "purveyal of medical service." 336 The Committee condemned hospital practice and urged component societies to act against institutions and member physicians who work within this disapproved framework. ${ }^{337}$

330. Resolution introduced at AMA Convention, dated June 8,1947 (copy on file in Yale Law Library) ; Snoke, A Step Foriard in Hospital-Physician Rclationships, Hospitals, Oct., 1953 , p. 67.

331. 144 JAMA 394 (1950).

332. Miller, Relationship of the Anesthesiologist to the Hospital, 139 JAMI.1 9, 10 (1949) ; cf. Editorial, It will bcar atatching, Hospitals, Aus., 1949, p. C0.

333. See, e.g., Editorial, stpra note 332; Editorial, A bid for more noncy, Hospitals, Sept., 1949, p. 62-3.

334. Weinfezd, Inconfe of Physiclans 16 (U.S. Dep't of Commercen 1951) (1949 figures). These differentials may be partly attributed to the fact that salaried physicians tend to be younger than independents. Id, at 12. See also Mredical Economies, May, 1953, pp. 118-119.

335. AMA, Relation of Physiclins and Hosfitals (1951); Gree:tezre, Menictine IN CRIsIs 41-2 (Reprinted from Providence Journal and Evening Bulletin, Mrarch, 1951); N.Y. Times, Feb. 22, 1954, p. 21, col. 1; id., Feb. 23, 1954, p. 29, col. 6.

336. 140 JAMA 619 (1949). The Report of the Hess Committee on Hospitals and the Practice of Medicine was drafted in 1947, revised in 1949, 1950, and 1951; for the final version, see AMA, Relation of Physichins axd Hospitals (1951). See also AMA, Principles of Miedical Eteics c. 3, art. 5, $\$ 6$.

337. 137 JAIIA 968 (1948); 140 JAMA 620-1 (1949); Editorial, It zill bcar asalching, Hospitals, August, 1949, p. 60 ("When the Hess Committee members brand as unethical the practice of medicine by a lay corporation, they imply that, under penalty wi losing its approval no hospital may employ a doctor on salary."). See also Editurial, A clear case of misreprescutation, Hospitals, May, 1951, p. 6?.

Despite its earlier unequivocal position, the A.IIA has not carried out threats of enforcement. Its "Guides for Conduct of Physicians in Relationships with Institutions," 147 JAMA 1684 (1951), omitted suggestions for punitive action. Sce also Snolie, stspra note 330 , at 68 . 
But there has been neither extensive nor highly successful activity on the lower levels. The head of anesthesiology of a Boston hospital attempted to change its salary-plus-share-of-profits system, charging that he was being forced to split fees with an institution. Although the hospital admitted making a profit in that department, the local medical society upheld the arrangement. ${ }^{338}$ And similar charges of unethical practices against the Yale Medical School were dropped. The school was retaining the fees paid to its affiliated hospital by patients for services of salaried medical school professors. While state specialty societies have impeded the spread of salaried practice to new hospitals by refusing to recommend, or threatening to expel a member who accepts salaried terms, they have not effected any appreciable change where the practice is already entrenched. ${ }^{340}$

The national organization is unable to initiate action in cases of individual violations of the Hess Report since it is bound by its constitution to wait for charges to proceed through regular channels. ${ }^{341}$ Instead, its officers have tried to work out agreements that can deter salary-paying hospitals. They have requested Blue Cross to refuse to pay hospital bills covering charges for salaried doctors' services. ${ }^{342}$ Conferences have been held with American Hospital Association officials in an effort to work out a compromise arrangement. Both sides have denied an irreconcilable conflict, but after four years of negotiation there is still no agreement. ${ }^{343}$

\section{Methods of payment by the consumer}

In meeting the cost of illness, the consumer is faced with two alternatives. Under the traditional method, he pays in accordance with services actually rendered. ${ }^{344}$ But the need for medical attention is unpredictable and falls un-

338. Boston Herald, Sept. 16, 1951.

339. New Haven Register, May 2, 1951, p. 51, col. 1 (charges made by Executive Secretary of Connecticut State Medical Society; practice defended by Yale Medical School Dean) ; Hospitals, Jan., 1952, p. 65 (Medical Society refers charges to AMA Judicial Council for advice); Snoke, supra note 330, at 68, 162 (charges dismissed).

340. See Snoke, supra note 330, at 68.

341. 138 JAMA 1163 (1948); 137 JAMA 968 (1948).

342. Goldmann, Voluntary Medical Care Insurance 58-9 (1948); 147 JAMA 1684 (1951) ; 137 JÁMA 973 (1948); 42 Iowa State Men. Soc. J. 541 (1952).

343. A Proposed New Statement of Hospital-Physician Relationships, Hospitals, Aug., 1953 , p. 78.

344. 1 Magnuson Rep. 43. The fee-for-service system has been criticized for the following reasons :

1. The doctor usually varies his fees according to his knowledge of the patient's ability to pay, often rendering gratuitous services to the needy. Having the doctor administer an informal "means" test is an unscientific method of apportioning the cost of illness.

2. Physicians tend to locate in areas where they will receive the highest remuncration rather than where they are the most needed.

3. To avoid incurring medical expense, patients do not tend to consult their doctors for periodic checkups or for early diagnosis and treatment. 
evenly throughout the population. ${ }^{345}$ The costs of serious illness, particularly among low-income families, may be financially disastrous. Prepaid health insurance can alleviate such consequences by spreading the risk and expense over a large group. ${ }^{346}$ Under prepayment, the consumer pays in advance to receive medical care and treatment if and when they are needed-not for services actually received. ${ }^{347}$ Consequently he can budget a regular portion of his income to cover such potential medical needs as hospitalization, surgery, or complete medical care.

The AMA endorses the principle of health insurance provided participation is voluntary. ${ }^{348}$ However, organized medicine has not always had this favorable attitude. ${ }^{349}$ In 1932, the report of the Committee on the Costs of MIedical Care, advocating expansion and development of voluntary prepayment plans,

4. Severe illness may be financially disastrous to some families.

See Davis, Problems and Present Methods of Financing Health Serries in 4 Mag:ieso: Rep. 104; Mreans, Doctors, People, ann Governajent 67-70 (1953).

345. Goldmann, Voluntary Medical Care Ixsuraxce 5-6 (1948).

346. Ibid.; Cooley, The Potcutials of Voltutary Health Insturance in 4 Mingtiuso:: REP. 76; 2 id. at 257.

347. Ibid.

348. See, e.g., Cooley, supra note 346 (statement of Secretary of AMA Council on Medical Service before Magnuson Commission); AMA, Volvatranx Prenameneit Mentcal Beneftr Plans (1953).

349. See United States v. Oregon State Medical Society, 95 F. Supp. 103, 113, 118 (D. Ore. 1950), aff'd, 343 U.S. 326 (1952). See, generally, Davis, Asrenica Organizes Miedicine 166-9 (1941) ; Malarberg, 140 Minlion Patients 209-11 (1947).

The AMA's defense of its early record on the prepayment issue is set forth in Dicki:son, A BrIef History of the Attitude of the Asterica: Menichl Assoctutio: Toward Voluntary Health Insurance (AMA Bureau of Aled. Econ. Research Bull. No. 70, 1949). But the American Hospital Association's reaction was one of skepticism:

"Bulletin 70 sets out to prove that the American Micdical Association has never opposed voluntary sickness insurance plans in this country as they exist today.' It quotes many official statements between 1916 and 1938 . It points out that the opposition expressed-and this was sometimes pretty vicious-was aimed at earlier types of plans, not at those currently in operation. This document is not wholly convincing to hospital and Blue Cross leaders whose experience dates back a few years. Nowhere in the selected quotes is there a genuine word of encouragement to voluntary plans, much less a sign of leadership. There are words of caution, of criticism, of fear and warning. There are no words of confidence in the pioneers of voluntary sickness insurance, no words of faith in the principle of prepayment, and not even a forthright statement that some way must be found to malie medical and hospital services more widely available.

"It is a sad fact that through the 1930's and early 1940's, the American Medical Association did not believe in voluntary sickness insurance and did almost everything possible to prevent its development. It is a much happicr fact that during the last few years a great change has been under way. The American Medical Association has supported constructive federal legislation. It has so tempered its official recommendations that state and county medical societies can now support Blue Shield plans. Today it is joining 
was severely condemned. ${ }^{350}$ Experimentation with various methods of prepaid hospitalization, such as Blue Cross, was disparaged and discouraged. ${ }^{\mathbf{g 5 1}}$ The AMA today explains this early opposition on the grounds of inadequate standards of care under existing plans, insufficient payment to physicians, and a fear of governmental domination leading to compulsory participation. . $^{\mathrm{gb2}}$ However, although some early plans did exploit both patient and physician, medical society opposition was directed against almost all such schemes. ${ }^{\text {sts }}$ Not until serious proposals for governmental compulsory health insurance materialized did organized medicine enthusiastically espouse voluntary prepayment. ${ }^{354}$ State societies, encouraged by the AMA, then took the lead in establishing insurance plans. ${ }^{355}$ At the same time, the AMA attempted to shape voluntary plans into an approved pattern. ${ }^{356}$

with other organizations in search of a formula that will make adequate health care universally available-with voluntary prepayment as the basis.

"This is the big news of 1949. The old record is not good, and Bulletin 70 cannot make it look good, but what's the difference? A new bulletin which leaves no doubt that the American Medical Association is now and hereafter determined to find the formula would be a better answer to the association's critics. It would also speed the day when a workable formula is in operation." Editorial, Hospitals, Dec. 1949, p. 60.

350. 99 JAMA 1950, 1952 (1932); 100 JAMA 973 (1933). Sce notes 585-6 infra and accompanying text; MALMBERG, op. cit. supra note 349, at 209; MEANs, op. cit. supra note 344 , at $141-2$.

351. See, e.g., 100 JAMA 973 (1933) (editorial condemning group hospitalization plans as "half-baked experiments in changing the nature of medical practice."); Minor, The Political Make-np of the American Medical Association, Medical Economics, Feb., 1947, p. 80,84 :

" $[I] t$ is difficult to reconcile with actuality the popular fiction ... that the AMA has always fostered experimentation in voluntary prepayment plans. The fact is that the AMA did nothing positive to encourage voluntary health insurance until the formation of Associated Medical Care Plans only a year ago, though in 1938 the House of Delegates had enunciated certain principles approving voluntary hospitalization plans, reversing an action taken five years previously when the plans had been roundly condemned. During the early struggles of the plans, many state and county societies, far from aiding in their development, actually opposed them; and it is reported reliably that AMA officers from time to time expressed consternation at their growing popularity. To Blue Cross executives, among others, the doctrinaire view crediting the AMA with early sponsorship of experimental voluntary prepayment programs emerges as a simple untruth."

352. Dickinson, A Brief History of the Attitude of the American Medical Association Toward Voluntary Health Insurance (AMA Bureau of Med. Econ. Research Bull. No. 70, 1949). See also Henderson, A Fancy Package of Untruths, 144 JAMA 933, 934 (1950).

353. See notes 349,351 supra.

354. See notes 590-1, 650-3 infra and accompanying text.

355. See text at notes 433-8, 444 infra.

356. See, e.g., the AMA standards of acceptance for medical care plans, in AMA, Voluntary Prepayment Medical Benefit Plans 148-50 (1953). 
Prepayment plans may insure against the costs of hospitalization and/or the expense of physicians' services. The most common type of health insurance covers only specified hospital services. ${ }^{357}$ Commercial insurance companies, ${ }^{353}$ as well as the familiar non-profit Blue Cross plans, ${ }^{359}$ offer such policies. State medical societies have approved the Blue Cross plans, ${ }^{300}$ but have objected to the reimbursement to hospitals for services of their salaried doctors. ${ }^{361}$ Other than this objection, and concern over the economic soundness of some insurers, ${ }^{362}$ hospitalization plans have caused no recent controversy within organized medicine.

The recent development of insurance covering the costs of physicians' services, however, has raised more fundamental problems. Two major types of medical care plans have appeared. ${ }^{363}$ Under the cash indcmity system, money benefits are paid to cover specified medical expenses when incurred by the insured. The patient consults his own physician and is reimbursed by the insurance company according to a stipulated schedule. The insurance check may or may not equal the full amount of the doctor's bill. The physician has no contractual relationship with the insurer; he enjoys complete freedom as to the method of rendering his service and determining his fee. Such policies are offered by commercial firms ${ }^{364}$ or by several state medical societies under non-profit Blue Shield incorporation. ${ }^{365}$

In contrast, medical service plans offer their benefits in terms of physicians' services. The patient can consult only a participating physician, from whom he receives any needed care for which he has contracted. The physician is reimbursed for his services by the insurer according to a previous agreement, which may also determine the manner of practice. Lay organizations, ${ }^{300}$ inde-

357. Serbein, Paytng for Menicaz Care in the United States 377 (1953).

358. See generally, Miller, An Exaluation of Mcdical Care Plans Uudcricrilten by Iusurance Companies in 4 MLGavuson REP. 55.

359. Goldacann, Voluntary Memical Care Insunarics 93-113 (1948); SersBEIN, op. cit. suspra note 357, at 341-7; MicNary, An Evaltulion of Bltse Cross Plans in 4 Magnuson Rep. 42.

360. AMTA, Voluntaky Prepayment Meuical Benerit Plusis (1953); New Yont Acadenty of Medicine, Medicine in tae Changing Orner 35 (1947). See also collection of Blue Cross literature, on file in Yale Law Library.

361. See sources cited note $3 \nmid 2$ supra.

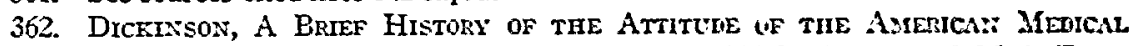
Assoctation Towand Voluntary Health Insurance (AMA Bureau of Med. Econ. Research Bull. No. 70, 1949).

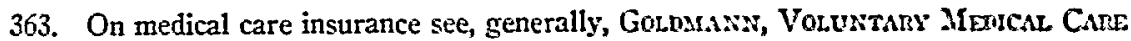

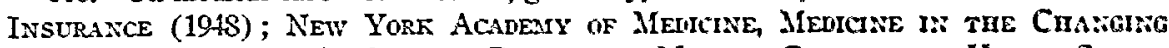
Order 199 et seq. (1947); Serben, Paying for Mfenrcal Care in the Uimten States 75-198, 339-55 (1953).

364. Miller, supra note 358 .

365. AMA, Voluntary Prepayment Mfemcal Benefit Plans 151-3 (1953).

366. AMA, The Growth of Volcnitary Heilta Insunazee 6 (1952) (reporting over 100 independent plans including those sponsored by rural cuoperatives, industry, and union groups). 
pendent groups of physicians, ${ }^{367}$ and a few state medical societies ${ }^{308}$ have sponsored such plans. The majority of medical society plans employ a combination of the two methods, providing for service coverage to lower income groups and cash indemnification for others. ${ }^{369}$ This permits the physician to collect from higher income groups a fee above that granted him by the insurer.

Only under medical service plans does the insurer become a middleman dealing with both physician and patient. $\mathrm{He}$ contracts with consumers to furnish care, and must then obtain this care by securing physicians' services. As contractee with both parties, the insurer is in a strategic position to determine the standard of medical care, services covered, financial arrangements with both parties, consumer membership eligibility, and type of physician participation. For this reason, organized medicine has laid great stress on the sponsorship and control of service plans. ${ }^{370}$

If a medical service plan is operated for profit, the AMA fears exploitation of both patient (through lowering of standards) and physician (by reduction of income)..$^{371}$ This objection cannot pertain to cash indemnity systems-even those operated commercially - because the doctor deals only with the patient and retains control over standards and fee-setting. Service plans controlled by state medical societies are said to provide professional safeguards for the patient and a free choice of physician. ${ }^{372}$ Also the AMA believes that medical society sponsorship shifts the consequences of financial failure. ${ }^{373}$ Subscribers of some early insolvent service plans never received paid-for benefits since funds were insufficient to engage doctors. ${ }^{374}$ But in medical society plans, participating doctors guarantee to provide their services, bearing the risk of the insurer's financial inadequacy..$^{375}$ More important from the standpoint of the profession, medical society plans are open to all member doctors, ${ }^{370}$ and therefore do not affect competition within the membership group. Furthermore, remuneration rates are set on an individual fee-for-service basis ${ }^{377}$ and at a level determined by medical society representatives. ${ }^{\mathbf{3 7 8}}$

367. See, e.g., The Ross-Loos Medical Group in AMA, Voluntary Prepayment Medical Benefit Plans 27 (1953).

368. AMA, Voluntary Prepayment Medical Benefit Plans 151-3 (1953).

369. Ibid.

370. Id. at 9-16; Hayden, An Evaluation of Bhue Shield Plans in 4 MAgnuson Rer. 47 (1953).

371. AMA, Voluntary Prepayarent Medical Benefit Plans 9 (1953).

372. Id. at 148-50; Hayden, supra note 370 , at 53.

373. Dickinson, Methods and Rates of Payment 4 (AMA Bureau of Med. Econ. Research Misc. Publication M-43, 1950).

374. Id. at 3 .

375. Id. at 4.

376. Medical societies and Blue Shield commissions are making strenuous efforts to enlist the participation of physicians. See, e.g., sample solicitation letters from Kansas Blue Cross-Blue Shield and Medical Service Association of Pennsylvania, on file in Yale Law Library. As of December 31, 1951, more than 118,000 doctors had enrolled. FAST Facts about Blue Shield (1952) (Blue Shield Medical Care Plans pamphlet, on file in Yale Law Library).

377. Hayden, supra note 370, at 51 .

378. See, e.g., AMA, Voluntary Prepayment Medical Benefit Plans 21 (1953) 
At one time, organized medicine vigorously attacked prepaid service plans operated by independent physicians; ${ }^{379}$ some of these arrangements now receive qualified approval. ${ }^{380}$ These plans have uniformly combined prepayment with group practice. 381 The choice of physician is thus limited to those practicing as a unit; ${ }^{382}$ subscribers are removed from the doctor's competitive market for patients. The economies of group practice may also enhance the plan's competitive position. ${ }^{333}$ But because the insurer is a group of doctors, themselves subject to ethical precepts, the AMIA does not fear exploitation of this favorable economic position. Rates to subscribers, compensation to participating practitioners, and standards of practice are all under professional control. Medical societies do not encourage such plans, but, unless they violate the professional code by such tactics as advertising, neither do they actively oppose them. 384

The major area of controversy over voluntary health insurance concerns lay-sponsored service plans. ${ }^{385}$ There has been little change in organized medicine's tenacious opposition to provisions found in such plans. However, the AMA has provided a method for approval of these schemes if they conform to certain principles. ${ }^{336}$ The concessions necessary to gain organized medicine's approval are so severe ${ }^{387}$ that, as yet, virtually none have complied. ${ }^{388}$

(Arizona Blue Shield Medical Service: 15 directors of whom 10 must be members of the state medical society) ; id. at 25 (California Physicians' Service: Board of Trustees consisting of 14 physicians and 5 laymen, all appointed by Californiz Mfedical Assuciation). See also id. at 148, Standards of Acceptance for Miedical Care Plans \$2(a): "The plan should provide for the appointment of a committee by the Medieal professicin in the area served by the plan. One of the duties of this committee shall be the dctermination of relative values of medical services and procedures as set forth in the plan's published schedule of benefits. ..."

379. See, e.g., text at notes $415-20$ infra.

380. See testimony of H. Clifford Loos, ML.D., in Hcarings before House Conmilfec on Interstate and Forcign Commerce on I'oluntary Hcalth Insurance, $83 \mathrm{~d}$ Cong., $2 \mathrm{~d}$ Sess. 1464,1468 (1954).

381. Cf. Golduand, op. cit. supra note 363 , at $59,148-50$.

382. Id. at 16.

383. See text at notes $312-16$ supra.

384. Cf. Hearings, supra note 380 , at $1468-9$.

385. See pages $989-96$ infra.

386. See Standards of Acceptance for Medical Care Plans in AMA, Youv:irary Prepayarent Miedical Benefit Plans 148-50 (1953). For a brief accuunt of the historical development of the AMIA's criteria see id. at 9-13.

387. Perhaps the most difficult hurdle to overcome in obtaining medical socicty approval is $\$ 3$ of the Standards, supra note 386: "Free choice of Physician: There should be no regulation which restricts free choice of a qualified doctor of modicine in the locality covered by the plan who is willing to give service under the conditions establishod." State and local medical societies, which have the initial power to evaluste plans, $\$ 1$, have interpreted this free choice provision to exclude prepaid group practice plans which limit coverage to services performed by participating doctors in the group. Bachr, An Eraltation of Independent Prepayment Plans for Medical Care in 4 MInazeson Rer. ol.

Other conditions for acceptance which lay-sponsored plans may find objectionable in- 
The earliest of the lay-sponsored service plans were formed by industrial employers. ${ }^{389}$ Employee groups, often under collective bargaining agreements calling for management support, soon followed. ${ }^{300}$ Schools and universities often employ this device to insure their student bodies. ${ }^{301}$ The number of potential subscribers in each instance is limited to the size of the specified group. On the other hand, groups of consumers outside of industry have formed cooperatives or community-sponsored non-profit corporations to provide prepaid medical services. ${ }^{302}$ These are open to the entire community, subject only to the limitations of available facilities. AMA opposition to this latter type has been much more pronounced than to restricted membership plans.

Regardless of the nature of the sponsoring body, the AMA has laid great stress upon placing control in professional hands. ${ }^{303}$ Such control involves two aspects: over standards of medical care, and over terms of physician participation. Lay sponsoring bodies readily grant the former ${ }^{804}$ But the power to set terms of physician participation means determination of the method of practice and the type and level of doctor remuneration. This, in effect, means control over the table of fees which the plan pays the physician and consequently the rates which the plan must charge the consumer. Furthermore, this latter aspect of professional control must, to meet AMA approval, be vested in a committee representing all the doctors in the community, not just those serving the plan. ${ }^{305}$ So in order to qualify for approval, the laysponsored plan must duplicate the essential elements of medical society plans. Thus it would relinquish the very power which might enable it to outbid individual practitioners and other prepayment systems in the medical market.

clude $\$ 2(a)$, quoted supra note 378 (value of medical services to be set unilaterally by medical profession rather than by sponsoring body and participating physicians); $\$ 10(d)$ (the plan's medical director to be acceptable to county or state medical society); $\&$ (promotional activities subject to approval of organized medicine).

388. Baehr, supra note 387 , at 62 (only one "consumer or community-sponsored" plan approved by a state medical society). As yet, none has the AMA's approval. AMA, Voluntary Prepayment Medical Benefit Plans (1953).

389. Goldmann, Voluntary Medical Care Insurance 148 (1948). For a description of the Endicott-Johnson plan, one of the most famous of the employer-sponsored programs, see Means, Doctors, People, and Government 132-3 (1953) ; Seruein, Paying for Medical Care in the United States 224 (1953).

390. Goldmans, op. cit. supra note 389 , at 148 . See description of several employec plans in SERBEIN, op. cit. supra note 389, c. 18.

391. Dickinson \& Welker, Second Survey of University and College Healti Services: 1949-1950 (AMA Bureau of Med. Econ. Research Bull. No. 88, 1952).

392. Goldmann, op. cit. supra note 389, at 148-9; SERbern, op. cit. supra note 389, at $157-61,164$.

393. See note 387 sipra.

394. E.g., in the Health Insurance Plan of Greater New York, the "entire responsibility for medical matters and the determination of all professional standards are delegated to a medical board and the medical aspects of the programs are supervised by a medical director and his staff." Hearings, supra note 380 , at 1585 . Hansen, Lazes Affccting Group Health Plans, 35 Iowa L. Rev. 209 (1950).

395. Standards of Acceptance for Medical Care Plans $\$ 2(a)$, quoted supra note 378. 
Virtually all disapproved service plans render medical care through group practice. ${ }^{396}$ The combination of lay-sponsored prepayment and group practice has been condemned by the AMIA as "panel medicine." 397 The subscriber must seek his medical services from the limited number of doctors in the group; the AMA views this as a denial of his free choice of physician.093 But from the non-participating doctor's standpoint, there is also a denial of access to potential patients. Another reason for medical saciety hostility to the "panel medicine" combination is its tendency to employ disfavored methods of remunerating the doctor. ${ }^{399}$ Distribution of the group's income on a feefor-service basis is apparently not utilized. ${ }^{200}$ Payment according to the number of patients treated, another possible method, is condemned as tending to lower the quality of care to each individual. ${ }^{401}$ The most common form of physician payment is by salary. 102

From the consumer's standpoint, prepayment group practice schemes offer several advantages. Aside from the economies of group practice, these plans tend to offer more thorough coverage. ${ }^{403}$ Subscribers may contract to receive comprehensive medical care, often with hospitalization as well. ${ }^{102}$ Because it is to the advantage of the plan to minimize illness among members preventive medicine is often stressed. ${ }^{405}$ In contrast, most medical society plans limit benefits, up to a stipulated maximum, to surgery and medical care for hospitalized cases. ${ }^{400}$ To justify the exclusion of such low cost services as oceasional house and office calls, the AMIA contends that these costs are not susceptible to the insurance principle. ${ }^{407}$ The risk falls evenly and widely throughout the population so that the administrative costs of such insurance

396. Goldmann, Potentialities of Group Practice of Mcditine, 10 Co:*.. STste Mren. J. 289, 293 (1946).

397. See, e.g., Master, Impact of Medical Care Plans on the Medical Profession, 150 JAMA 766 (1952).

398. Ibid.

399. Ibid.

400. Hunt \& Goldstern, Medicil Group Prictice in the Liaiten States 19-20, 66-70 (U.S. Pub. Health Service Publication No. 77, 1951) (fee-for-service nut included among prevailing methods of distribution); Goldmann, supra note 396 , at 293 (same).

401. E.g., Master, supra note 397, at 766: "The basic fault of panel medicine is that the physician is paid a per capita fee per year, regardless of how much or how little time he devotes to a patient. Being only human, the panel physician is tempted to run patierits through his office on a mass production basis ... so as to increase his annual incume."

402. HUNT \& GoLDSTEN, op. cit. supra note 400 , at 19.

403. Golomand, op. cit. supra note 389, at 152-3; Baehr, supra nute 387; Hansen, supra note 394 , at 210 .

404. Ibid.

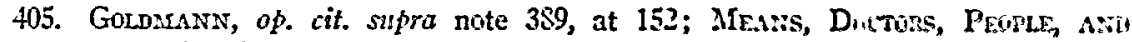
Governament 125, 135 (1953).

406. See description of benefits offered by medical society spuncored Blue Shichl plans in AMA, Voluntary Prepayarent Miemicil. Benefit Plitis 19-119 (1953).

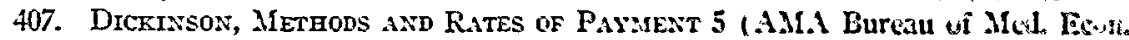
Research Misc. Publication M-13, 1950); Hayden, An Eraltalien of Elte Shisld I'lor's in 4 MAGNuson ReP. $47,49-50$. 
are unjustified. ${ }^{408}$ But this argument does not apply to a vast range of unusual medical exigencies which do not require hospitalization.

The public demand for broader coverage ${ }^{400}$ and competition with lay-sponsored prepayment systems has forced many medical society plans to liberalize their terms. ${ }^{410}$ Some now offer "disaster" riders, covering costs above the standard maximum. ${ }^{411}$ A few have removed income discrimination ${ }^{412}$ while others have expanded benefits to cover complete medical care.413

\section{Methods of controlling disapproved voluntary prepaid health insurance plans}

Even a close analysis of the AMA attitude toward various types of prepaid insurance schemes does not provide absolute predictability of medical society reaction to any given plan. All non-medical society plans contain a diversity of features any of which may be objectionable either alone or in combination with others. Intangible factors such as the climate of political and public opinion, the prestige and influence of the lay-sponsors, and the intensity of professional attitude also govern medical society responses. Yet the two broad considerations of professional integrity and economic interest set outer limits beyond which no privately sponsored plan can venture without incurring vigorous opposition. And these factors provide clues to probable intensity of resistance against any plan containing objectionable features.

Discrimination against participating physicians. For many years attempts to form medical service plans were opposed by organized medicine through direct disciplinary action against participating physicians. The medical practitioner has much to lose when membership in his medical society or the good will of fellow physicians are denied him. It was therefore inevitable that organized medicine would apply its strongest weapon in opposing early attempts to form medical service plans. The AMA's record contains various examples of techniques for disciplining physicians associated with disapproved schemes. ${ }^{414}$

408. Ibid. Dr. Hayden advocates a system of "coinsurance," whereby the insurer and insured would each make partial payment for ambulatory diagnostic services and home and office care. This might prevent any possible excessive or unwarranted utilization of benefits.

409. Baehr, supra note 387 , at 61 .

410. See Group Health Cooperative of Puget Sound v. King County Medical Society, 39 Wash.2d 586, 599, 237 P.2d 737, 745 (1951).

411. See, e.g., California Physicians' Service, Benefits in AMA, Voluntraky PrEpayment Medical Benefit Plans 25 (1953); of. Goldmann, op. cit. silpra note 389, at 84 .

412. See Group Health Cooperative of Puget Sound v. King County Medical Socicty, supra note 410 , at 602,237 P.2d at 747 (absence of salary restriction in cooperative plan led to liberalization of medical society terms). At present, the Washington Physicians Service has no income limits. AMa, Voluntary Prepayment Medical Benefit Plans 100 (1953).

413. AMA, Voluntary Prepayment Medical Benefit Plans (1953).

414. See generally Committee on Research in Medical Economics, Restrictions on Free Enterprise in Medicine (1949) ; 96 Cong. Rec. 13904-18 (1950). 
In 1929 the employees of the Los Angeles Department of Water and Power entered into a doctor-sponsored prepayment service through an agreement with the newly-established Ross-Loos Clinic. ${ }^{115}$ The plan called for comprehensive medical care by the Clinic group's participating physicians as well as hospitalization insurance benefits.110 Subsequently, some of the Clinic's doctors, including a former president of the Los Angeles Cuunty Medical Society, were expelled by that Society. ${ }^{417}$ They were later reinstated on appeal by the AMIA's Judicial Council because of procedural defects in the local society's action. ${ }^{418}$ Since that time the Ross-Loos Clinic has not en-

415. Goldanan, Voltuntary Merical Care Insuraxce 172 (1948). For general discussions of the Ross-Loos Clinic and its development see id. at 172-0; ME1:3, Dostuss, People, and Governuient 130-1 (1953); Testimony of H. Clifford Loos, M.O., in Hearings before Honse Committe on Interstate and Forcign Commerec on I'oluntar! Health Insurance, S3d Cong., 2d Sess. 1451 (1954).

416. Included in the coverage were house and office calls, diagnostic services, medial treatment, surgery of all kinds, and hospitalization. Dependents of enrolled city employees received the same services, though small additional charges such as $\mathbf{5 0}$ cents for an office call and one dollar per house call were made for their coverage. The employee paid two dollars a month. The Nation, Aug. 1, 1936, p. 127.

417. Hearings, supra note 415 , at 1454 . Copies of the expulsion letters received by Drs. Ross and Loos appear in their brief on appeal from the Los Angeles County Medical Association to the Council of the California Mfedical Association, pp. 9, 20, 27 (1934) (copy on file in Yale Law Library).

Expulsion was also directed against a prepayment rural cooperative medical plan established in Elk City, Ollahoma in 1929; the plan contained many features which organized medicine opposed: it owned a hospital staffed by salaricd physicians, had aspects of lay control, offered nearly complete coverage, and solicited membership. The plan's founder, Dr. Michael Shadid, was expelled from his local Beckham County Mfedial Society by the unique device of dissolving the Saciety and reforming thereafter without him. Physicians employed by the hospital repeatedly were refused membership, and both the local and state societies sought revocation of Dr. Shadid's license to practice medicine. Shadid, A Doctor for the Peorle (1939); Plaintiff's Petition, Civil No. 11211, District Court In and For Beckham County, Okla., 1950 (copy on file in Yale Law Library).

In 1950, the cooperative and staff members filed suit for $\$ 300,000$ damages and an injunction against the Beckham County Medical Society, alleging restraint of trade. The action was compromised before trial: the Society agreed to admit members of the cooperative staff; the hospital agreed to open its facilities to Society physicians. Propositions of settlement between Farmers Union Hospital Association and Beclaham County Medical Society (on file in Yale Law Library). This agreement has been termed "clearly a victory for the cooperative." Means, The Best Medicine for the Paticnt, Atlantic Monthly, Dec. 1952, pp. 53, 57.

418. 106 JAMIA 300 (1936); Hearings, supra note 415 , at 1454 .

While expulsion cases like Ross-Loos may be carried on appeal to the AMA Judicial Council, a physician who is denied membership has no such recourse. Sce notes 80.2 and accompanying text. In Chicago, for example, physicians asseciated with the Civic Medical Center, a doctor-controlled prepayment group practice, were denied membership in the Chicago Medical Society. Admission was refused, ostensibly bcesuse the group, fur its first ten months of operation, and a predecessor group, had advertised. But eleven years after discontinuance of this practice none of the staff was admitted to membership despite repeated formal applications and attempts to obtain personal hearings. Both the Illinois State Medical Society and the AMA denied jurisdiction to hear an appal from a non- 
countered further opposition from organized medicine; 410 neither has it accepted opportunities for normal expansion of its facilities or enrollment. ${ }^{420}$

In 1937 HOLC employees in the District of Columbia organized Group Health Association, a non-profit, prepayment medical care and hospitalization program for a limited number of qualified Government employees. Physicians were hired on a full-time salary basis to provide low-cost medical care for members and their families. ${ }^{421}$ The local medical society, however, objected to this lay-sponsored group and employed its coercive powers to destroy this competitive threat to private practitioners. The District Medical Society expelled or otherwise disciplined several of the doctors hired by Group Health ; ${ }^{42 a}$ in some instances mere threats of such action led to resignations from the GHA staff. ${ }^{223}$ Moreover, the Society circulated a "white list" of approved organizations and individuals, from which GHA was excluded, thereby making it impossible for GHA doctors to obtain consultation with fellow physicians. ${ }^{42 .}$

member concerning a local society ruling. Hearings before Committee on Education and Labor on S. 1606, 79th Cong., 2d Sess. 2634-42 (1946).

419. Hearings, supra note 415 , at 1464 .

420. Testimony of Dr. Loos, Hearings, supra note 415, at 1469: "If I had accepted all the groups that applied to us, we would need our city hall to house us. We have put the brakes on. We can't accept too nany. We feel we can't be too big."

421. United States v. American Medical Association, 110 F.2d 703 (D.C. Cir.), cert. denied, 310 U.S. 644 (1940).

422. Id. at 707; Transcript of Record, p. 599, American Medical Association v. United States, 130 F.2d 233 (D.C. Cir. 1942), aff'd, 317 U.S. 519 (1943).

Another early example of expulsion as a disciplinary technique occurred in Logan County, Arkansas, where the entire county society was expelled through the State Society's revocation of its charter. The County Society was allegedly dominated by physicians participating in a disapproved prepayment plan. 27 J. AkK. MED. Soc. 29 (1930). For other examples of expulsion of physicians associated with prepayment plans, see United States v. Oregon State Medical Society, 95 F. Supp. 103, 115 (D. Ore. 1950), aff'd, 343 U.S. 326 (1952); Irwin v. Lorio, 169 La. 1090, 126 So. 669 (1930).

423. United States v. American Medical Association, supra note 421, at 707. The threat of expulsion has usually been sufficient to inhibit the development of prepayment plans. E.g., in Williston, North Dakota, such threats allegedly resulted in an insufficient staff for the Farmers Union Medical Service. Cooperative Henlth Federation of America, Statement to the American Medical Association 8 (1948). Sce also ComMITTEe on Research in Medical Econonics, op. cit. supra note 414, at 10: "More frequently, ... the doctors giv[e] up connection with the prepayment plan, or declin[c] to go ahead with the lay group seeking to organize it. Many plans have thus died a-borning."

424. United States v. American Medical Association, supra note 421, at 706-7. Copies of the "white list" were mailed to District Society members and to all Washington hospitals. An accompanying letter reminded recipients of a rule forbidding association with disapproved organizations. Transcript of Record, American Medical Association v. United States, 130 F.2d 233 (D.C. Cir. 1942), aff'd, 317 U.S. 519 (1943).

See also Committee on Research in Medical Economics, op. cit. supra note 414, at 11-12 (San Diego Medical Society "white listing" by advertisement in telephone directory designating member doctors and statement implying that those not on the list were poorly qualified); Transcript of Record, p. 3927, United States v. Oregon State Medical Society, 343 U.S. 326 (1952). (The Multnomah [Portland, Ore.] County Medical Society discouraging consultation by members with physicians in disapproved plans). 
Furthermore Group Health had no hospital of its own but depended uron the availability and cooperation of local institutions. The AMA and the District Medical Society virtually crippled GH.A by enlisting nearly all the hospitals in the District to deny GHA physicians staff privileges and bed space for their patients. 425 The effective combination of these tacties resulted in the Justice Department's successful criminal prosecution of organized medicine under the Sherman Act. 420

In the State of Washington, Group Health Cooperative of Puget Sound was created in 1946 to give prepaid medical and hospital service to members of several granges, unions, and consumer cooperatives. It hired a staff of twenty doctors to be remunerated by salary and participation with subscriliers in a profit sharing arrangement. ${ }^{427}$ Like the District of Columbia group, it lacked hospital facilities of its own. ${ }^{428}$ Again local medical society intervention caused hospitals throughout the area to refuse GHC doctors staff privileges, and even emergency surgical facilities. ${ }^{429}$ The Society's characterization of

425. In June, 1937, when Group Health appeared to be gaining strength in the District of Columbia, the AMA for the first time in several years conducted an inspection of Washington hospitals to determine which should retain AMA approval. Immediately thereafter five hospitals were sent copies of the MLundt Resolution adonted by the MMA House of Delegates in 1934, limiting hospitals approved for intern training to those staffed by members of component medical societies. Transcript of Recurd, pp. 784-5 American Medical Association v. United States, 130 F.2d 233 (D.C. Cir. 1942).

On Nov. 3, 1937, the District Medical Society decided to explore possible application of the Mundt Resolution as "an apparent means of hindering the successiul operation of Group Health Association, Inc." Id. at 422 . Subsequently a cupy of the following resolution was sent to each local hospital:

"Resolven, That as a matter of educational policy the Mredical Society of the District of Columbia strongly recommends that all hospitals engaged in the teaching and training of residents, interns, and nurses, where possible, follow the recommendations of the American Medical Association regarding the constitution of their entire Medical Staffs, namely, that each appointee be a member of the Medical Society of the District of Columbia .... and a member of the American Miedical Association." Id. at 459.

For results of this policy see $i d$. at $693-8,758$ et seq. (Group Health physician deniod courtesy privileges in a Washington hospital to operate on his hospitalized ratient since he was associated with disapproved plan).

See also note 93 supra.

426. American Medical Association v. United States, 317 U.S. 519 (1943). For a description of the present operation of Group Health Association, see Hcarings, sufpra note 415 , at 1801 et seq.

427. Group Health Cooperative of Puget Sound v. King County Medical Socicty; 39 Wash.2d 586, 603,237 P.2d 737, 747 (1951).

428. Although Group Health owned a 55 bed hospital in Seattle, id. at 604, 237 P.2d at 748, it depended upon outside facilities for its subscribers, id. at 619,237 P.2d at 755 .

429. Id. at $617-25,237 \mathrm{P} .2 \mathrm{~d}$ at $754-\mathrm{S}$. In one instance a $\mathrm{GHC}$ physician was allegedly refused surgical facilities when medical socicty members threatened to remove their patients if he were granted emergency bed space, although there were one hundred bods then available. Brief for Appellants, pp. 23-5.

In Tampa, Florida, a physician furnishing services under contract to a comprehonsive cooperative health plan was denied membership in the Hillsburügh County MIdical So- 
GHC's staff as "unethical" resulted in its withholding or withdrawing membership from several physicians who consequently lost consultation privileges and certification by specialty boards requiring society membership. ${ }^{430}$ In 1949 Group Health doctors sued to enjoin the county medical society under a provision of the Washington State Constitution forbidding combinations or agreements to fix prices or limit production of any "commodity."431 In 1951, the Washington Supreme Court decided for the Cooperative and delivered a forceful condemnation of organized medicine's tactics in attempting to halt the clevelopment of private medical programs in the state. ${ }^{432}$

Sponsorship and promotion of competing plans and restrictive legislation. Despite determined medical society disciplinary action against staff members of disapproved prepayment groups, various forms of medical service plans have continued to grow steadily. Furthermore, the use of discriminatory tactics has been found illegal under both federal and state law. Consequently, organized medicine has softened the use of such techniques, and adopted stbtler, but possibly more effective methods of meeting the threat of prepayment plans.

A concerted effort to set up competing medical society sponsored and controlled plans was the first of these. ${ }^{433}$ Before 1940 three such plans, California Physicians' Service, Michigan Medical Service, and Western New York Medical Plan, were in actual operation. ${ }^{434}$ But their formation focused attention upon two legal questions: whether these plans were subject to state laws governing insurance companies and insurance contracts; and whether these plans constituted the unlawful corporate practice of medicine. ${ }^{436}$ In several

ciety and subsequently barred from the local hospital because he was not a member of that organization. A temporary injunction was issued to permit him to use the hospital. Marcus, Civil Rights and the Anti-Trust Laws, 18 U. of CHI. L. Rev. 171, 196-7 (1951).

See also Hearings, supra note 418, at 2642-3 (Civic Medical Center group denicd access to all but two Chicago hospitals) ; Transcript of Record, pp. 1967-74, United States v. Oregon State Medical Society, 343 U.S. 326 (1952) (non-members already on hospital staff allowed to remain, but no new non-member applicants admitted to staff; society membership also a requisite for position on hospital's governing body).

430. Group Health Cooperative of Puget Sound v. King County Meclical Socicty, 39 Wash.2d 586, 627-32, 237 P.2d 737, 759-62 (1951).

431. Wash. Const. Art. XII, \& 22.

432. Group Health Cooperative of Puget Sound v. King County Medical Society, 39 Wash.2d 586, 237 P.2d 737 (1951). Justice Hamley, for the Washington Supreme Court, declared: "There can be no question but that the purpose of the combination in the instant case is to pre-empt and control all contract practice of medicine in King County. If respondents are successful in this effort, there will be no competition in the contract medicine field. Members of the public will have no opportunity to choose between two or more plans offering this type of service. The result will be a complete monopoly of this product throughout the county." Id. at 640,237 P.2d at 766.

433. These early plans, spurred on by the depression, were originally designed to cxperiment with prepayment for the "borderline income group," one step above the indigent. Holman \& Cooley, Voluntary Health Instrance in the United Statcs, 35 Iows L. Rev. 183,190 (1950).

434. Id. at 191.

435. See generally, Hansen, Laws Affecting Group Health Plans, 35 Iowa L. Rev. 
jurisdictions, these obstacles had proved fatal to non-society plans. ${ }^{430}$ While the elimination of these obstacles to the development of medical society plans provided much of the incentive for organized medicine's promotion of special enabling legislation, ${ }^{437}$ many of the resulting laws were also designed to ensure medical control of all ensuing prepayment schemes.439

To a varying degree most of these statutes restrict the formation and operation of plans to those with medical society approval or control.458 One type of statute requires that a majority of directors be doctors ${ }^{40}$ or they may provide for state medical society approval of directors. ${ }^{241}$ Other statutes bar any prepayment plan from providing medical services unless it includes a majority of the licensed physicians in the area of service.42 The practical effect of stch laws is to prevent lay sponsors or small medical groups from offering prepaid services.

The increased threat of compulsory national health insurance in the 1940 s gave added impetus to organized medicine's development of its own voluntary medical care plans. Although disapproved voluntary plans gained little or no respite from organized medicine, society sponsored plans provided the AMI's positive answer to the argument for governmental action. ${ }^{1 / 3}$ In 1942 the . MMA

209 (1950) ; Comment, Group Health Plans: Some Legal and Economic Aspects, 53 Yale L.J. 162 (1943); Note, The Legal Problems of Group Hcalth, 52 Hasv. L. Rew. 809 (1939).

436. E.g., Cleveland Hospital Service Ass'n v. Ebright, 36 Ohio L. Abs. 600, 45 N.E.2d 157 (Ohio App. 1942), aff'd, 142 Ohio St. 51, 49 N.E.2d 929 (1943) (insurance); Pacific Employers Ins. Co. v. Carpenter, 10 Cal. App.2d 592, 52 P.2d 992 (1935), 25 CALIF. L. REv. 91 (corporate practice of medicine); People v. United Medieal Service, 362 I1l. 442, 200 N.E. 157 (1936) (same). See also Complete Service Iurcau v. San Diego Mredical Soc, 120 Adv. Cal. App. 289, 260 P.2d 1038 (1953) (private plan fails to qualify under statute permitting non-profit lay sponsored systems; held illegal as corporate practice of medicine). Contra: Group Health Ass'n v. Miore, 24 F. Supp. 445 (D.D.C. 1933), aff'd sub nom. Jordan v. Group Health Ass'n, 107 F.2d 239 (D.C. Cir. 1939 ).

437. Hansen, sispra note 435 , at 222. These laws have been the result of state medical society activity. The New Jersey Act, for example, was drafted and lobbied by the society. Conjamtere on Research in Medical Econonics, Resmuctions o: Free Eitremraise IN Medicine 4-S (1949). See also, c.g., 46 I. Kinsas Men. Soc. 119-120 (1945); 35 J. Iowa STATE MIED. Soc. $89-90$ (1945) (state society legislative liaison committees reporting on process of drafting, sponsoring, and securing passage of enabling laws).

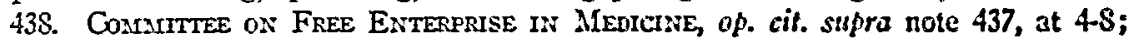
Hansen, supra note 435, at 222-5; Davis, Taken by the Necl, 35 Surier Grapule 403 (1946).

439. Hearings, supra note 415, at 1779-\$5; Hansen, Lau's Affecting Grous Hcalth Plans, 35 Iowa L. Rev. 209 (1950).

410. See, e.g., Fla. Stat. Ann. \$ 641.02(3) (Cum. Supp. 1953); Ga. Cone Az:i. $\S 99-1009$ (Cum. Supp. 1951) ; Iowa Code Avn. \$ 514.4 (1949).

441. See, e.g., 17 Mrich. Stat. Axn. c. 243a, $\$ 24.598$ (1943); N. Huzro. L.w's c. 55, p. 56 (1947) ; N.J. Stat. ANn $\$ 17: 4 \$ A-2$ (Cum. Supp. 1953).

442. See Ky. Rev. Stat. \$ 303.180 (1953); Ohio Gex. Cone Anzi. \$ 669-18(h) (Page, 1946) ; Cone S. CAR. $\$ 37-1106$ (1952); TENs. Cone A:xw. $\$ 418624$ (Williams, Supp. 1952). For other statutes having similar doctor partcipation requirements, sce Hearings, supra note 415 , at $1783-5$.

443. See text at notes $650-3$ infra. 
could point only to eleven medical society sponsored or approved plans; by 1951 the total was 104 such plans. ${ }^{444}$ Medical society plans frequently offer less comprehensive coverage than the independent plans with which they compete. ${ }^{445}$ However, they have exploited their competitive advantages through "medical public education" campaigns and word-of-mouth promotion by family physicians to effect an impressive growth of membership.

The struggle against HIP. Organized medicine is presently bringing the utmost power at its disposal against the Health Insurance Plan of Greater New York. HIP, with almost 400,000 subscribers, is one of the largest group practice, prepayment medical service plans in America. ${ }^{448}$ It was originally promoted by Mayor La Guardia to provide comprehensive health insurance for New York City government employees and their families; ;47 half of the premium is borne by the city and half by the insured. ${ }^{448}$ Since its formation, HIP has opened its enrollment to other employed groups and some individuals.

HIP's organization resembles that of the typical lay-sponsored plan. The plan is headed by a doctor, ${ }^{449}$ but a majority of directors are laymen. ${ }^{460}$ The Board has control over the premium rates and contracts with groups of physicians who, in turn provide medical care to subscribers. Each of the thirty affiliated groups receives a per capita payment based on the number of stibscribers registering with it. ${ }^{451}$ The group divides its receipts among memberdoctors as it wishes; most choose salaried practice, with annual earnings ranging from $\$ 7500$ for starting physicians, to $\$ 18,000$ for senior partners. ${ }^{452}$ The subscriber may select any one of the thirty groups, from which he receives

444. AMA Council on Medical Service, The Growth of Voluntary Healtu InSURANCE 8 (1952).

445. E.g., compare United Medical Service, Inc. (Benefits), AMA, Voluntary Prepayarent Medical Benefit Plans 70-1 (1953), with Health Insurance Plan of Greater New York (Benefits), id. at 121; compare California Physicians' Service (Benefits), id. at 25-6, with Ross-Loos Medical Group (Benefits), id. at 27.

446. Testimony of George Baehr, M.D., in Hearings before Honse Committec on Interstate and Foreign Commerce on Voluntary Health Insurance, $83 \mathrm{~d}$ Cong., $2 \mathrm{~d}$ Sess. 1586 (1954). See generally Hunt \& Goldstein, Medical Group Practice in the UnITED States 25-9 (Pub. Health Serv. Publication No. 77, 1951); MenNs, Doctors, Peorle, and Government 124-8 (1953); Serbein, Paying for Medical Care in the United States 158-61 (1953).

447. N.Y. Times, Jan. 6, 1944, p. 14, cols. 7-8; id., May 1, 1944, p. 1, col. 1.

448. Hearings, supra note 446, at 1585 .

449. The present President and Medical Director of HIP is George Bachr, M.D., former Medical Director, U.S. Public Health Service; Past-President, New York Academy of Medicine; co-editor of Preventive Medicine in Modern Practice (Bachr, Miller, Corwin, eds. 1942).

450. AiMA, Voluntary Prepayment Medical Benefit Plans 121 (1953). Among the original directors of HIP were Winthrop Aldrich; John S. Burke, Director, N.Y. Life Ins. Co.; Henry J. Kaiser; Fiorello LaGuardia; Tracy J. Putnam, M.D., formerly Director of Neurology and Neurosurgery, Neurological Institute of New York; Beardsley Ruml; Gerard Swope. N.Y. Times, Oct. 20, 1944, p. 21, cols. 6-7.

451. Hunt \& Goldstein, op. cit. silpra, note 446, at 28. See also Means, op. cit. supra note 446 , at 127 .

452. Hunt \& GoLDSTEIN, op. cit. supra note 446 , at 28. 
comprehensive medical care.4i3 And the enrollee may choose any doctor within his group as his family physician. ${ }^{454}$ Preventive medicine is particularly stressed ${ }^{453}$ since it is to the advantage of the group to minimize illness among its patients. Premium rates vary according to income and size of family: an individual with an income under $\$ 5000$ pays $\$ 42.72$ per year; a family earning under $\$ 6500$ pays a maximum of $\$ 155.52 .{ }^{457}$ HIP does not cover hospitalization; its subscribers are required to enroll in Blue Cross or an equivalent. ${ }^{45 s}$

From its inception, HIP has steadily grown in size, and the local medical societies' pressure against it has increased proportionately. When Mayor La Guardia suggested the formation of a comprehensive health plan for city employees the medical societies urged utilization of existing services, ${ }^{402}$ and liberalized the benefits of the society-sponsored United Medical Service. ${ }^{460}$ Since then, a controversy between these two competing plans has ensued over the right to advertise. ${ }^{401}$ The ethical code permits society plans to attract subscribers through advertising on the theory that all doctors benefit equally. 402 Although the local medical societies initially tolerated advertising ly HIP, they recently have changed their view and branded the practice as unethical. ${ }^{463}$ An appeal from this ruling has recently been denied at the state level.as

Rather than inviting comparison of their plan with HIP in terms of quality, coverage, and premiums, the local medical societies have disparaged HIP for its alleged denial of free choice of physician. ${ }^{403}$ It is true that HIP sulbscribers can obtain services only from doctors in a participating group. But the independent subscriber can exercise a free choice originally between any available plan, or no plan at all. And if he chooses to join HIP, he has a choice of several groups and of numerous doctors within each group. ${ }^{460}$ Perhaps the doctors' hostility stems from HIP's denying their free access to 400,000 potential patients. ${ }^{467}$

453. Id. at 27; SERBEIN, op. cit. stspra note 446, at 158-9.

454. Ibid.

455. SERBEIN, op. cit. sipra note 446, at 161 ; Hcarings, supra note 446 , at 1590 .

456. AMA, Voluntary Prepayaient Menical Benefit Plaxs 121 (1953).

457. MIEANS, ap. cit. supra note 446 , at 125 .

45s. Hearings, supra note 446 , at 1587.

459. N.Y. Times, July 17, 1946, p. 15, col. 3.

460. Id., Sept. 4, 1945, p. 25, col. 5; id., Sept. 5, 1945, p. 21, cols. 5-6.

461. See, e.g., Master, Impact of Iredical Care Plans on the Medical Profession, 150 JAMIA 766, 767 (1952) ; Baehr, Health Insurance Plan of Greater New Yorl, 150 JAMA 1422 (1952) ; Hearings, supra note 446, at 1603-5; N.Y. Times, Jan. 15, 1954, p. 21, col. \&. See also, articles on medical service plan advertising in Editor \& Publieher, Aug. 8, 1953.

462. See AMA, Princtples of Mlemichl Etmics c. $1, \S \S 4,5$; Hcarings, sugra note 146 , at 1472 .

463. N.Y. Times, Jan. 15, 1954, p. 21, col. S; Hcarings, supra note 416 at 1603-5.

464. N.X. Times, May 13, 1954, p. 1, cols. 3-4.

465. See, c.g., Miaster, supra note 461 ; N.Y. Times, Aug. 6, 1953, p. 23, col. 1.

466. MiEans, op. cit. supra note 46, at 126-7.

467. See Hearings, sitpra note 416, at 1584. But sce statement of Alfred P. Ingegno, 11.D., President of the Kings County Medical Society, in N.Y. Times, Aug. 6, 1953, p. 23, 
Condemning HIP as unethical conveys a threat of possible disciplinary action against affiliated doctors, ${ }^{468}$ and may implant the fear that fellow physicians will view their participation as detrimental to the profession's welfare. ${ }^{460}$ Nevertheless, increasing numbers of doctors have joined HIP affiliated groups. ${ }^{470}$ Consequently the New York medical societies have advocated state legislation designed to destroy the HIP panel practice system. ${ }^{471}$ Under the guise of guaranteeing free choice of physician, the proposed act would have forced prepayment group plans to compensate any physician rendering services to subscribers. ${ }^{472}$ But the 1954 New York Legislature adjourned without passing this measure: now the state medical society is attempting to secure its objective of destroying panel practice groups by "clarifying" its own ethical code. One new interpretation condemns the salaried practice of medicine except in institutions where patients are "public charges"; 473 this ruling would necessitate a fundamental change in the income distribution system of HIP affiliated groups, but would not destroy the plan. Another interpretation, assserting free choice to be denied whenever the patient must choose a physician from a panel or group, ${ }^{474}$ would inevitably outlaw any group practice prepayment system. Whether the New York medical societies will enforce this ruling by disciplinary action against participating physicians is the crucial question..$^{475}$

col. 1: "Naturally, the idea of letting subscribers go to any individual doctor or group of doctors is going to hit the present H.I.P. doctors right in the pocketbook. It will mean surrendering a tight little monopoly."

468. Master, supra note 461 , at 769 (report of medical society resolutions urging expulsion of HIP physicians).

469. Cf. 1 Magnuson Rep. 34.

470. Presently, about 1000 physicians are affiliated with HIP. Hearings, supra note 446, at 1587. Cf. N.Y. Times, Jan. 15, 1954, p. 21, col. 8.

471. In 1952, the medical societies supported the Panken Bill, S. 1082, which would prohibit the operation of plans like HIP. The bill died in committee. Master, supra note 461, at 769. In the 1954 Legislature, a similar measure was introduced in both houscs. N.Y. Times, Feb. 21, 1954, p. 15, col. 5.

472. Ibid.

473. Plumb, State Doctors Vote 2 Steps That Imperil Health Groups, N.Y. Times, May 13, 1954, p. 1, cols. 3-4, p. 32, cols. 4-6.

474. Id., p. 32, col. 6 .

475. A dispute over issues similar to those involved in the HIP controversy is currently in progress on the West Coast. The Kaiser Foundation Health Plan has facilities in major cities in California, Washington, and Oregon. Although originally formed to provide medical services for Kaiser workers, only 22,000 of 416,000 present subseribers are company employees. Hearings, supra note 446, at 1350 . It offers comprehensive health care, preventive medicine, and hospitalization, organized around groups of physicians. See generally Hearings, supra at 1341-1450. Opposition by local medical societies to the Kaiser plan closely parallels that experienced by HIP. See, e.g., 83 BuLt. Los ANcettis CoUnTy MED. Ass'N 510 (1953) (resolution condemning "closed panel procedure" for its denial of free choice of physician, interposition of a "corporate overlord," and interference with professional practices); id. at 501 (editorial, "The Time Has Come," urging doctor opposition to the Kaiser plan). 


\section{ANIA Attitudes toward Health Micasures under Gouermment Auspices}

Governmental activities in the field of public health have steadily increased.tic This expansion has occurred not only through changes in our social and economic philosophies, but also from advances in scientific knowledge. municable disease was once thought to result from environmental defects with a consequent limitation of public health activities to sanitation. But bacteriological knowledge has demonstrated personal communicability, and led to a public concern for the welfare of the individual as well as his environment. ${ }^{2 \pi 3}$ Consequently, public health sunctions have come to include such programs as diagnosis, treatment, and hospitalization. More recently these programs have been broadened so as to cover not only communicable, but degenerntive disease, and maternal and child welfare projects as well.*io

The development of many public health activities has met with hostility from the medical profession. 480 Physicians often resisted such early progranis as smallpox inoculations, diphtheria immunizations, and venereal disease clinics as invasions of the domain of private practice. ${ }^{481}$ Often state health departments, their personnel being influenced by the medical societies, were themselves opposed to expansion into areas of general medical care.452 IThere health officials did institute new programs, they sometimes had to resign from their local medical societies because of opposition to these ventures. ${ }^{43}$ And where medical societies gave approval to diagnosis and treatment by public health agencies, they have favored furnishing care by private practitioners on a free choice, fee-for-service basis, rather than by the less costly salaried physician hired by the state.484

Measures providing public medical care directly to the patient have usually met with the opposition of organized medicine when made available to those able to pay for private services. 185 These programs, it is charged, put the

476. See generally Willard, Fiftcen Years of Public Healh Admististrotion, 10 Pusure ADar. Rev. 99 (1950) ; Roemer, Tronds in Health Legislations: Lacal, State, and National, 23 YaLE J. OF Biol. AND MED. 165 (1950).

477. See, e.g., Wilson, Looking Ahead in Public Health, 26 Afrssissurp Dectur 256, 257 (1949).

47S. Anderson, Public Health $-A$ Mandate from the People, 42 Asr. J. of Ptauc HeALTH 1367, 1369-71 (1952).

479. Ibid.

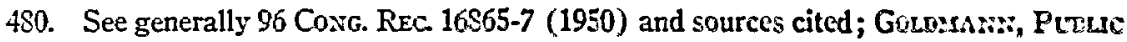
Menical Care (1945); Stern, Miedical Services by Governarent (1946); Andereon, supra note 478 .

4S1. Malatberg, 140 Million Patients 190-1 (1947). But see Henderson, A Foncy Package of Untruths, 14 JAMIA 933 (1950) (denial that AMA record indicates a history of opposition to such programs).

482. Goldxann, op. cit. sipra note 480, at 136; Anderson, supra note 480, at 1371.

483. See Rorty, Asierican Miedicine Mobmizes 2545 (1939).

484. STERN, op. cit. supra note 480 , at 28 ; GoununN, op. cit. supra note 480 , at 99 . See id. at 95-6 for various provisions guaranteeing free choice of physician by the recipient of some types of public medical care.

485. STERN, op. cit. supra note 480 , at 34 (contrasting formal record of AXIA favoring 
state in competition with private practitioners of medicine. As a consequence of opposition from medical societies, the initiative for most public health development has come from outside the medical profession. ${ }^{480}$ Although the American Medical Association today approves a number of public health measures once opposed by medical societies, it would still define the scope of public health more narrowly than most public health officials. A recent resolution would limit health departments to such activities as vital statistics, health education, sanitation, communicable disease, and laboratory and clinical services essential to the control of such diseases. ${ }^{487}$ This concept of public health excludes programs in the field of maternal and child welfare, sight and hearing conservation, care of crippled children, degenerative disease, and mental health.

\section{Governmental level of sponsorship and control}

AMA opposition to governmental health measures, occasionally expressed in terms of general principles, is more often aimed at particular features of administration, sponsorship, or control. Medical society opposition increases in intensity as local administration is bypassed and control is lodged in the Federal Government. Most state medical societies do not uniformly follow AMA pronouncements defining the proper sphere of public health. In many instances state societies formerly in opposition, now cooperate and participate in state administered maternal and child health or degenerative disease programs for the benefit of indigents. ${ }^{488}$ Nevertheless, similar programs under federal sponsorship have encountered AMA opposition. ${ }^{480}$ Organized medicine primarily expresses objection to centralization of control in the Federal Government, not the purposes of the particular program. ${ }^{400}$ Possibly a further explanation for the differential in state and national activity lies in the state society's relatively greater control over health programs within its jurisdiction.

On the state level, medical society control is facilitated by the state health dcpartment's relative freedom from legislative and executive supervision over enforcement, regulation, and development of new programs. ${ }^{401}$ And, under fecleral grant-in-aid programs, funds originating in Washington, but destined for local communities, are routed through the state health office, which thus occupies a strategic position in indirectly determining national policy.492 Joint co-

care at public expense to medically indigent with resistence from local medical organizations to an expansive definition of "indigent").

486. Anderson, supra note 478.

487. Id. at $1372-3$.

488. See, c.g., STERN, op. cit. supra note 480, at 51-2 (report on Old Age Assistance Medical and Dental Program in the State of Washington); Iowa STate Medical Societr, HANDBOOK FOR THE House of DELEGATES 73-4 (1952) (cautious consideration of expanded maternal and child health program).

489. See, c.g., 154 JAMA 510-11 (1954). See also text at notes 520-21 infra.

490. Ibid.

491. Cf. Mustard, Government in Public Health 111-112 (1945).

492. Council of State Governalents, Federal Grants-in-Aid 183 (1949) ("Statc administrative responsibility for public-health work within the state is never questioned. 
ordinating committees of state health department and medical society representatives often draw up regulations and allotments under various specified programs. ${ }^{493}$ Such a relationship may promote the efficient administration of public health measures. But medical society influence goes deeper, pervading health department activity. In many states, the department head is nominated, appointed, or recommended by the state medical society $;^{402}$ in a few states membership in a county medical society is a requirement for departmental appointments. ${ }^{495}$ And, since the statewide cooperation of doctors is essential to the success of any program, health departments must permit the medical societies to participate in the formulation of policy. ${ }^{400}$ This leverage enables organized medicine to protect the interests of the profession against governmental encroachment. ${ }^{497}$

The national organization has been less influential in shaping federal administrative policy. In fact, health leaders of the recent Democratic administrations were openly hostile toward organized medicine. Since 1876 the AMIA has advocated assembling the medical functions of the Federal Government into a single agency of cabinet rank headed by a physician. ${ }^{205}$ The AMIA opposed and contributed to the defeat of two reorganization proposals submitted by President Truman consolidating health services together with welfare and education. ${ }^{499}$ Hostility was grounded upon the fear that Oscar Ewing, advocate of compulsory health insurance and the AMA's arch-enemy, would gain control over medical matters, and that health services would not be independent of other agencies.500 However, after the 1952 election, the same proposal was submitted by President Eisenhower, and on this occasion organized medicine abandoned its former stand. ${ }^{601}$ This reversal followed presi-

Decisions of state health directors are final so long as they stay within the general purpozes of the federal law and the rather broad regulations of the federal supervising agencise. The United States Public Health Service has been extremely careful not to usurp state authority and responsibility.").

493. Barker, The Statc Medical Society and the State Gocenment, 133 JAMA 549 (1947).

494. See note 143 supra.

495. Questionnatre No. 54(d).

496. Datis, Aurerica Organizes Mímictane 115 (1941).

497. Barker, supra note 493, at 549:

"[T]he basis of good relationship with a state government is to have the state medical societies in a position to be consulted abuut appointments to these bourds and agencies. Once this honorable extension of medical society influence has been established, it becomes difficult to put into effect measures which are not compatible with our ideals. Physicians on the boards of such agencies have an unusual oppurtunity to anslyze the effects of proposed measures and oppose them if they are not acceptable to mcdicine, thus adding the weight of government to the side of medicine and not leave the profession to stand alone as a defensive minority."

498. Abel, Medicine in the Changing Sotial Order, Pittsburgh Med. Bull., April 30, 1938, p. 400. See also Fishbein 151, 166, passim.

499. 143 JAMA 560 (1950); Means, Doctors, Peorle, nad Gurer:arens 164 (1953) ; Edwards, Ihe Puts Medicine In the Cabinet, Medical Economies, May 1953, p. 130. 500. Ibid.

501. MEANS, op. cit. supra note 499, at 164; Edwards, supra note 499, at 130-3. 
dential assurances that the new office would not advocate compulsion in the medical field. ${ }^{502}$ Organized medicine probably anticipates a relationship on the national level similar to that enjoyed in the states.

\section{Federal grants-in-aid for health purposes}

Federal grants-in-aid in the health field began with the Chamberlain-Kahn Act of 1918 for control of venereal disease. ${ }^{.03}$ Three years later the SheparclTowner Act was passed providing for grants to the states for maternal and child welfare. ${ }^{504}$ The 1918 act received qualified approval from the medical societies, ${ }^{505}$ but the latter measure was denounced as " $a$ form of bureaucratic interference with the sacred rights of the American home."vos The AMA based its objections not on public activity in this field, but on federal participation in it. ${ }^{507}$ Shortly thereafter, the Association announced its blanket opposition to federal grants-in-aid for medical services. ${ }^{808}$ After a few years both of these grants were allowed to die, ${ }^{, 09}$ and the AMA successfully resisted efforts to revive them until the passage of the Social Security Act. ${ }^{510}$ Under this measure both programs were reactivated, and grants were established for general public health activities as well. ${ }^{111}$ At the present time funds are allocated for a wide variety of public health services, research, and hospital constrttction. ${ }^{512}$

Grants for health services. The American Medical Association now accepts the allotment of federal grants to the states as a "well established principle in our government."'513 In fact, it has itself called for the extension of public health services to areas where needed. ${ }^{514}$ However, the Association emphasizes that public health is primarily a local responsibility, and that there must be a

502. MEANs, op. cit. supra note 499, at 164-6; Edwards, supra note 499, at 136 .

503. 40 STAT. 886 (1918) ( $\$ 1,000,000$ annual appropriation to care for civilians whose treatment was necessary for the protection of those in the armed forces).

504. 42 Stat. 224 (1921). See MacDonald, Federal Aid to the States, 17 NAT. Munictpal Rev. 619, 647-50 (1928).

505. Cf. Irvine, Syphilis and Venereal Disease as a Public Health Problem, 71 JAMA 1029 (1918).

506. 96 Cong. Rec. 13914 (1950) (quoting AMA House of Delegates). Sec also Roemer, Trends in Health Legislation: Local, State and National, 10 YAlE J. OF BroL. AND MED. 165, 168 (1950).

507. 76 JAMA 383 (1921).

508. 76 JAMA 1504 (1921).

509. Council of State Governments, Federai Grants-in-Aid 10 (1949).

510. 49 Stat. 629-35 (1935), as amended 42 U.S.C. § 701 et seq. (Supp. 1952). Title VI of the Act which provided for general grants for public health services is now covcred by 42 U.S.C. $\$ 246$ (1946). See Council of State Governments, Federul Grants-inAID 11 (1949).

511. Id. at 10 .

512. See generally Serbein, Paying for Medical Care in the United States 255.

67 (1953) ; Council of State Governments, Federal Grants-in-Aid 180-92 (1949).

513. 128 JAMA 1101 (1945).

514. 145 JAMA 233 (1951); Hearings before Committee on Interstate and Forcign Commerce on H.R. 5644 and H.R. 5678, 80th Cong., 2d Sess. 77-9 (1948); Hcarings 
showing of actual need by the states. ${ }^{515}$ Similarly, the AMA favors local autonomy in administration.516 Professional advisory committees are favored, ${ }^{517}$ especially if their recommendations are made binding on administrators. 518 Even when these conditions are met the AMA will resist grants for treatment of all but the most contagious diseases unless made contingent on the recipient's inability to pay. ${ }^{519}$

Thus, the AIIA opposed the Pepper Bill of $1945^{520}$ which would have increased the authorized expenditures for maternal and child health, crippled children, and child welfare. The Association protested that the measure contained no means test-grants being available without regard to need-and also that the chief of the Children's Bureau had too much discretionary authority in administering the program. ${ }^{521}$ However, the AMIA gave its approval to the Priest Bill in the last Congress. ${ }^{52}$ This authorized financial assistance to states and subdivisions for local public health units, particularly in national defense areas. Approval followed the adoption of amendments suggested by the Association to guarantee local autonomy and to clarify the types of service that might be rendered. 523

Grants for medical research. When grants-in-aid for medical research were first proposed in the late 1930's the AMIA expressed its disapproval.ost Their objections were said to be based on a fear that federal subsidies would discourage private gifts, ${ }^{525}$ and that such subsidies would not be given without federal control over the manner in which funds were to be used.52s But the AMIA's position changed after grants for such purposes had been passed. The work of the Office of Scientific Research and Development during the war had demonstrated that federal funds could be applied advantageously for promoting research and accelerating the use of medical discoveries. ${ }^{8 T}$ Since that time the ANIA has usually favored measures providing for research grants. ${ }^{\mathrm{t}: 3}$

before Committee on Interstate and Foroign Commerce on S. 132, S. 522, Tille $V$. 1581, and Title $V$ of $S$. 1679, S1st Cong., 1st Sess. 78-82 (1949).

515. See, e.g., $12 S$ JAMA 1101 (1945); Hearisgs ous $S .132$ et al., supra note 514, at \$1-2.

516. Ibid.; 145 JAMIA 322 (1951); Hcarings on H.R. 5644 and H.R. 5678, stopra note 514 at 79 .

517. Id. at 81 .

518. Cf. 128 JAMA 1101 (1945).

519. Cf. Hearings on $S .132$, et al., supra note 514 , at 82 .

520. S. 1318, 79th Cong., 1st Sess. (1945).

521. See, e.g., Editorial, 123 JAMA 1101 (1945).

522. H.R. 274, \&2 Cong., 1st Sess. (1951), approved in 145 JAM1A 322 (1951).

523. 145 JAMA 322 (1951).

524. See, e.g., 109 JAMIA 1280, 1281 (1937) ; N.Y. Times, Nov. 7, 1937, \& IV, p. \&, col. 5 .

525. Abell, Medicine in the Changing Social Order, Pittsburgh Med Eull., April, 1938 , p. 400.

526. 109 JAMA 1280, 1281 (1937).

527. 129 JAMA 699 (1945).

528. As one point in a 12-point program for medical care the ANA recommended "(2) Promotion of medical research through a National Science Foundation with grants 
The creation of a National Science Foundation, as well as a National Cancer Institute and National Heart Institute, has been approved;"520 stuch federal institutes direct important research projects in medicine. ${ }^{630}$

Grants for hospital construction. The AMA has consistently favored federal grants for hospital construction, provided that local need is shown. ${ }^{631}$ Thus the Association approved ${ }^{532}$ the original Hill-Burton Act of 1946 for hospital surveys, construction, renovation, and improvement. ${ }^{533}$ Hill-Burton funds are applied only to the physical plant of hospitals, not for medical services. Also this program has operated primarily to assist hospitals of small capacity in rural areas where need is greatest. And federal funds, as in most grant programs, are channelized through state health departments.

Grants for medical education. The increased cost of medical education has led to recent proposals for federal aid. ${ }^{634}$ No measure submitted thus far has received organized medicine's approval-and none has been enactec-despite AMA denial that it opposes federal grants to medical schools. ${ }^{635}$ At first, such grants were incorporated into the omnibus National Health Act along with

to private institutions which have facilities and personnel sufficient to carry on qualified research." 139 JAMA 529 (1949).

529. FISHBEIN 488 (National Science Foundation); Hearings before Subcommitlec of the Committee on Labor and Public Welfare, on S. 720 and S. 2215, 80th Cong, 2d Sess. 115 (1948) (National Heart Institute).

530. Forty-two percent of the $\$ 180,000,000$ devoted to medical research each year in the United States comes from the Federal Government. 2 MAGnuson REP. 234. Federal activities consist of direct research in federal laboratories and facilities, and grants to medical schools, hospitals, universities, and clinics. Additional funds are provided for fellowships and construction. See 1 Magnuson Rep. 39-42; 2 id. at 234-9; Sexpetn, PaYing for Medical Care in the United States 268-74 (1953).

531. See, e.g., 114 JAMA 490 (1940) (approval of Wagner Bill, S. 3230, 76th Cong., $2 \mathrm{~d}$.Sess. (1940), providing grants for hospital construction).

532. Hearings before Subcommittee of the Committee on Interstate and Forcign Commerce on S. 191, 79th Cong., 2d Sess. 100 (1946) (testimony favoring Hill-Burton Act).

533. 60 Stat. 1041 (1946), as amended, 42 U.S.C. $\$ 291$ (Supp. 1952). Analyses of the Act and its operation are found in 2 MAgnuson Rep. 196-9; SERBein, PAYing For Medical Care in the United States $275-7$ (1953); Council of State Governments, Federal Grants-In-Aid 185-9 (1949) ; Hoge, Progress Report on Hospital Survey and Construction Act, 39 Arr. J. of Public Health 889 (1949).

As of September, 1952, a total of 1877 projects providing 90,645 beds had been approved under the Hill-Burton program. The total cost of these facilitics was estimated at $\$ 1,457,000,000$, the Federal Government contributing $\$ 517,000,000$ or 36 percent. 4 MAGNUSON REP. 278.

534. Financial problems facing the nation's medical schools are discussed in 1 MAGNuson Rep. 11-15; 2 id. at 130-5. Proposals for federal aid are found in $1 \mathrm{i}$. at 15 . See also Means, Doctors, People, and Government 85-8 (1953); Greennberg, Medicine in CRISIs (reprinted from Providence Journal and Evening Bulletin, March, 1951); Maisel, Our Alarming Doctor Shortage, Collier's, Dec. 16, 1950, p. 18.

535. The AMA has stated that it "advocates financial aid to medical education with funds that will preserve the freedom of the medical schools from political control and regulation," 141 JAMA 1155 (1949), but it has consistently opposed all aid proposals on the ground that they do not insure free and local operation of the schools. See, c.g., 145 JAMA 232, 233 (1951). 
controversial compulsory health insurance proposals. ${ }^{335}$ In the hope of expediting bipartisan action on the aid to education portion, Senators Murray, Pepper, Taft, and Donnell sponsored a separate bill in 1949.037 This measure and its House counterpart, ${ }^{\text {b3s }}$ after committee consultation with AMA representatives, ${ }^{539}$ were amended to limit federal participation in the budget of any medical school to $40 \%$, and to give a professional advisory council, responsible to Congress, the duty of making recommendations to the U.S. Surgeon General before he could promulgate regulations under the program. any federal "direction, supervision or control with regard to personnel, curriculum or instruction" was expressly forbidden."11 After Senate passage of this measure by unanimous vote, ${ }^{, 52}$ the American Mredical Association announced its opposition to the measure. ${ }^{\text {T33 }}$ In accordance with the Association's recommendations, ${ }^{544}$ the House then placed a $30 \%$ limit on federal participation but AMA still opposed the bill, and it died in Committee. ${ }^{\text {bit }}$ Similar measures introduced since that time have met a like fate. ${ }^{540}$ The AMIA has announced that it would support single installment federal grants for the construction and renovation of medical school plant similar in terms to the Hill-Burton grants for hospital construction. .HT $^{4}$

The AMIA bases its opposition to medical education subsidies on a fear that federal domination over the schools will result, and that educational standards will deteriorate. ${ }^{548}$ Critics of this argument, particularly the deans of the medical schools, who have been overwhelmingly in favor of federal aid, ws point out that the schools are already receiving large grants for research and these have resulted in no federal control. ${ }^{550}$ Some observers attribute organ-

536. S. 1606, 79th Cong., 1st Sess. (1945) ; S. 1320, S0th Cong., 1st Sess. (1947).

537. S. 1453, S1st Cong., Ist Sess. (1949). Senators Humphrey, Neely, Thomas, Hill, Douglas, Graham, Aiken, Smith (N.J.), and Morse also joined as sponsors. Grants of $\$ 500$ per student were to be made to help meet current operating deficits, with additional sums available to schools increasing their enrollment. An additional $\$ 5,000,000$ was allotted for construction and equipment of physical facilities.

538. H.R. 5940, 81st Cong., 1st Sess. (1949).

539. Maisel, supra note 534 , at 19,82 .

540. Id. at 82 .

541. Ibid.

542. Ibid.

543. See 141 JAMIA 1155 (1949).

544. See 142 JAMA 182 (1950).

545. See N.Y. Times, Aug. 17, 1950, p. 11, col. 2 ; id., Aug. 20, 1950, p. 11, col. 1.

546. E.g., S. 337, 82d Cong. 1st Sess. (1951). See N.Y. Times, Oct. 5, 1951, 1. 16, col. 3. The bill provided a $\$ 500$ grant-in-aid for exch medieal student currently enrolled, and an additional $\$ 500$ for each student enrolled in excess of past enrollment.

547. 149 JAMIA 1654 (1952).

548. See, e.g., 146 JAMA 1238 (1951).

549. S. 1453 and H.R. 5940 were endorsed by $75 \%$ of the medical school deans. N.Y. Times, Aug. 20, 1950, p. 11, col. 1.

550. Dr. George Packer Berry, Dean of Harvard Medical School, stated that, "We now spend more than a million dollars a year in federal funds at Harvard Medieal Seluid, and it has come to us without any strings attached or any effort to côntrol us. I sce 
ized medicine's attitude to a fear that medical education subsidies would constitute a further acknowledgment of federal responsibility in providing medical care and thus pave the way for "socialized medicine." 551 And perhaps the AMA fears loss of some of its present power to influence the size of medical school enrollment.

Furthermore the AMA contends that adequate support for medical education may be had from voluntary sources, that the availability of such sources has not been full explored, and that federal subsidies would discourage the development of private support. ${ }^{552}$ The AMA has supported the efforts of the National Fund for Medical Education in obtaining contributions from private and corporate sources. .53 And in 1951 the Association announced the formation of its own American Medical Education Foundation to aid the National Fund. ${ }^{554}$ The Foundation has received large amounts from the AMA and its constituent and component societies, as well as individual physicians. ${ }^{\text {tot }}$ Critics charge that the fund is a mere diversionary action to shift attention from the need for federal aid, and is sure to be inadequate to meet the annual deficits of the medical schools. ${ }^{556}$ Indeed, while estimates of medical school needs above present income range from $\$ 10,000,000^{557}$ to $\$ 40,000,000558$ annually, the Fund contributed less than $\$ 2,000,000$ in 1953.550 However, the AMA claims that private contributions can provide a solution to the financial crisis facing medical education. ${ }^{560}$

\section{Federal health services}

United States Public Health Service. Many federal health measures are carried out through grants-in-aid whereby the Public Health Service is responsible only for overall administration, with most discretionary authority being delegated to the states. ${ }^{501}$ But the Service itself directly administers

no ground for apprehension if the schools maintain a proper balance between their own funds and federal grants." Greenberg, op. cit. supra note 534, at 28.

551. Ibid.

552. Ibid.; cf. 145 JAMA 160 (1951).

553. The National Fund was established in 1949 through the efforts of the AMA, the Association of American Medical Colleges, the National Association of Manufacturers, and others.

554. 145 JAMA 160 (1951).

555. See 152 JAMA 1044 (1953).

556. See, e.g., 96 Cong. Rec. 16861 (1950) (address by Rep. Andrew Biemiller).

557. National Fund for Medical Education, Report to Contrinutors, 1953 (1954).

558. 2 Magnuson Rep. 131; N.Y. Times, Feb. 18, 1951, p. 53, col. 1 (report of stitdy for the U.S. Surgeon General).

559. During 1953 the Fund received contributions totaling $\$ 2,400,833$, including $\$ 1,044,602$ from the AMA's American Medical Education Foundation. Grants to the medical schools were $\$ 1,944,152$. National Fund for Medical Education, Repont to Contributors, 1953 (1954).

560. 149 JAMA 44 (1952); 149 JAMA 1319 (1952).

561. Council of State Governments, Federal Grants-in-Aid 180 (1949). 
numerous programs. Many of these are "old line" public health functions such as vital statistics, pollution control, and international quarantine. tion, the Service now operates direct programs for the treatment of narcotic addicts, employees of certain Governmental services, and seamen, and for the provision of a wide variety of other health services. ${ }^{503}$ The development of such projects has not met with the opposition from organized medicine that have some of the grant proposals. Most Public Health Service programs are of a limited nature, not competitive with private practitioners.

IIilitary and veterans' medicine. During World War II, Congress instituted an Emergency Maternal and Infant Care program to provide medical care for servicemen's wives and children. ${ }^{\text {vat }}$ Although the AMA endorsed the program it opposed direct EMIC cash payments to participating physicians, ${ }^{365}$ and some medical societies refused to cooperate unless payments were made to servicemen's wives. ${ }^{566}$ Today, the national organization is resisting efforts to revive any form of EMIC. 567 Servicemen's dependents can now receive medical care in military hospitals on the post provided there is sufficient eapacity. Families not living within range of the post hospital must arrange and pay for treatment on their own. ${ }^{569}$ A series of recent bills ${ }^{5 \pi 0}$ introduced to provide off-the-post care has been unsuccessful and the AMA no longer fears the likelihood of a broader EMIC program. ${ }^{\mathrm{bt}}$

Ever since the establishment of governmental medical services for World War I veterans ${ }^{572}$ the AMIA has consistently led efforts to block the extension

562. Feperal Securtity Agency, Guine to Helita Organization in tae U:itad States 18-28 (1953).

563. Ibid. For a description of the direct activities carried on by the U.S. Public Health Service see Serbein, Paying for Mrencis Care ni the United States 246 -52 (1953); Steras, Mifoical Seruices by Governarent 145-64 (1945).

564. 57 Stat. 28 (1943). The EMIC program provided maternity eare to the wives of men serving in the four lowest grades of the military forecs, and medical care for their children under one year of age. Before its termination in 1949 EMIIC provided services to almost one and a half million mothers and infants at a total cost of \$127 million. Roberts, Public Medical Care: The Ozer-all Picture, 273 Awruss 71 (1951). Cf. AMA, Medrcal Serutices to Depennents of Seruicenten (1952).

565. Ajia, Survey of Federal Mieticil Sermees 79 (1952).

566. Stern, Miedical Services by Governarent $131-5$ (1946).

567. S. 1245 and S. 2337, 82d Cong., 2d Sess. (1952), vould have reestablished EMIC. In committee hearings the AMA opposed those bills on the ground that there was "no demonstrated need" for such a program. 145 JAMA 1037 (1952). The AMA has viewed more recent attempts to recreate the program as an "opening wedge on socialization" of medicine. N.Y. Times, Nov. 1S, 1953, p. 14, col. 2.

568. 23 Stat. 112 (18S4), 10 U.S.C. \$ 96 (1946) (army and air force); 57 Star. 80 (1943), 24 U.S.C. $\$ 32$ (1946) (navy). Administrative regulations governing dependent care are found in AMA, SURvey of Feneril Memcil Sentzess 38-10 (1952).

569. N.Y. Times, March 16, 1952, p. 34, col. 4.

570. See, e.g., S. 1495, H.R. 4642, 83d Cong., 1st Sess. (1953).

571. 153 JAMIA 844 (1953).

572. DIedical benefits to veterans with respect to service-cunnectcd conditions were provided in an amendment to the War Risk Insurance Act. See 40 Sr.1T. 466 (1917). In the World War Veterans' Act of 1924 Congress extended bonefits withut regard to the 
of Veterans Administration care to include non-service connected disabilities.673 Under present law VA hospitals are permitted to care for such cases to the limit of available beds and if the recipient cannot defray the expense of private treatment. ${ }^{574}$

The VA's intensive hospital construction program is constantly increasing available facilities. ${ }^{575}$ During its campaign against compulsory health insurance, the AMA, not wishing to alienate the American Legion, soft-pedalled its opposition to the growth of VA medicine. ${ }^{576}$ But more recently, organized medicine has opposed further construction of VA hospitals ${ }^{677}$ and urged that treatment even of service-incurred disabilities be kept within the limits of existing facilities. ${ }^{578}$ The AMA is against any federal care of non-service connected disabilities; it advocates state or local care for veterans unable to pay for private care. ${ }^{579}$ In lieu of this, however, it has urged a more exacting means test to disqualify financially able veterans. ${ }^{580}$ Of 24 bills concerning veterans' medicine pending in the 1954 Congress, the AMA has announced its active approval of only one-a bill to investigate the VA. ${ }^{\text {s81 }}$

nature or origin of the disabilities but giving preference to needy veterans. 43 STAT. 620 (1924).

573. Commenting on the Veterans' Act of 1924 the Board of Trustees reported: "The situation may almost be stigmatized as communistic medicine in its most militant form, endeavoring to edge its way into American life under the cloak of patriotism." AMA, Survey of Federal Medical Services 75 (1952).

574. 48 STAT. 9 (1933), as amended, 38 U.S.C. \& 706 (1946). While veterans with non-service-connected disabilities can receive hospital treatment they cannot receive outpatient or preventive medical care that might avert the need for hospitalization. For a brief description of the VA medical program, see Serbetn, PAying for MEdical Care in THE UNITEd STATES, 238-44 (1953).

575. Sec Herrick, The Problem of Medical Care, N.Y. Herald Tribune, Feb. 2, 1952, p. 8, cols. 5-7.

576. Dr. R. J. Wilkinson, President of the Southern Medical Association stated that he was "shocked and amazed" at the AMA's "hands-off attitude" toward the VA hospital program. Dr. Wilkinson said "I have been repeatedly told by high-ranking officers of this great AMA organization that we must adopt a policy of 'status-quo' because of the American Legion's attitude in helping defeat the Wagner-Murray-Dingle bills." Bangor (Maine) Commercial, Nov. 10, 1952. See also Croatman, That Veterans' Lobby, Medical Economics, Nov., 1953, p. 128.

577. 152 JAMA 1718 (1953).

578. N.Y. Times, June 4, 1953, p. 36, col. 2. The AMA believes that existing facilities can serve all future needs of the veterans with service-connected disabilities and denics any intent to curtail such treatment. See 152 JAMA 1718 (1953); 152 JAMA 1343 (1953).

579. Ibid. Arthur J. Connell, National Commander of the American Legion has recently attacked the AMA for its stand on VA medicine calling the Association a "most powerful and monopolistic medical guild." N.Y. Times, Jan. 29, 1954, p. 17, col. 3.

580. N.Y. Times, July 11,1953 , p. 13 , col. 8 . The VA recentiy announced that veterans seeking treatment for non-service-connected disabilities would be asked to provide information concerning their financial status. VA Press Release, dated Nov. 5, 1953 (copy on file in Yale Law Library). Previously the applicant merely had to "affirm" his inability to pay for private care.

581. 154 JAMA 510-11 (1954). 


\section{Compulsory health insurance}

Federal health insurance proposals were a culmination of two lines of development: the recognition of the insurance principle as adaptable to meeting medical costs, and the increasing scope of governmental interest and participation in the provision of medical care. The public and many individual doctors have accepted both patterns, often from direct contact with voluntary prepayment schemes on the one hand, and with state and federal health services for fractional segments of the population on the other. Organized medicine has generally resisted each of these developments. However, these encounters with innovation seem but skirmishes in comparison to the bitter struggle which followed the merging of the two lines into compulsory health insurance.

Development of a national health program. While prepaid governmental medical care has become a major issue in this country only recently, European experiences stimulated some mild interest here nearly forty years ago. The ANIA at this time received reports from abroad with equanimity and began to consider the possibility of adopting such programs in the United States. $\overline{83}$ But by 1920 its position was clearly one of opposition to government controlled or regulated medical service. ${ }^{.83}$ In 1932, the majority report of the Committee on the Costs of Medical Care ${ }^{\text {sSo }}$ indicated tentative approval of tax-supported health insurance, and received wide attention in medical circles.556 It was in 1935 that the New Deal became interested in the passage of a health insurance law as part of the social security program. 1938 the issue of compulsory health insurance had assumed more threatening proportions for the AMA. The President's Technical Committee on Medical Care, appointed to study the 1935 Social Security Act, recommended a pro-

582. Fishbein 281, 286, 289, 292, 296; Davis, Axrerica Organizes Mieniciric 166-7 (1941).

583. FISHBEIN 296-7.

584. Id. at 321 .

585. The Committee on the Costs of Medical Care was financed by grants from eight private foundations. It was headed by Dr. Ray Lyman Wilbur, a former AMIA President, Secretary of the Interior under President Herbert Hoover, and President of Stanford University.

586. Means, Doctors, People, and Governarent 141-3 (1953); Dums, Azmenca Organizes MiEdCine 177 (1941).

587. FisHBEIN 410-17. In 1934 President Roosevelt had appointed a Committee on Economic Security; Secretary of Labor Perkins formed a Medical Advisory subeommittee which recommended "a nationwide preventive medicine and public health program and application of the principles of iisurance." The President's Mlessage to Congress in January, 1935, stated: "I am not at this time recommending the adoption of so-called 'health insurance,' although groups representing the medical profession are cooperating with the federal government in the further study of the subject and definite prostess is being made." Quoted id. at 415-16.

The California Medical Association flirted briefly in 1935, with statevide compulsory health insurance, having adopted a resolution approving it in principle. Id. at 417. 
gram of medical care and sickness insurance. 588 In an Address to the Congress, President Roosevelt asserted that medical care for the people was a matter of public concern. .80

At this point the AMA abandoned its resistance to the insurance principal for meeting the costs of medical care. ${ }^{500}$ The issue became whether medical society or governmental auspices for health insurance provided the best solution. Organized medicine opposed anything which might divest it of any part of its control over medical services. ${ }^{501}$

The first serious legislative proposal for a national health program was introduced by Senator Robert Wagner of New York in 1939.502 It followed closely the program of the President's Technical Committee and provided for grants-in-aid to the states to enable them to develop plans of their own choosing ${ }^{503}$ - subject to basic standards set by the Federal Government. Despite a favorable interim report from the subcommittee which studied the bill, ${ }^{595}$ the AMA's own study committee submitted twenty-two distinct arguments against it ${ }^{506}$ and no further action was taken. The next significant

588. Anderson, Compnlsory Medical Care Insirance, 1910-1950, 273 ANNals 106, 11.1 (1951).

589. Davis, America Organizes Medicine 247 (1941).

590. The AMA House of Delegates in 1938 approved a reference committee report containing the following statement of principles:

"Your committee repeats its conviction that voluntary indemnity insurance may assist many income groups to finance their sickness costs without subsidy. Further development of group hospitalization and establishment of insurance plans on the indemnity principle to cover the cost of illness will assist in the solution of these problems."

Reference Committee on Consideration of the National Henltir Program, Report to the House of Delegates, Proceedings of the House of Delegates, Siectal. Session 54 (1938).

591. To meet the proposals for compulsory health insurance, the AMA applicd its 1934 set of criteria for voluntary plans, AMA, Voluntary Prepayment Medical Cake PLANs 10 (1953), and attacked "socialized medicine" in terms of control of management and medical standards, freedom of choice, doctor-patient relationship, "means test," and compulsion. See Dickinson, A Brief History of the Attitude of the Amekican Medical Association Toward Voluntary Health Insurance 20-21 (AMA Burcau of Med. Econ. Research Bull. No. 70, 1949).

592. S. 1620, 76th Cong., 1st Sess. (1939), reprinted in 84 Cong. Rec. 1976 (1939).

Previous bills had been introduced by Senator Capper of Kansas in 1935 and 1937; although similar to the Wagner proposal, they received little attention. Anderson, Compulsory Medical Care Insurance, 1910-1950, 273 Annals 106, 111 (1951). See also S.J. Res. 188, 75th Cong., 1st Sess. (1937) (proposal by Senator J. Hamilton Lewis of Illinois making all practicing physicians "civil officers of the United States" for the purpose of caring for "the impoverished"; compensation chargeable to the Social Security Board).

593. The bill envisioned a $\$ 35,000,000$ annual grant-in-aid program. 84 CoNG. Rec. 1980 (1.939).

594. Ibid. To be approved, a plan was required to give state-wide coverage, with substantial financial participation and close supervision by the state. For failure to maintain these standards the Social Security Board would be empowered to withdraw approval.

595. 93 Cong. Rec. 5517 (1947).

596. FISHBEIN 449. 
health measure was the first Wagner-Murray-Dingell Bill, of 1943.507 This provided for a federal system of medical and hospital benefits, with medical care payments from a fund composed of equal payroll contributions from employer and employee. ${ }^{598}$ Senator Wagner denied that the bill would sacialize the medical profession, pointing to provisions maintaining the doctor's freedom to remain outside the program, to choose his own patients, and to determine by what method he should be paid. ${ }^{693}$ However, the bill provided that each patient could select the doctor of his choice only from participating physicians. ${ }^{600}$ MIoreover, the Surgeon General was given extensive powers to set fee schedules and limit the size of the doctor's panel of patients. ${ }^{01}$ These proposals brought forth violent reaction from organized medicine ${ }^{62}$ and the bill died in committee. ${ }^{603} \mathrm{~A}$ similar Wagner-Mrurray-Dingell proposal ${ }^{603}$ followed President Truman's special message to Congress in November, 1945, ${ }^{\cos }$ but even with outspoken administration support the bill was no more successful than its predecessor. ${ }^{008}$

In 1946 and 1947, however, Senator Robert A. Taft sponsored an alternative measure to the administration's program. The Taft Bill, ${ }^{\mathrm{csi}}$ instead of health insurance, proposed locally-administered federal subsidies to the states to assist "those families and individuals in the state having insufficient income to pay the whole cost of" health services. The AMIA did not react unfavorably, but fearing the possibility of lay administration at the local level, it was unenthusiastic. $^{\text {.08 }}$ Also in 1947 the newly-elected Republican Congress considered a significantly modified Wagner-MIurray-Dingell Bill. ${ }^{\text {cos }}$ Conforming to criticism of the earlier bills, the sponsors assigned the duties formerly designated for the Surgeon General to a five-man board in the Federal

597. S. 1161, 78th Cong., 1st Sess. (1943), summarized in 89 Cosc. Rre. 5258 (1943).

598. 89 CoNg. Rec. 5258 it seq. (1943).

599. $89 \mathrm{id}$. at $\mathbf{5 2 6 0 .}$

600. 89 id. at 5261 .

601. Ibid.

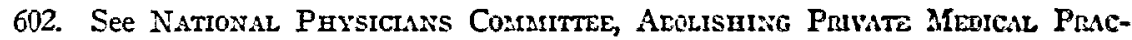
tice, of $\$ 3,0 \$ \$, 000,000.00$ of Political Mínicine Yearly in tue United Sintes 3 (1943) : "The processes proposed and the mechanisms indicatcd are designed to act as the catalyst in transforming a rapidly expanding Federal bureaucracy into an all poweríul totalitarian state control. Human rights as opposed to slavery is the issue."

603. 93 CoNG. Rec. 5517 (1947).

604. S. 1606, 79th Cong., 1st Sess. (1945), summarized in 91 Covg. Res 10739 (1945).

605. H.R. Doc. No. 380, 79th Cong., 1st Sess. (1945).

606. Anderson, supra note 592, at 111.

At its annual meeting of 1945 , the AAIA passed a strungly-worded resolution cundemning the bill, FISHBEIN 4\&6, and spokesmen for organized medicine publicizcd the AMIA's stand. N.Y. Times, Dec. 10, 1945, p. 23, col. 5. See Hearings before Conmaitlec on Education and Labor on S. 1606, 79th Cong., 2d Sess. (1946).

607. S. 545, S0th Cong., 1st Sess. (1947), criticized by Senator Miuray in 93 Co:ic. REC. 5520-1 (1947).

608. N.Y. Times, July 6,1946, p. 17 , col. 4 .

609. S. 1320, S0th Cong., 1st Sess. (1947), summarized in 93 Conc. Rec. 5517 ct seq. (1947). 
Security Agency, and control of the proposed program was further decentralized: but more services were offered, and more groups were covered.010

The last major administration health insurance bill was inspired by the Ewing Report of 1948.611 This Report endorsed a national health program and was instrumental in the identification of its author with compulsory health insurance. Ewing's proposals received the full backing of President Truman in the 1948 presidential campaign. ${ }^{612}$ AMA anxiety was heightened by the election returns and the prompt introduction in January, 1949, of a bill similar to the 1947 Wagner-Murray-Dingell proposal. ${ }^{613}$

AMA tactics of opposition. Organized medicine's earlier attempts to block the passage of compulsory health insurance displayed an essentially ad hoc approach. The earliest proposals for national health insurance required little more than vocal opposition by medical spokesmen. With the introduction of Senator Wagner's 1939 Bill, however, the AMA and many state societies intensified their campaign against government medicine. ${ }^{614}$ The AMA's cause was almost entirely taken up by the newly formed National Physicians Committee for the Extension of Medical Service, which served as the propaganda arm of organized medicine. ${ }^{615}$ Although the AMA denied any official connection with this organization, ${ }^{616}$ the NPC was headed by AMA members ${ }^{017}$ and supported by its fund-raising machinery. ${ }^{618}$ For nearly ten years, the AMA itself confined its official opposition to state insurance to public ad-

610. 93 id. at $5520-2$.

611. Ewing, The Nation's Health, A Ten Year Progran: A Report to the President (Fed. Security Agency 1948).

612. President Truman declared that he was "compelled to advocate national health insurance" and that he saw "no other possible way to bring medical service to fully half the American people." 138 JAMA 297 (1948).

613. S. 1679, 81st Cong., 1st Sess. (1949). For a discussion of this and other health measures introduced in 1949, see Comment, Essentials of an Adequatc Hcalth Program. 59 YALE L.J. 292 (1950). See also 139 JAMA 1005 (1949).

614. See Davis, America Organizes Medicine 174-5 (1941).

615. The NPC was formed in 1939 as a nominally independent group due to the fear that the AMA was prevented from extensive lobbying by its charter as a non-profit organization. 22 Minn. Med. 842-3 (1939); 3 Conn. State Med. J. 685 (1939). Both the public and the profession considered the NPC as a front for the AMA. Whitman, Doctors in an Uproar, Collier's, May 14, 1949, p. 21 (citing, inter alia, demands by physicians that the AMA sever its connections with NPC). See also Fishbein, The Public Relations of American Medicine, 130 JAMA 509, 512-13 (1946).

616. See 139 JAMA 924 (1949); 139 JAMA 1276 (1949).

617. Whitman, supra note 615 (2 past presidents and a former AMA trustee headed the NPC).

618. See, e.g., address of the President of the Arkansas Medical Society to the state House of Delegates, reprinted in 34 J. ARK. MED. Soc. 15 (1942): "I have repentedly" stressed the fact that each physician in our state should affiliate with the work of the National Physicians Committee. ..." See 37 Rocky Mountars MEv. J. $15-16$ (1940); 22 Minn. MEd. 842-3 (1939) ; 39 NoRthwest MEd. 3 (1940) (editorials urging members to contribute to NPC). See also NPC, Outuine Method of Planned Action (1941) (reprinting letters from county societies tendering donations to NPC or indicating assessment of members by the society for NPC support). 
dresses, to editorials in the Joumal, resolutions in the House of Delegates, and testimony before legislative committees.

The NPC undertook organized medicine's first concerted effort to influence public opinion. Working largely through doctors, the Committee is reported to have distributed 25 million pamphlets. ${ }^{610}$ But the occasional crudeness of its methods reduced its effectiveness. In 1948, the press protested the NPC's "attempt to buy editorial opinion" through a $\$ 3000$ prize offered for the best published anti-national health insurance cartoon. ${ }^{620}$ And when the NPC distributed copies of a letter signed by "Reverend" Dan Gilbert, Editor of the notorious Defender and former associate of Silver Shirt Gerald W'inrod, severe criticism from AMA members followed. ${ }^{021}$ By the end of 1948 the NPC's utility as a rallying point for organized medicine was negligible. 222

Similarly, Dr. Morris Fishbein, Editor of the Journal and the recognized spokesman for organized medicine had become the "symbol of old reactionary leadership" in the profession, at a time when favorable public opinion was becoming increasingly important. ${ }^{623}$ The ANIA's decision in 1946 to hire a special public relations counsel was an important step officially taken to curtail Fishbein's activities. ${ }^{624}$ Finally, in 1949, the Board of Trustees announced the "retirement" of Dr. Fishbein after thirty-seven years of "devoted service." 625

By the end of 1948 it was apparent to AMIA leadership that a more positive and drastic program was needed to forestall the enactment of compulsory

619. 96 Cong. Rec. 13914 (1950). See, c.g., National. Pursictins Co:mitmee, Abolishing Private Miedical Practice, os $\$ 3,04 \$, 000,000.00$ of Political Aiemicise. YeArly IN the United States (1943). This pamphlet, originally issued in 1943, see test at note 602 stipra, was again distributed in 1944. Mrore than a million copies of a sispage flyer called "Political Medicine-You can Stop It" were circulated. Fishn, Phy"sicians Fight Truman Health Plan, Christian Science Afonitor, Dec. 22, 1945, p. 3, cols. 6 -S. The National Physicians Committee spent $\$ 353,390$ during the first nine months of 1948 , more than any other registered lobby during that peried. Of this sum, $\$ 122,000$ was received from twenty-nine drug manufacturers. $A M A$ Lobby Group to be Liquidalcd, N.Y. Times, April 17, 1949, p. 34, col. 1.

620. 96 CoNG. Rec. 13914 (1950).

621. The Joumal officially disavowed the Gilbert letter and all advance knowledge of its circulation and declared that the AMIA "does not require allies of doubtiul repute." 139 JAMIA 924 (1949).

622. Ibid. (editorial praising NPC but indicating that the ANA is prepared to talie up its own burden). The NPC had already agreed to cease activities and liquidate as soon as practicable. N.Y. Times, April 17, 1949, p. 34, col. 1.

623. See Mayer, The Rise and Fall of Dr. Fishbcin, Harper's, Nov., 1949, p. 76.

624. See N.Y. Times, July 3, 1946, p. 23, col. 7; Bostón Daily Globe, Sept. 26, 1946.

Prior to 1946, there had been indications of organized medicine's discontent with Dr. Fishbein. See, e.g., Chicago Daily Times, May 19, 1938 (New Jersey Medical Suciety resolution seeking to confine the writings of Dr. Fishbein to the Joumal); Deutsch, California Doctors Denand Dismissal of Dr. Fishbcin, PM, MIay 11, 1944 (resulution of California Medical Association demanding Dr. Fishbein's resignation on the grounds that he was "detracting from the dignity of the profession.").

625. N.Y. Times, Dec. 7, 1949, p. 33, col. 8 . 
health insurance. The Ewing Report, followed by the Democratic victories in the fall, increased the likelihood that Congress would pass a national health program. Moreover, the new British experiment in socialized medicine had fostered public interest and discussion concerning the adoption of a similar program in the United States. The discrediting of The National Physicians Committee and the retirement of Dr. Fishbein cleared the road for new, more effective opposition techniques.

The interim session of the House of Delegates convened in St. Louis the month following the November elections "in a spirit of great urgency." The delegates voted to assess each AMA member $\$ 25$ to build a $\$ 3,500,000$ "political war chest to fight socialized medicine."627 Despite considerable adverse criticism from members ${ }^{628}$ the AMA went ahead with plans for an enlarged Washington office and an advertising campaign to "educate" the American people. ${ }^{629}$ And it soon announced that its "National Education Campaign" would be conducted by the public relations firm of Whitaker \& Baxter. ${ }^{630}$

The experts whom the AMA chose to lead its campaign were already well known for their successes in California politics. ${ }^{631}$ Chief among these was their victory, on behalf of the California Medical Association, over Governor Warren's proposal for state-wide compulsory health insurance. ${ }^{632}$ Whitaker \& Baxter were called in immediately after Governor Warren announced his legislative program in January, $1945 . .^{633}$ In accordance with the procedure they had evolved for short, urgent campaigns they "started at the top and worked down." 634 They obtained public endorsement from the leaders of more

626. N.Y. Times, Dec. 3, 1948, p. 20, col. 5.

627. N.Y. Times, Dec. 2, 1948, p. 32, col. 2 ; id., Dec. 3, 1948, p. 20, col. 1.

628. See, e.g., 138 JAMA 1230 (1948); 139 JAMA 532 (1949) (letter of protest from 148 doctors).

629. See 139 JAMA 532 (1949) (reply to letter of protest, asserting that assessment funds to be used for educational purposes, not as "slush" fund). See also 138 JAMA 1098 (1948) ("The fund thus provided will be used for a nationwide plan of eduction on the progress of American medicine, the importance of the conservation of health and the advantages of a high quality of medical care.").

630. 138 JAMA 1230 (1948).

631. Williams, Government by Whitaker and Baxter, $I$, The Nation, April 14, 1951, p. 346.

632. The Warren plan envisioned a compulsory health insurance program providing statewide medical, dental, and hospitalization service. The program was to be funanced by a three percent payroll tax on the first $\$ 4000$ of income, divided equally between cmployer and employee. Coverage was extended to all private and public employees and their dependents-generally, those covered by the California Unemployment Insurance Act. An eleven-man directorate would be composed of three each from employers, cmployees, and physicians, one dentist, and the State Director of Public Health. Sec Sartain, California's Health Insurance Drana, 34 Survey Graphic 440 (1945); N.Y. 'Times, Jan. 21, 1945, p. 34, col. 7.

633. Williams, supre note 631.

634. They had only three months in which to defeat the bill before a vote was scheduled. Whitaker, Medical Public Relations and Governuent 3 (reprint of address before the California Medical Association, Nov. 27, 1948). 
than one hundred state organizations, enlisted the support of more than two hundred newspapers, made speeches to some nine thousand physicians, and induced doctors, druggists, insurance executives, and dentists to speal: to hundreds of "thought leaders." 335 A state-wide "Voluntary Health Insurance Week" promoted membership in the society sponsored California Physicians Service. ${ }^{636}$ Medical groups bought forty thousand inches of paid advertisements, and sympathetic merchants, another thirty thousand. ${ }^{037}$ At the end of three months, Warren's bill was defeated by one vote. ${ }^{.38}$ In 1947 a similar bill failed by a wider margin, and today, state health insurance is given little or no chance of passage in California. ${ }^{630}$

The Chicago office of the AIIA's National Education Campaign, with a staff of thirty-seven, was established in January, 1949. To overcome opposition from within the profession to the Campaign and its $\$ 25$ assessment, ${ }^{\text {, }}$ public speaking tours and circulars were successfully employed ${ }^{\circ i 1}$ and intense doctor support was stimulated. During the first year of the Campaign all but a few members displayed posters and nearly 20 million pamphlets were distributed to patients; ${ }^{642}$ Congressmen were contacted by their personal physicians and urged to support AMIA views. ${ }^{\text {of }}$ A Campaign "Blueprint" published in February 64 indicated that the first year's strategy would be to

635. Ibid. These "thought leaders" consisted of the presidents of 400 civic clubs, 280 officers of veterans organizations, 500 women's club officers, 200 insurance esceutives and public officials throughout the state. Wiliams, Gozernment by Whitalecr and Baxler, II, The Nation, April 21, 1951, p. 366.

636. WHITAKER, op. cit. supra note 634 .

637. Ibid.

638. Williams, supra note 635 , at 368 .

639. Ibid.

640. See note 628 suspra. Both N'ew York and Kings County Medical Socictics roted to oppose the assessment, N.Y. Times, Feb. 16, 1949, p. 15, col. 1; id., Mar. 1, 1949, p. 27, col. S, although the former group later reversed itself, id., Mar. 29, 1949, p. 21, col. 1. See also 240 N. ENG. J. MED. 587 (1949) (reporting that only 2300 [of 6600] members of the MIassachusetts Medical Society had paid by April, 1949).

641. By December, 1949, S0\% of ANIA members had paid the assessment. N.Y. Times, Dec. 7, 1949, p. 33, col. \&. But see 241 N. ENG. J. MFE. 389 (1949) (indieating that in Massachusetts only $49 \%$ had paid by September, 1949, and that there were eleven other states with even lower percentage figures).

642. AMA, The 1949 Canpaign Refort by the Coosninating Cosamtree 7 (1949).

The wives of physicians were also mobilized. A pamphlet, distributed through wumen's auxiliaries, advised the doctor's wife to play a part in the campaign. She was instructed to keep her "husband's office . . . supplied with campaign literature," to "tucls pamphlets into all her personal correspondence-even invitations to dinner parties," and warned that "[d] ebates are for experts only." AMA, Ir's Your Crusane Too! 7-9 (1949).

643. The Doctor in Politics, Consumer Reports, Feb., 1950, pp. 75-6. Representative John Dingell of Michigan, a proponent of the federal program, called this technique, "talsing advantage of a special confidential relationship to lobby." N.Y. Times, May 21, 1949, p. 28 , col. 1.

644. Whitaker \& Baxter, A Starplifted Blueprint of tae Caspatg: Agal:st Compulsory Health Insurance (1949) (cited throughout as Bruenri:ix). 
mobilize lay group leaders who, in turn, would urge the membership of their groups to back the AMA in communications to legislators. ${ }^{645}$

By December, 1949, the National Education Campaign Headquarters reported that it had the public endorsement of 1829 separate organizations ranging in size from a few to more than five million members. ${ }^{040}$ In addition nearly 55 million pieces of literature had been distributed to an estimated 100 million people at a cost of more than $\$ 1,000,000 .^{647}$ Traveling press representatives and selected spokesmen operating through "Speakers Bureaus," and 250,000 physicians, druggists, and insurance men under less formal organization, had spoken, written, and distributed AMA material. ${ }^{648}$ Half of the first year's budget was allocated to "defense and attack," the other half to "extending and improving the services of the voluntary health insurance system." 649 The latter was to be organized medicine's affirmative answer to the Ewing program. ${ }^{650}$ Insurance companies ${ }^{651}$ and doctors were urged to promote the sale of voluntary health insurance policies under the slogan "The Voluntary Way is the American Way." ${ }^{652}$ The rate of enrollment in 1949 was nearly one million each month. ${ }^{653}$

The National Education Campaign soon produced a marked effect. Former congressional supporters of the President's plan in Congress began to withdraw their backing, and by November many sponsors conceded that there was no hope of enacting any health insurance law in the first session of the EightyFirst Congress. ${ }^{654}$

645. Id. at 3. See Whitaker, The National Education Caupaign of the AmerlCan Medical Association 6 (Address delivered before the Council of the New England State Medical Societies, March 27, 1949, mimeo. copy on file in Yale Law Library) : "The fastest way to make our influence felt in Washington is to marshal a powerful array of Nation-wide organizations, representing great groups of American citizens, in opposition to compulsory health insurance."

Once representatives of organized medicine secured the endorsement of a group they were urged to send copies of the resolution to their Senators, Congressmen, State Legislators, the AMA, and the National Education Campaign Directors. BAXTER, WHAT WiLr. We Do with THE Docror's \$25, pp. 9-10 (1949) (Address delivered before the Conference of State Medical Societies, Feb. 12, 1949, mimeo. copy on file in Yale Law Library).

646. AMA, 1949 Canspaign Report by the Coordinating Conmittee 3-4 (1949).

647. Whitaker, Professionat Political Campaign Mnamagenent 3 (Address delivered before the Public Relations Society of America, Dec. 5, 1949, reprint on file in Yale Law Library).

648. Ibid.

649. Baxter, Public Retations' Precocious Baby-Professional. Political Campaign Matagement 4 (Address delivered before the Public Relations Society of America, Dec. 5, 1949, reprint on file in Yale Law Library).

650. BLUEPRINT 1,3 .

651. See The Doctor in Politics, Consumer Reports, Feb., 1950, pp. $75-7$ (group of commercial insurance companies plan to aid the AMA Campaign).

652. Another popular slogan of the National Education Campaign was "Guard your health-Guard your pocketbook-Socialized Medicine would rob both."

653. AMA, 1949 Camipatgn Report by the Coordinating Committee 13 (1949).

654. Morris, Sponsors Abandon Early Health Bill, N.Y. Times, Oct. 27, 1949, p. 28, col. 4. 
Realizing that its 1949 success provided only temporary respite, organized medicine planned its 1950 Campaign to end conclusively the threat of national health insurance. ${ }^{655}$ The House of Delegates, in December, 1949, voted to impose permanent yearly dues of $\$ 25$ for all AMIA members. ${ }^{600}$ There vere "fringe bills" to defeat ${ }^{657}$ and, most important, there was a decisive congressional election to be won. . $^{65}$

Much of the strategy of the 1950 Campaign was a continuation of the previous year's Blueprint. ${ }^{659}$ Furthermore, an intensive two-week advertising campaign was timed to influence the congressional elections. ${ }^{\text {c60 }} \$ 1,100,000$ was set aside ${ }^{601}$-one-half for newspaper advertisements and the remainder equally divided for radio time and magazine space-to arouse public opposition to compulsory health insurance. ${ }^{662}$

Since the AMA could not openly endorse any candidates, ${ }^{\mathrm{c} 63}$ it urged in-

655. AliA, 1949 Cajpaign Report by the Coondnativg Cosmitmee 20 (1949).

656. N.Y. Times, Dec. 9, 1949, p. 25, col. 1.

657. Whitaker, Miedicine's Road Ahead: Part 2-Casipaga: Stmategy n:id Policies 2-3 (Address delivered before AMIA Second National Conference on the National Education Campaign, Feb. 12, 1950, mimeo. copy on file in Yale Law Library) (listing federal aid to medical education, the sickness-disability provisions of Social Security proposals, and school health legislation as "the entering wedge for socialized medicine").

658. Id. at 4 .

659. Baxter, Miedictne's Road Ahead: Part 1-Casipaygri Onjectives aido ProCEDURes (Address delivered before AMA Second National Conference on the National Education Campaign, Feb. 12, 1950, mimeo. copy on file in Yale Law Library). For additional education techniques employed see 144 JAMTA 46 (1950) (comic book, "The Sad Case of Waiting Room Willie," originated by Baltimore Mredical Society and later distributed nationally); Detar, The Country Doctor Answers the Ewrig Reforr (Mich. Med. Soc. 1950) (Pamphlet equipped with index-like code; a speaker, by referring to this code, deciding how long he is to speak and to what general type of interest group, is told what paragraphs of the pamphlet to paste together as the basis for his talli.).

660. 143 JAMA 744 (1950).

661. Anspacher, AMA Maps Ad War on Socialized Medicine, San Francisco Chronicle, June 27,1950, p. 2.

662. During September the AMA bought advertising space in trade publications urging sympathetic business organizations to support the AMA's October campaign by purchasing tie-in ads, for the purpose of which ready-made mats were available at the AMCA's campaign headquarters. More than one hundred banks, several insurance companies, utilities, druggists, and other groups underwrote such ads to the extent of $\$ 2,000,000$. Stokes, Doctors of Politics, N.Y. World Telegram, Oct. 1, 1950, \$2, p. 1, cols. 1-3. In the appointed week of October 8 , every bona fide weekly and daily newspaper in the United States-10,033 in all-carried a five column by fourteen inch advertisement from the AMIA. Sixteen hundred radio stations broadcast spot-commercials and thirty-five magazines carried campaign copy. N.Y. Post, Oct. 23, 1950, p. 4, col. 1. At least half of the nation's newspapers had sold tie-in ads, as had an equal fraction of radio stations. 144 JAMA 767 (1950). In addition state and local medical societies bought advertisements with their own funds. Massachusetts Medical Society, for example, bought an entire cignt page insert section of the Boston Post. The section consisted of advertisements and articles testifying to the advances of American medicine under non-compulsory, non-governmental direction. Boston Post, Oct. 11, 1950, pp. 33-40. So vast was the total advertising schedule that four major agencies combined to handle the complex arrangements. N.I. Times, Nov. 26, 1950, p. 9, col. 2.

663. The Campaign directors distributed a memorandum prepared by a Chiago law 
dividual members to engage in political action supplementary to the National Education Campaign. ${ }^{.04}$ Member doctors formed Healing Arts or MedicalDental Committees to help defeat supporters of national health insurance. Previous experience in special elections had demonstrated the effectiveness of such committees. During the 1949 election in the 26th Pennsylvania Congressional District, the Healing Arts Committees mailed more than 190,000 letters, made more than 120,000 personal telephone calls, placed a series of twelve advertisements in every newspaper in the District, and purchased radio time to urge the election of John P. Saylor and the defeat of his Democratic opponent, who had endorsed the President's program. The total vote approached the District's turnout for the 1948 presidential election and more than 20,000 Democrats switched their votes to elect Saylor. ${ }^{.00}$

During the 1950 campaign, doctors in many congressional districts formed their own political committees. In Wisconsin, the Physicians for Freedom helped to defeat Representative Andrew Biemiller through posters, advertisements, and campaign literature included with monthly bills to patients. ${ }^{607}$ In Florida, similar tactics were used against Senator Claude Pepper in his unsuccessful bid for renomination. Tallahassee hospital patients received breakfast trays upon which were placed cards reading, "This is the season for canning Pepper." 608 And in Ohio the Physicians Committee for Taft was politically active in enlisting support. ${ }^{609}$

firm containing a detailed summary of laws relating to the participation of doctors and medical societies in political affairs. The fundamental principle stressed was that doctors engaging in active support of a candidate must do so as individuals, for the AMA and its societies may not legally endorse or contribute funds to any candidate, use medical socicty letterheads or facilities on his behalf, sign an advertisement that endorses him, or sponsor any advertising on his behalf. Kirkland, Fleming, Green, Martin \& Ellis, Inter* pretation of Laws Governing Participation in Election Campatgns (1950).

664. WHITAKeR, sipra note 657, at 6-14.

665. Cunningham, Can Political Means Gain Professional Ends?, Modem Hospital, Dec., 1951, p. 51; The Doctor in Politics, Consumer Reports, Feb., 1950, p. 75 ; QuestronNAIRE No. 80 (several state medical societies reporting formation of local Healing Arts Committees in their areas).

666. The story of the campaign and the role of the Healing Arts Committee is related in Cunningham, supra note 665 . The local Cambria County Medical Society officially endorsed the candidacy of Congressman Saylor; this practice was apparently abandoned following the publication of the legal memo relating to participation in political campaigns. See note 663 supra.

During the same special election year, similar tactics were employed without success on behalf of John Foster Dulles in his senatorial contest with Senator Ferbert Lehman. Cunningham, supra note 665 .

667. N.Y. Post, Oct. 24, 1950, p. 35, col. 1.

668. Cf. The Doctor in Politics, Consumer Reports, Feb., 1950, pp. 75-6; see note 132 supra. Dr. Elmer Henderson, Chairman of the AMA's National Education Campaign Coordinating Committee, stated that "doctors, acting as individuals, were in large mersure responsible for the recent defeat of Senator Claude Pepper in Florida and were a major factor in the defeat of Senator Frank Graham in North Carolina." San Francisco Chronicle, June 27, 1950, p. 2.

669. N.Y. Post, Oct. 24, 1950, p. 35, col. 2. 
The National Education Campaign and the Healing Arts Committees were rewarded by the election returns. Some of national health insurance's most active supporters were defeated. The president of the AMA called the results "very reassuring"670 and announced to the House of Delegates that in the light of the recent campaign "any compulsory health insurance bill in Congress today would go down to defeat by at least a 2 to 1 vote."

Despite the fact that national health insurance seems a dead issue, organized medicine has maintained a continuing interest in political affairs. Democratic platform in 1952 made no mention of national health insurance. Governor Stevenson stated his opposition to such a plan but commented on the need for assistance in financing the costs of illness. ${ }^{673}$ The Republican platform unequivocally stated opposition to federal health insurance and General Eisenhower left no doubt that he was opposed to "socialized medicine." crs A non-partisan organization, ${ }^{675}$ the AMA took no official sides. But by October a "National Professional Committee for Eisenhower and Nixon" was mailing letters from the National Education Campaign's former address, urging that medical and related groups support the Republican ticket. The letterhead featured the names of former AMIA Presidents Henderson as chairman, and Cline and Irons as vice-chairmen, as well as Whitaker \& Baxter. ${ }^{670}$

Since the defeat of the Truman-Ewing plan, controversy concerning the role of the Federal Government in the health insurance field has centered around proposals to aid voluntary projects. The Mlagnuson Report, ${ }^{677}$ pre-

670. N.Y. Times, Nov, 26,1950 , p. 9, col. 2.

671. 144 JAMA 1269 (1950).

672. The Joumal warned that national health insurance might yet be revived by Congress. 144 JAMA 1186 (1950). However, Representative Dingell's mational health insurance bill in the $\$ 2 d$ Congress never came out of committee. H.R. 54, 82d Cong., 1st Sess. (1951). See Brown, Voluxtary or Conipulsory Healtu Insurazice 6-14 (1952).

673. See Modern Medicine, Nov. 1, 1952, pp. 57-8.

674. Ibid.

675. The AMIA consistently asserted its non-partisanship. See, e.g., 147 JAMA 1362 (1951) (AMA House of Delegates to hear discussion of major national issues by representatives of both parties-Senators Rohert A. Tait and Harry F. Byrd).

676. Copy of circular letter on file in Yale Lav Library. The "Physicians for Stevenson" group had no similar former AMIA officialdom amung its sponsorship. See N.I. Times, Oct. 28,1952 , p. 25 , cols. 48 .

677. President's Conmission on the Healtu Needs of the Nation, Bundiac AxIERICA's Healte (1952-53) (cited throughout as Misantson Rep.).

President Truman appointed this commission late in 1951 to make a study of Amerien's "total health requirements" and to recommend courses of action to meet these needs. N.Y. Times, Dec. 30, 1951, p. 1, col. 2. Paul B. Magnuson, M.D., Chairman, is a Profiessor Emeritus at Northwestern University Mfedical School, and was formerly Mfedical Direetor of the Veterans Administration. Other members included Chester I. Barnard, Chairman, National Science Foundation; a college president; one medical school dean and four distinguished physicians; two dental college deans; and representatives from nursing, labor, farming, and consumers' organizations. One AMIA Trustee hastily declined his appointment and called the Commission an "instrument of practical politics." 14S JAMIA 208 (1952). See also Leviero, Health Program a Campaign Issuc, N.I. Times, Jan. 20, 1952, $\$ 4$, p. 6, cols. 1-3. The House of Delegates later characterized it as "politieally inspired." Id., June 11, 1952, p. 20, col. 3. See also Lewis, A.MA Splits Ozcr Hcalls 
pared by President Truman's Commission on the Health Needs of the Nation, recommended federal grants to subsidize either these plans or potential subscribers having low incomes. ${ }^{678}$ In a 1954 Message to Congress, President Eisenhower advocated a different measure: federal "re-insurance" of voluntary plans. ${ }^{679}$ At present, most voluntary schemes place a limit upon the protection given their subscribers. ${ }^{680}$ This leaves the cost of catastrophic illness to be borne largely by the individual. Under re-insurance the Federal Government, in return for premiums received from the plans, would insure against claims over a certain figure so that coverage could be extended to include high-cost services. ${ }^{681}$ The AMA opposed the Magnuson recommendations because they called for Government subsidies. ${ }^{682}$ They have similarly condemned re-insurance, fearing that it might lead to subsidization and constitute an "opening wedge to socialized medicine."

Throughout its recent campaign to halt governmental inroads into medical affairs the AMA has adopted an essentially emotional approach. The basic issues are obscured by the AMA's use of catch-phrases, like "socialized medicine," and such devices as mass distribution of the famous Sir Luke Fildes painting, "The Doctor," captioned "Keep politics out of this picture." Organized medicine's counterproposals, advocating local controls or private, voluntary remedies, often provide inadequate or partial solutions. By presenting the profession's views realistically, the AMA's campaign against Government health programs could lead to enlightened discussion of the merits rather than exchange of invective.

\section{Limitations on AMA Power}

No other voluntary association commands such power within its area of interest as does the AMA. It holds a position of authority over the individual doctor, wields a determining voice in medical education, controls the conditions of practice, and occupies a unique position of influence in shaping government health policies. Despite the dangers inherent in such a concentration of power, no interest group enjoys more freedom from formal control than organized medicine. The individual physician, subjected to disciplinary attthority of the medical society in his local community, has little redress outside the framework of organized medicine. Courts, comparing society member-

Commission, Medical Economics, July, 1952, p. 117. But see 246 N. ENG. J. MEv. 73 (1952): "The appointment of a well balanced, unprejudiced commission to study the health needs of the nation is a logical way of bringing further emphasis to bear on the problem. The President is to be congratulated on his determination to seck expert advice, and he should receive the fullest co-operation from organized medicine."

678. 1 Magnuson Rep. 47-8.

679. N.Y. Times, Jan. 19, 1954, p. 1, col. 8.

680. See note 406 supra and accompanying text.

681. N.Y. Times, Jan. 11, 1954, p. 10, col. 3 ; id., Jan. 19, 1954, p. 1, col. 8; id., March 12, 1954, p. 1, col. 8 .

682. Dickinson, Building Health by Commission, 151 JAMA 1032-7 (1953) ("Taken as a whole, this Report should be filed away in the archives marked, 'Creeping Socialism." ").

683. See, e.g., N.Y. Times, Jan. 24, 1954, § 4, p. 2, col. 5 ; id., Jan. 30, 1954, p. 8, col. 5. 
ship to affiliation in fraternal or benevolent organizations, ${ }^{\text {,9s }}$ find that expulsion or denial of membership deprives the doctor of no property right, and are reluctant to interefere unless the society's own prescribed formalities were not observed. ${ }^{\text {sse }}$ Even if the scope of judicial review encompassed an examination of the merits, and resulted in admission or reinstatement of unreasonably disciplined physicians, the remedy might still be of little use. Legal process cannot prevent informal sanctions and ostracism. And within the framework of organized medicine, the doctor who challenges AIIA authority to determine his method of practice is tried and judged by his fellow physicians who may have an economic interest in proscribing his allegedly offensive conduct. ${ }^{\text {esz }}$

Moreover, while the disapproved prepaid medical service plan is better able to cope with some of organized medicine's weapons, the legal protections available to it are probably inadequate. True, in American Mcdical Associalion v. United States, ${ }^{\mathrm{CBS}}$ the Supreme Court held organized medicine in violation of the Sherman Act for its conspiracy to destroy Group Health Association in Washington, D.C. ${ }^{6 s 9}$ The Court viewed the furnishing of prepaid health services as a trade or business within the scope of the antitrust laws. ${ }^{630}$ It found the conduct of Group Health doctors to be prohibited by the Principles of Medical Ethics, ${ }^{691}$ but refused to give legal status to the Principles by holding that the societies' attempt to enforce them constituted a restraint. However, the Government was not required to show an effect upon interstate commerce; this case was brought under the Sherman Act's Section $3{ }^{, 092}$ which regulates activities within the District of Columbia.

684. See, e.g., Smith v. Kern County Medical Ass'n, 19 Cal.2d 203, 120 P.2d 874 (1942) (refusal to review medical society expulsion, court relies upon Levy v. Magnolis Lodge, I.O.O.F., 110 Cal. 297, 42 Pac. 887 (1S95)) ; Medical Society of Mobile County w. Walker, 245 Ala. 135, 16 So.2d 321 (1944) ; Brown v. Harris County Aredical Society, 194 S.W. 1179 (Tex. Civ. App. 1917).

685. E.g., Smith v. Kern County Medical Ass'n, supra note 684; Weyrens v. Scotts Bluff County Medical Soc., 133 Neb. 814, 817, 277 N.W. 378, 379 (1938) (expulsion from medical society resulting in denial of hospital privileges and loss of income held no deprivation of property right). But of. Reid v. Medical Society of Oneida County, 156 N.Y. Supp. 780, 783 (Sup. Ct. 1915).

686. Smith v. Kern County Medical Ass'n, supra note 6S4; Ewald v. Medical Society of the County of New York, 144 App. Div. \$2, 128 N.Y. Supp. 886 (1st Dep't 1911) ; Reid v. Medical Society of Oneida County, sipra note 685; Brown v. Harris County Mfelical Saciety, supra note 684 .

687. "A physician may be brought up for discipline before a committee of doctors that might include his chief competitors in his private practice. In uur civil or criminal courts we would not tolerate a situation in which the judges might profit financially as a result of the verdict they rendered. We should not permit such a situstiun to exist in medicine." Letter from Thurman Arnold, Esq., to Channing Frothingham, MI.D., dated July 2, 1947, copy on file in Yale Law Library).

688. 317 U.S. 519 (1943), affrming 130 F.2d 233 (D.C. Cir. 1942).

689. For the facts of this controversy, see text at notes $421-1$, sizpra.

690. United States v. American Medical Association, 317 U.S. 519, 528 (1943).

691. Id. at 526 .

692. 26 Stat. 209 (1890), 15 U.S.C. $\$ 3$ (1946). 
United States v. Oregon State Medical Society ${ }^{603}$ demonstrates the practical difficulty of such an action under Sections 1 and 2. There, non-medical society plans and organized medicine had been engaged in a bitter "tooth-andclaw struggle." 694 One charge, alleging a conspiracy to restrain competition between several medical society sponsored plans, was dismissed because these plans did not operate across state lines. ${ }^{606}$ The other charge, alleging conspiracy by organized medicine to destroy private plans which were operating across state lines, was dismissed for failure of proof, thus avoiding the necessity for deciding the question of interstate commerce. ${ }^{606}$ Even if interstate commerce had been involved here, the Commerce Clause remains an obstacle to Sherman Act relief; practically all other private plans operate within the confines of a single state. Local sponsorship of such groups plus variations in restrictive state medical service acts have prevented expansion into neighboring states.

Actions such as Group Health Cooperative of Puget Sound v. King County Medical Society, ${ }^{607}$ brought under the Washington State Constitution, ${ }^{008}$ do not encounter this problem. However, state courts may not construe antimonopoly provisions as broadly as did the Washington Supreme Court.000 And, most important, in a majority of states medical societies have obtained restrictive legislation which makes their plans legal monopolies. ${ }^{700}$

Perhaps the major obstacle to antitrust prosecution under either state or federal law is the difficulty in proving a conspiracy. The District of Columbia and Washington State cases were characterized by such acts as expulsion and denial of hospital facilities. ${ }^{701}$ But in the Oregon case, medical societies had abandoned such tactics in 1941, seven years before the action was brought.702 Recently, organized medicine has conveyed veiled threats to doctors participating in disapproved plans by outspoken condemnation of such plans in ethical terms. ${ }^{703}$ Such indirect, less overt opposition probably discourages physicians from affiliating with disapproved plans, ${ }^{704}$ but is less susceptible to antitrust prosecution.

Perhaps a more effective limitation on the power of organized medicine

693. 343 U.S. 326 (1952), affirming 95 F. Supp. 103 (D. Ore. 1950).

694. Id. at 329 .

695. Id. at 338 .

696. Id. at 329-37.

697. 39 Wash.2d 586, 237 P.2d 737 (1951).

698. Art. XII, $\S 22$ : "Monopolies and trusts shall never be allowed in this state, and no incorporated company, co-partnership, or association of persons in this state shall directly or indirectly combine or make any contract ... for the purpose of fixing the price or limiting the production ... of any product or commodity. ..."

699. Group Health Cooperative of Puget Sound v. King County Medical Society, 39 Wash.2d 586, 634-45, 237 P.2d 737, 763-9 (1951).

700. See notes $437-42$ stura and accompanying text.

701. See notes 422, 425, 429 sttpra and accompanying text.

702. United States v. Oregon State Medical Society, 343 U.S. 326, 329-30 (1952).

703. See, e.g., note 468 supra.

704. 1 Magnuson REP. 34. 
stems from developments in medical technology and public demand for more medical care. The growth of group practice has been inevitable, despite AMA discouragement, because of advances in medical science, increased specializztion, and interdependence among doctors. And increased public awareness of the necessity for more frequent and complete medical attention has created an incentive to provide medical services under systems which encourage lower costs, facilitate budgeting, and utilize governmental assistance. These tendencies constitute an underlying limitation on organized medicine's ability to control the development of medical practice.

\section{CONCLUSION}

To protect the individual doctor from unreasonable exercise of organized medicine's authority, the crucial importance of society membership should be deemphasized. This approach would mitigate the severe consequences of the medical society's disciplinary powers. Dissident physicians might better be able to resist AMA views if, for example, government and specialty board appointments were not dependent upon membership. The societies' power to punish serious medical offenses would be weakened, but the Medical Practice Acts can afford the public adequate protection. And revocation or suspension of licensure, unilike medical society disciplinary action, is subject to the impartial scrutiny of judicial review.

Perhaps the most effective method of deemphasizing membership would be to insure availability of hospital privileges to non-members. Montana has achieved this through legislation prohibiting discrimination by hospitals against any licensed physician. ${ }^{05}$ If he is qualified to practice under state law, the Montana doctor may send his patient to any hospital. This type of provision might require qualification in teaching hospitals ${ }^{700}$ and in urban areas where variations in the desirability of hospitals would necessitate some limitation on use of facilities. ${ }^{707}$ However, its primary effect is to remove organized medicine's coercive power over doctors without impairing professional standards.

Secondly, to promote greater responsiveness to the public's medical requirements, organized medicine should be divested of its control over the nation's supply of doctors. Presently the AMIA sets educational standards and the state societies dominate licensing boards. It is desirable that agencies composed of physicians control qualifications for admission. But organized medicine's resulting power over supply can be diminished without sacrificing the quality of a doctor's training. Existing high AMIA standards, combined with lack of funds, impose a practical limitation upon the number of MI.D.'s graduated each year. The doctor supply, so crucial to the nation's well-being, should not hinge upon the financial condition of medical schools. Federal aid

705. Rev. Codes Mont. $\$ 69-2917$ (1947).

706. Those hospital wards used by medical schools for teaching purposes must be staffed only by the most qualified physicians. See Mewars, Docturs, Peurle, .1:id Goier:MIENT, c. 3 (1953).

707. In order to insure an even distribution of doctors among all hospitals in a community, some neutral agency must have power to prevent werstafing of certain hospitals. 
to medical education would help divorce the size of classes from standards of quality. AMA power to set educational requirements and to inspect schools would not be impaired. But the public's need for physicians, rather than financial considerations, would determine our doctor resources.

Organized medicine also exercises quasi-legal authority over the formation of health insurance plans. To foster the development of new methods for providing low-cost prepaid care, legislatures should divest the state societies of this control. State statutes requiring approval or participation by the medical society or a majority of doctors have foreclosed experimentation in solving pressing medico-economic problems. No existing plan, irrespective of sponsorship, satisfies all requirements. Variations among the needs and financial capacity of medical consumers necessitate different types of practice, coverage, and sponsorship. While indemnity insurance against hospitalization and surgical costs may be adequate for some, comprehensive coverage under group practice may be highly desirable for others. Independent groups of doctors, cooperatives, unions, and employers-as well as the medical societies-should be free to work out their own solutions. Governmental assistance to plans or low-income subscribers may also be required.

The Illinois Voluntary Health Services Plans Act of $1951{ }^{708}$ is a unique example of progressive health insurance legislation. This statute enables the formation of non-profit medical service plans under consumer sponsorship. Thirty percent of the trustees of such groups must be licensed physicians; doctor representation is assured but lay control is permitted. Group practice is facilitated because there is no requirement that all or a majority of doctors in the area participate. The Illinois State Medical Society assisted in securing the passage of this legislation. ${ }^{709}$ But other medical societies have not been so forward-looking.

Finally, there is a range of activity which external restraints upon organized medicine cannot reach. Certainly no legislation can require the AMA to provide a forum for dissenting opinion. But so long as conflicting viewpoints are sidetracked at the lower levels and denied space in the Journal, the AMA cannot accurately claim to speak for the profession. Similarly, no legislation can prevent organized medicine from prejudging new ideas and disparaging them in evasive ethical terms. In the past, the AMA has condemned as unethical various medical practices which it now approves and advocates; the "Principles," as interpreted by the medical societies, are not unchanging. And until organized medicine meets questions of medical economics in terms of the real issues, it will not contribute to the solution of current problems. New ideas which the Association has accepted have been forced upon it; by assuming leadership in experimentation with unproved systems of practice and payment, the AMA could become an instrument of progress.

708. Ill. Rev. Stat. c. 32, \$599 et seq. (Supp. 1951). See Frey, Expanding Privalc Health Service Programs in Illinois, 34 ChICAgo Bar Recond 295 (1953).

709. Illinots QUestionnaIRE No. 78; Cooperative Health Federation of America Information Letter, Vol. IV, No. 7, Nov.-Dec., 1950. The State Medical Society of Wisconsin, too, has helped procure liberalization of restrictive enabling acts. Ibid. 